\title{
Attitudes towards and use of ebooks at the University of Canterbury
}

by

\section{Nick Scullin}

\author{
Submitted to the School of Information Management, \\ Victoria University of Wellington \\ in partial fulfilment of the requirements for the degree of \\ Master of Information Studies
}




\section{Contents}

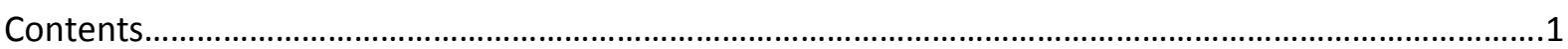

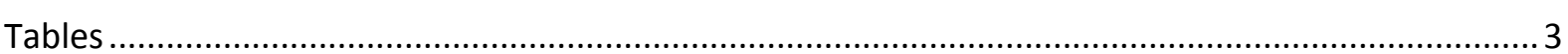

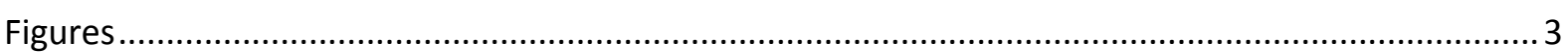

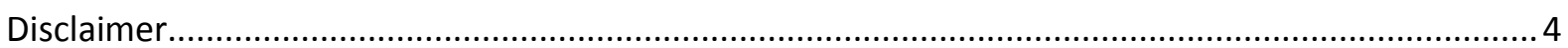

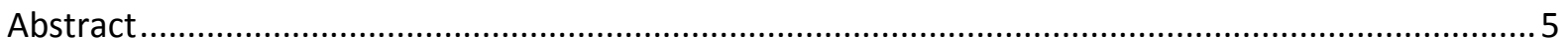

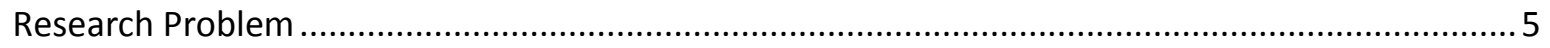

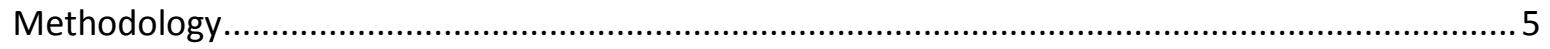

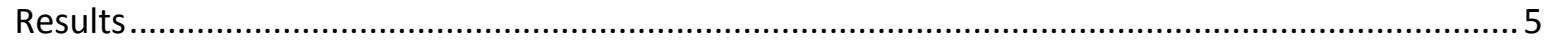

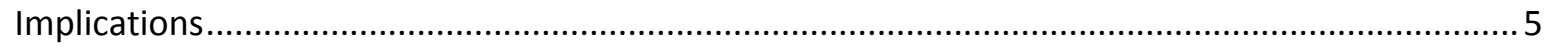

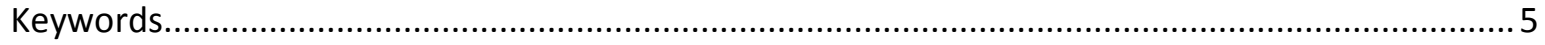

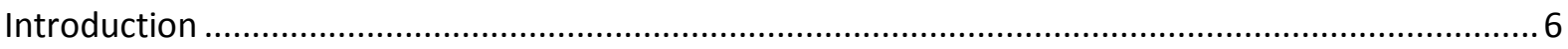

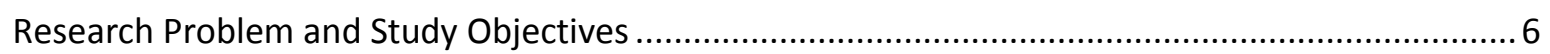

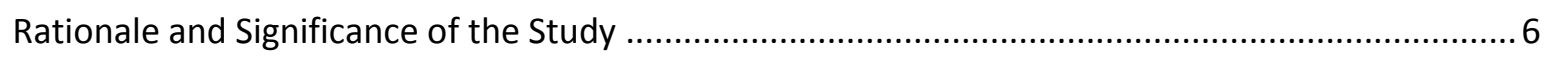

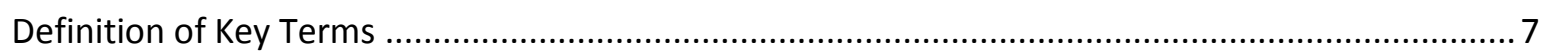

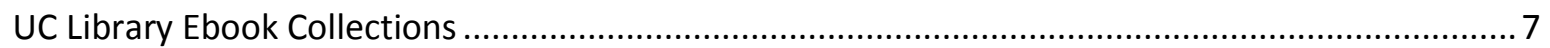

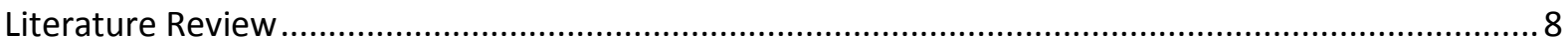

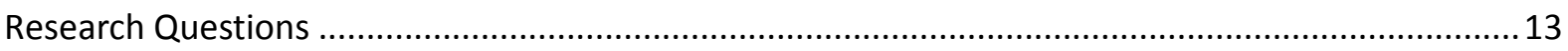

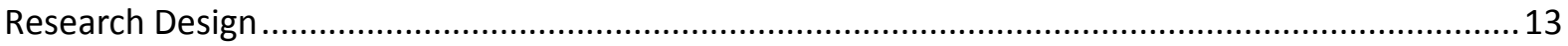

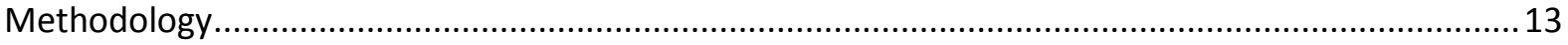

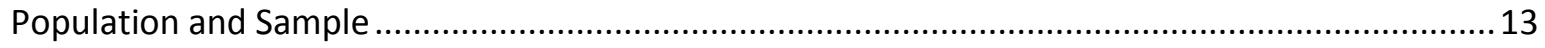

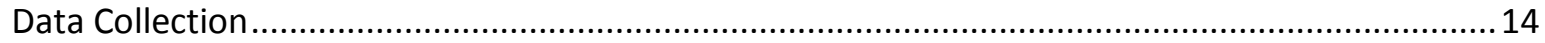

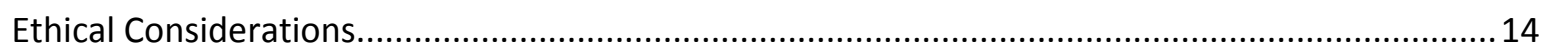

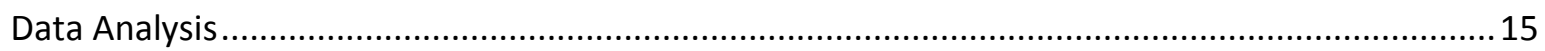

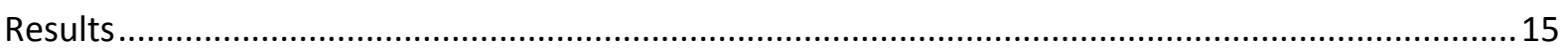

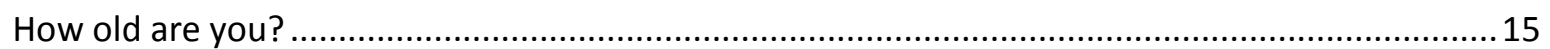

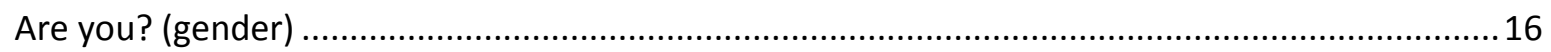

Are you a PhD student or an academic staff member? ................................................................ 16

With which College are you mainly affiliated in terms of your job or study? ................................17

Are you aware that the University of Canterbury Library provides access to ebooks?....................18

Have you used an ebook provided by the University of Canterbury Library? .................................. 18

Of the books you want to read what format are they usually available in? ................................... 19

Approximately what percentage of the University of Canterbury Library print book collection do you think is also available to you as an ebook in the university Library or somewhere else? .........20 
Have you used an ebook relevant to your primary subject area?

Please indicate in what format you would prefer that the University of Canterbury Library purchase the following types of resources:.

When doing your academic work, how important are the following features? (If you have never used an ebook, how important would these features be if considering using one?) .......................25

Select your response to the statements using the following scale:

Which of the following would make ebooks more suitable for use in your subject area for teaching and/or research? (select all that apply)...... 30

Select your response to the statements below using the following scale: ..................................... 32

Please add any other comments you may have about your use of ebooks in the box below......... 34

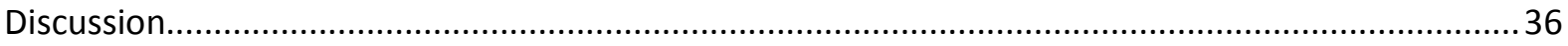

Are users aware of, and using, the ebook collections at the University of Canterbury and, if so,

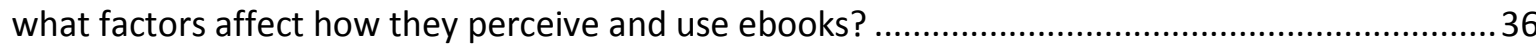

What types of written material, if any, do users prefer in either ebook or print format?.

What degree of practical overlap, that is the degree of overlap there is between print collection availability and ebook collection availability, do users' believe there is? ..........................................4 43

What factors, if any, affect users switching from print to ebook format? ....................................... 44

Does age affect users' perception of or use of ebooks and, if so, how does it affect their perception of or use of ebooks?

Does gender affect users' perception of or use of ebooks and, if so, how does it affect their perception of or use of ebooks?

Does academic status, that is if they are an academic or a PhD student, affect users' perception of or use of ebooks and, if so, how does it affect their perception of or use of ebooks?

Does academic discipline affect users' perception of or use of ebooks and, if so, how does it affect their perception of or use of ebooks?

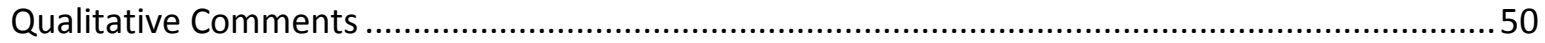

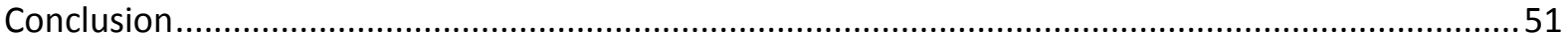

Recommendations

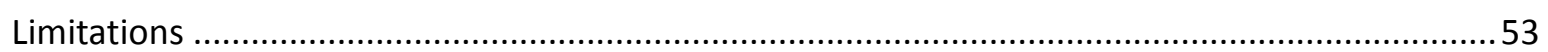

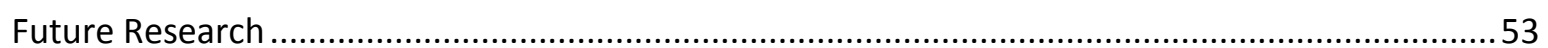

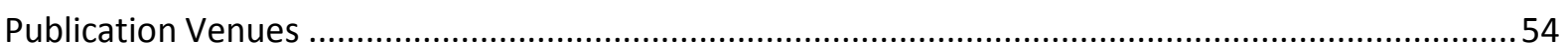

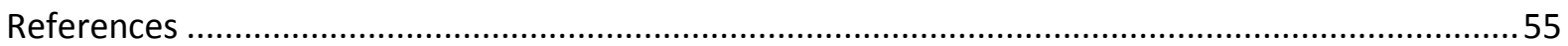

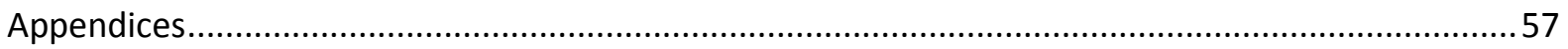

Appendix 1: Frequency of Use of Library Ebooks by Collage Full Results.......................................57

Appendix 2. Statistically Significant Format Preferences for Different Types of Book by Age Group

Appendix 3. Statistically Significant Format Preferences for Different Types of Book by Gender Group 
Appendix 4. Statistically Significant Format Preferences for Different Types of Book by Status Group

Appendix 5. Statistically Significant Format Preferences for Different Types of Book by College Group .59

Appendix 6. Importance of Particular Ebook Features .60

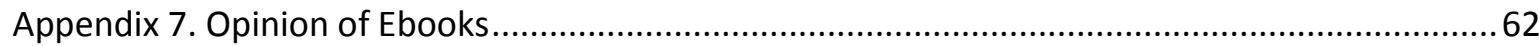

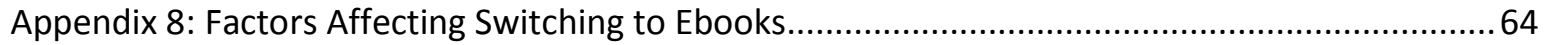

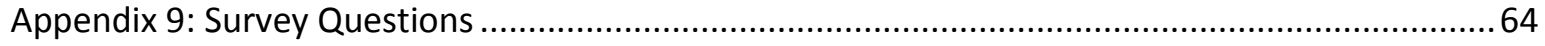

\section{Tables}

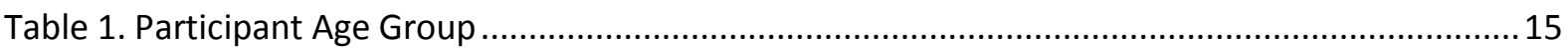

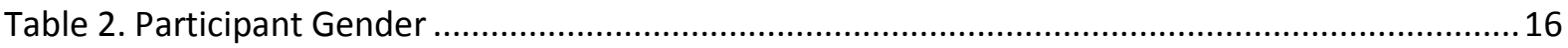

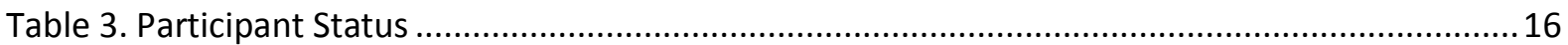

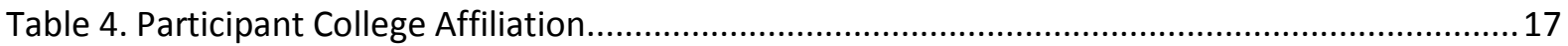

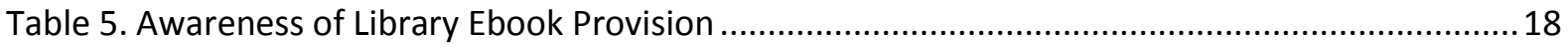

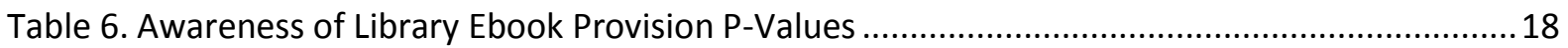

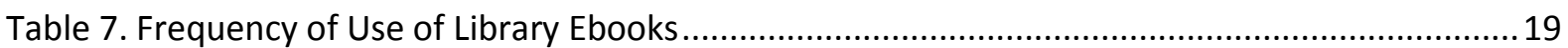

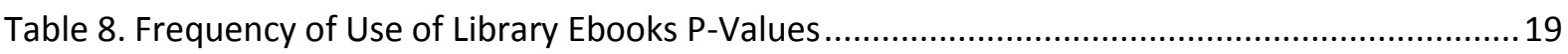

Table 9. Percentage by College for "At Least Once" and "Never" For use of Library Ebooks ..............19

Table 10. Perception of Availability of Books in Print and/or Ebook Format ......................................20

Table 11. Perception of Availability of Books in Print and/or Ebook Format P-Values ........................20

Table 12. Perception of Availability of Books in Print and/or Ebook Format Percentage by status ....20

Table 13. Perceived Practical Overlap of Print and Ebook Collections ..............................................21

Table 14. Perceived Practical Overlap of Print and Ebook Collections P-Values .................................... 21

Table 15. Perceived Practical Overlap of Print and Ebook Collections by Age, Gender and status .....21

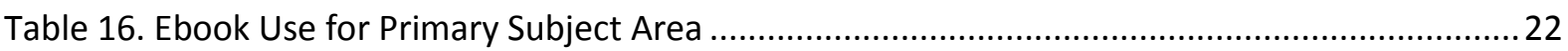

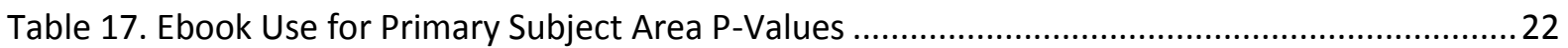

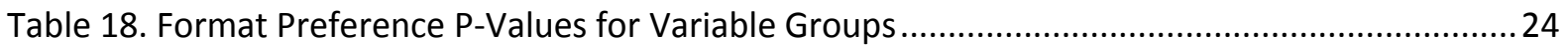

Table 19. Importance of Particular Ebook Features by Variable Group P-Values ...............................26

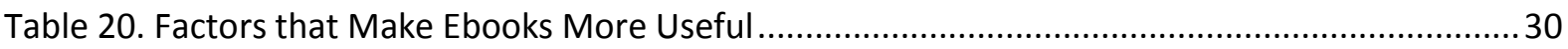

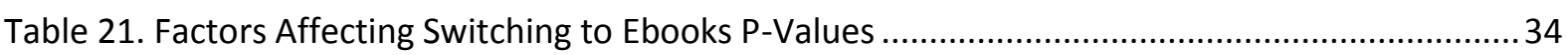

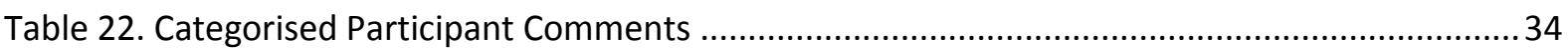

\section{Figures}

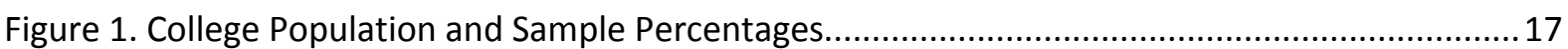

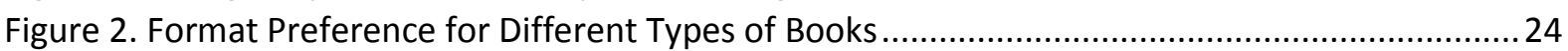

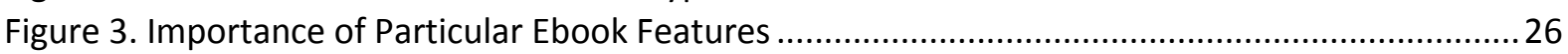

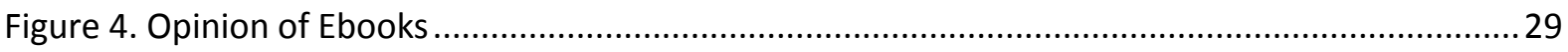

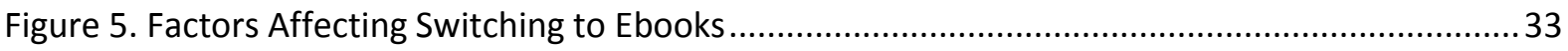




\title{
Disclaimer
}

\section{VICTORIA UNIVERSITY OF WELLINGTON \\ School of Information Management}

\author{
Master of Information Studies
}

IMPORTANT DISCLAIMER

with respect to a MIS Research Project (INFO 580)

\section{Attitudes towards and use of ebooks at the University of Canterbury.}

\section{(hereafter referred to as 'The MIS Research Project')}

\author{
being undertaken by
}

\section{Nick Scullin}

in partial fulfilment of the requirements of the degree of

Master of Information Studies,

School of Information Management, Victoria University of Wellington.

\section{Topic Commencement: Date November 2014}

1. Victoria University of Wellington and its Council, its members, staff, employees, students and agents undertake no duty of care in contract, tort, or otherwise, to users (whether direct or indirect) of the MIS Research Project and make no warranties or representations of any kind whatsoever in relation to any of its contents.

2. The MIS Research Project is only made available on the basis that all users of it, whether direct or indirect, must take appropriate legal or other expert advice in relation to their own circumstances and must rely solely on their own judgment and such legal or other expert advice.

3. Under no circumstances will Victoria University of Wellington and its Council, its members, staff, employees, students or agents be liable in any way whatsoever, whether in contract, tort (including negligence), for breach of any statutory or regulatory duty (to the fullest extent permissible by law), or otherwise, to any user (whether direct or indirect) of the MIS Research Project for any loss or damage whatsoever arising directly or indirectly as a result of the use in any way of the MIS Research Project.

4. Each exclusion in the clauses of this disclaimer and each protection given by it is to be construed as a separate exclusion applying and surviving even if for any reason any of the exclusions or protections are held inapplicable in any circumstance. 


\section{Abstract}

\section{Research Problem}

There is a contradiction surrounding ebooks in that they are becoming more and more common in academic libraries but evidence often suggests that users still prefer print books to ebooks. The purpose of the study is to examine how users at the University of Canterbury are using the Library's ebooks and what their attitudes towards ebooks are. The study also looks at what role age, gender, academic status and college affiliation play in shaping attitudes towards and use of ebooks.

\section{Methodology}

The study used an online survey to discover how ebooks were used and viewed by users at the University of Canterbury. The survey was largely quantitative but included several comments sections where users could give more qualitative answers. The population sampled was the academic staff and PhD students of the University of Canterbury.

\section{Results}

The results show that the participants are mostly aware of and using ebooks. Opinion is still divided on ebooks with some user still preferring print and many users preferring access to both print and ebooks. Age, gender, academic status and college affiliation all have some effect on attitudes towards and use of ebooks.

\section{Implications}

Academic libraries need to take note of the opinions their users have about ebooks so as to better meet their needs. Some of the problems around ebook use can be solved by increased user education but others are the result of restrictions placed on ebooks by publishers and vendors. Other problems are inherent to the ebook format and cannot be ignored. Academic libraries can best meet their users' needs by providing both print and ebook collections were possible.

\section{Keywords}

ebook, library, academic, university, attitude, use 


\section{Introduction}

\section{Research Problem and Study Objectives}

According to Posigha, "E-books have become tools of choice for researchers and students, particularly those belonging to the so-called digital generation who can access and browse contents at any moment from their laptops" (2012, p. 797). However, anecdotal evidence often suggests that many library users still prefer print books to ebooks (Corlett-Rivera \& Hackman, 2014; Smyth \& Carlin, 2012). This study builds on a study done at the University of Waikato, undertaken by Alistair Lamb in 2012, in order to discover if there are any similarities or differences at a different tertiary institution, namely the University of Canterbury (UC). The study also adds a broader understanding of ebook use at academic institutions in New Zealand while also adding to the international body of research on ebook use in academic contexts. Where similarities were found we can say that Lamb's results have, "validity and applicability across diverse contexts and situations" (Leedy \& Ormrod, 2013, p. 103). Research from a number of other studies is reviewed below which was used as a basis for expanding the work done by Lamb in 2012.

\section{Rationale and Significance of the Study}

According to Vasileiou", Rowley, and Hartley, "many surveys have been conducted that indicate that e-books are a central element of the information experience of the academic population, including staff and undergraduate and postgraduate students" (2012, p. 218). However, Vasileiou, Rowley, and Hartley (2009, as cited in Vasileiou, Rowley, \& Hartley, 2012) also noted that:

As e-books become more popular their adoption as a learning resource could have a major impact on academic libraries. This adoption poses a range of collection development issues such as acquisition policies and processes; pricing and licensing models and arrangements; cataloguing processes and promotional activities. (p. 218)

Corlett-Rivera and Hackman (2014) also note that most university libraries face space constraints and other factors that create pressure for them to purchase significant proportions of their collections in ebook format instead of in print format. Widdersheim states that, "E-lending is attractive for libraries because it enhances information access", and that, "by providing access to econtent and mobile technology to patrons, libraries exist beyond their physical walls, outside of scheduled hours, and offer patrons affordances they may not have with analog materials" (2014, p.95-96). Link makes a similar point to the above noting that, "libraries view e-books as a way to keep up with the demands of ... tech-savvy patrons while conserving or even reducing shelf usage and thereby repurposing valuable library floor space for group study or computer labs" (2012, p. 132). However, as Walters notes the advantages of ebooks are well publicised but, "in contrast, many of the challenges associated with academic e-books are not well known among librarians,

\footnotetext{
${ }^{1}$ Two articles apparently by the same author are cited in this draft research proposal but with a variation in the spelling of the family name of one of the authors: 'Vassiliou' for the 2008 article and 'Vasileiou' for the 2012 article.
} 
students, or university administrators" (2013, p. 187). Furthermore, Savova and Garsia state that, "despite the success of electronic resources in general, e-books, which have been on the market since the 1990's, have seen limited adoption among student populations" (2012, p. 206).

Clearly there is much research that still needs to be done to understand how users in academic contexts perceive and make use of ebooks. UC is no exception to the above points, and is looking to develop its ebook collection. Given the major impact ebooks are likely to have on the university's libraries it was important to find out how its users are currently using ebooks and what their attitudes towards ebooks are so as to better inform the library's decision making processes. With a better understanding of users attitudes towards ebooks, how they are using ebooks and what they perceive as the advantages or disadvantages of ebooks this study is both helpful to the UC Library as well as contributing more broadly to a better general understanding of how ebooks are perceived and used in academic libraries.

\section{Definition of Key Terms}

The definition used for ebooks in this study will be the same as that used by Lamb (2012) which was originally proposed by Vassiliou and Rowley (2008):

1. An e-book is a digital object with textual and/or other content, which arises as a result of integrating the familiar concept of a book with features that can be provided in an electronic environment.

2. E-books, typically have in-use features such [as] search and cross reference functions, hypertext links, bookmarks, annotations, highlights, multimedia objects and interactive tools. (p. 363)

Academic Staff are, "those [University of Canterbury staff] involved in teaching and/or research associated with their respective faculties, including affiliated research institutes" (Lamb, 2012, p. 1).

Postgraduate students are those students enrolled in any course of study at the University of Canterbury at a postgraduate level including Postgraduate Certificates, Postgraduate Diplomas, or Honours, Master's or Doctor of Philosophy degrees (University of Canterbury, n.d.).

\section{UC Library Ebook Collections}

The ebook collection at UC consists of single title ebooks and various packages of ebooks. In the last few years the UC Library has moved from a just in case collection model to a just in time model and now purchases ebooks on an individual bases. The last package of ebooks was purchased in 2013. Many ebook purchases are now based on the Patron-Driven Acquisition (PDA)/DemandDriven Acquisition (DDA) model. Under this model many ebook records in the library catalogue are not yet actually owned by the Library. If a user finds such an ebook, in most cases they will not notice any difference to owned ebooks but sometimes they might be prompted to click a link requesting the ebook be purchased. Library staff then make a decision on whether or not to purchase the ebook and with what restrictions. Some ebooks that are under a certain price are auto- 
purchased without the need for a librarian to review the purchase request after a certain number of short term loans.

Ebooks purchased form publisher's platforms are usually Digital Rights Management (DRM) free and therefore have no restrictions on use whereas ebooks purchased from aggregators such as EBL or EBSCOhost usually have DRM restrictions on use. The library will always purchase directly from publishers with no DRM unless this option is too expensive compared to purchasing from an aggregator with DRM, or the publishers do not provide the title themselves. Ebooks purchased from aggregators may be able to be used by 1 user at a time, 3 users at a time or multiple/unlimited users and the price varies accordingly. Purchases may also be under a non-linear model whereby the ebook can be used for a certain number of days each year by any number of users but once the days have been used up that year the library must purchase a second copy for users to continue to use the ebook. The Library tries to purchase unlimited user access ebooks where affordable but sometimes this is not possible and ebooks may be restricted to as little as 1 user at a time. The UC Library's ebook collections therefore vary in restrictions and platforms needed to access them. They range from permanently own ebooks that can be accessed by unlimited users through to ebooks that are not yet purchased and may only be available to a single user at a time. Some ebooks can be downloaded and kept forever while others must be downloaded and used via specific software such as Adobe Digital Editions and only used for a short period of time.

\section{Literature Review}

The literature review discusses some recent studies regarding ebooks and draws out concepts, methodological approaches or theories that were used to build on the work of Lamb in 2012. Lamb's (2012) study is discussed first as it forms the basis of this study and some aspects of this study replicate Lamb's approach in order for comparisons to be made that help to highlight differences or similarities that in turn help us to understand how ebooks are being used and perceived in universities in New Zealand or alternatively illustrate areas that need further research. Where this study confirms Lamb's (2012) results it means that his results are more likely to be valid and applicable across the New Zealand university sector (Leedy \& Ormrod, 2013). Some recent studies shed light on the issue but they also highlight that more research is still needed in the area of ebook use in academic libraries.

The Research objective of Lamb's study was, "to investigate academics' perception, uptake and use of ebooks at the University of Waikato" $(2012$, p. 8). Lamb investigated whether or not academics at the university were aware of the library's ebook collections, how they perceived ebooks, how they use ebooks within their teaching and research and what factors hinder or support ebook use. The research method used was an online quantitative questionnaire survey with a small qualitative comments section which was open to all academic staff involved in research and teaching at the university. Lamb found that academics at the university lacked, "awareness, competency and confidence towards the many aspects of the ebook environment" and that generally academics were not making use of ebooks to their full potential (2012, p. 54). However, Lamb's (2012) study did show that the majority of academics were aware of the university's ebook collections. Similarly, Borchert, Hunter, McDonald and Tittel (2009) found that between $70 \%$ and $80 \%$ of students and 
academic staff at two Queensland universities were aware of their universities respective ebook collections. Lamb (2012) also concluded that there was a need for improved technology, access and supply of ebooks and increased patron education to raise awareness of the ebooks offered and how to access and make use of them. Similarly, Corlett-Rivera and Hackman (2014) found that many users at the University of Maryland lacked awareness of the ebook collections and that further patron education was necessary. Slater also concluded that due to limitations in the mechanisms for finding and accessing ebooks provided by ebook vendors that, "increasing awareness and usage of these materials will rely largely on marketing and instructional campaigns" (2010, p. 327).

A limitation of Lamb's study is that it only targeted academics at the university rather than a broader approach of also including students in the study. This study addressed this limitation by also including PhD students in the research as well as academics. This approach allows for an investigation of what differences, exist between how academics and postgraduate students perceive and use ebooks. Where differences were identified they highlight issues that require further investigation while also providing the library with information that could be used to better meet the needs of these two user groups. Additionally the results may be of use to academics and academic departments looking to better meet the needs of their students and staff with regard to ebooks.

Corlett-Rivera and Hackman's study sought to, "gather data on use of and attitudes about ebooks among faculty, graduate students, and undergraduate students in the humanities and social sciences at the University of Maryland" (2014, p. 256). Their study attempted to discover users' preferences for accessing different kinds of written materials, such as scholarly monographs and reference works, what difficulties existed for finding and accessing ebooks and how suitable ebooks were for teaching and research at the university. There survey was limited to three colleges: the College of Arts and Humanities, the College of Behavioural and Social Sciences and the College of Education. The study is somewhat limited because of the approach of only targeting three colleges rather than the university's faculty and students as a whole. Furthermore, $73 \%$ of those who responded to the survey were from the College of Arts and Humanities further limiting the results for making generalisations (Corlett-Rivera \& Hackman, 2014).

This has a broader approach of targeting the academic staff and PhD students from across all the colleges at UC in order to build a more comprehensive picture of an academic population than Corlett-Rivera and Hackman's (2014) study and to allow detailed comparisons between academic colleges. Link's study at the College of New Jersey found that, "e-book coverage is not consistent across subjects", with, "the social sciences and technology ... more heavily represented ... while education and biological sciences are underrepresented" (2012, p. 134). Differences between colleges may also be the result of different attitudes to ebooks or different ways of using ebooks which this study examines.

Corlett-Rivera and Hackman's (2014) study found that users, especially those from the Humanities and Social Sciences have mixed opinions regarding ebooks. The study also highlighted the importance of e-reader ownership for increased ebook use (Corlett-Rivera and Hackman, 2014). E-reader ownership was also found to be an important factor in ebook use by Slater (2010) while, Savova and Garsia's (2012) examination of the e-reader loan programme at McGill University in Canada found that access to e-readers promotes the use of ebooks as they provide users with new 
ways to relate to, access and understand ebooks. As already noted above, awareness of ebook collections is a problem, with nine percent of respondents not being aware of the library's ebook collections or being unaware of how to use ebooks illustrating a need for more user education around ebooks (Corlett-Rivera \&Hackman, 2014). Finally, the study indicated a preference for ebooks for certain types of written material such as, general and specialized reference materials, citation manuals, and style guides while for some types of material such as, edited collections, scholarly monographs, and works of literature, participants did not show a clear preference for print or ebooks (Corlett-Rivera \& Hackman, 2014). Smyth and Carlin's study found that, "textbooks were the most popular type of ebook (56\%), followed by fiction (19\%), research monographs (18\%) and encyclopedias and dictionaries (7\%)" (2012, p. 186). Clearly users prefer certain types of written material over others for use in an ebook format. This study examines what type of written material is preferred in ebook format at UC.

Posigha's (2012) study investigated the use of and future of ebooks in academic institutions in Nigeria by conducting a study at the Niger Delta University. Posigha (2012) examined if there were any differences in how academic staff from two different faculties used ebooks and also if there were any differences in how male and female academics used ebooks. Posigha (2012) tested three hypotheses with his study with regard to the use of ebooks, postulating that there is no significant relationship between:

1. basic medical science lecturers and education lecturers

2. female and male lecturers

3. the constraints encountered by female and male lecturers ( $p .798$ )

Posigha's data were analysed with a chi-square test to test the three hypotheses. Posigha (2012) found that all the participants make use of ebooks in their research and teaching. In comparison, Lamb (2012) found that $94 \%$ of the academics had used an ebook relevant to their primary subject area but that only $63 \%$ are using ebooks in the course materials or course readings. Corlett-Rivera and Hackman's (2014) study found that $31 \%$ of respondents never used ebooks for research. It is hard to make direct comparisons between these studies as they asked different questions of their participants however it would appear that their results are somewhat at odds in terms of to what degree academic library users are using ebooks for research or teaching. There is evidently still much work to be done to discover how often academics and students are making use of ebook collections and this study adds to a better understanding in this respect.

Posigha's (2012) chi-square testing of his results rejected the hypotheses that there was no significant relationship between faculty and use of ebooks and between gender and use of ebooks. He found that there was greater use of ebooks made by lecturers from the Faculty of Basic Medical Sciences conforming to previous studies that show ebooks are more heavily used in the sciences than in other academic disciplines (Posigha, 2012). The results also confirmed a previous study's results showing that men make more frequent use of ebooks than women (Monopoli et al., 2002, as cited in Posigha, 2012). Interestingly there was no significant relationship found between gender and the constraints encountered by the lecturers when using ebooks which brings up the question of why this is different to the result for use of ebooks between the genders. The proposed study will thus seek to investigate these issues at UC in order to test Posigha's findings at a different institution 
and will further seek to clarify what factors may influence differences in perception of and use of ebooks according to gender or faculty membership, where any such differences are identified.

Anderson and Pham (2013) postulated that there is a commonly held belief that most scholarly material available in print format is also available in ebook format, leading to the idea that ebooks can largely replace print collections. Anderson and Pham (2013) use the term practical overlap to designate the degree to which print and ebook collections overlap with each other in terms of the availability of the same titles. Anderson and Pham's (2013) research objective was to test to what extent the print collection at RMIT University was also available in ebook format. The methodology used by Anderson and Pham (2013) involved them selecting a random sample of unique monograph titles from the entire print collection of the library. A manual search for each title from the sample was then conducted in three different sources: GOBI, the university's main supplier of collection materials, Amazon and a general Google search. Anderson and Pham (2013) found that a maximum of $33 \%$ of print titles held in the library were available as ebooks and that on a practical basis only about $26 \%$ could be readily obtained as ebooks by the library. These results were similar to previous studies that found comparable levels of print and ebook practical overlap of between $17 \%$ and 31\% (Link, 2012; Pomerantz, 2010; Price \& McDonald, 2008, as cited in Anderson \& Pham, 2013).

While it is beyond the scope of this study to examine the actual practical overlap at UC, what it does is look at users' perception of the practical overlap that exists, with questions that ask participants to state what they believe the practical overlap is. This information is useful because the perceived level of practical overlap may contribute to use of and attitudes towards. An interesting future study would be to examine the actual practical overlap at the university and then to compare this result with the perceived practical overlap from this study.

Sanford (2013) investigated users switching from non-IT artifacts to IT artifacts to determine different types of switching predictors by examining data from a longitudinal study of users switching from print books to ebooks. Specifically, Sanford (2013) sought to examine what factors predict user tendency to switch from a print book to an ebook and how these factors enable or constrain artifact switching. Sanford (2013) used migration theory (Lee, 1966, as cited in Sanford, 2013), from the human geography literature, and applied it to artifact switching in order to better understand the process with regard to users switching from print books to ebooks. Migration Theory was developed to explain why people migrate from one place to another (Lee, 1966, as cited in Sanford, 2013). Migration Theory understands human migration in terms of certain factors that affect people: push factors, pull factors, intervening obstacles and individual differences. Sanford (2013) applied these factors to explain artifact switching with regard to users switching from print books to ebooks.

Sanford's push factor consists of users' level of satisfaction with print books; "satisfied users tend to continue their use of an incumbent artifact, while dissatisfied users are more likely to discontinue its use and possibly switch to a substitute" (2013, p. 24). Sanford examined two pull factors, the relative advantage of switching to a new IT artifact and the subjective norm, also called social influence, which refers to the influence of one's peers on one's behaviour. Sanford's intervening obstacle is switching cost which is the cost in terms of money and time and effort involved in switching to a new IT artifact. Switching cost also negatively impacts on push and pull 
factors meaning that even if strong push and pull factors are present high switching cost may still prevent users from switching to a new IT artifact (Lee, 1966, as cited in Sanford, 2013). The last factor that Sanford (2013) investigated was individual differences in the form of personal innovativeness, which refers to an individual's propensity to experiment with new technologies. An individual's personal innovativeness can either increase or decrease their chances of IT artifact switching regardless of the other factors already discussed (Sanford, 2013).

Sanford's (2013) tested a number of hypotheses about artifact switching with a longitudinal study of 285 Hanyang University students switching from print books to ebooks. Sanford found that, "the push factor, or the level of satisfaction with the incumbent artifact and the intervening obstacle, switching cost, influences artifact switching the most", while the pull factors and personal innovativeness also affect artifact switching to a lesser extent (2013, p. 36). Sanford also found that switching cost negatively moderates push and pull factors associated with switching from a print book to an ebook. The current study includes questions to examine whether or not Sanford's factors, derived from Migration Theory, affect users at UC with regard to switching from print books to ebooks.

Various studies (For example: Corlett-Rivera \& Hackman, 2014; Lamb, 2012; Posigha, 2012) investigated attitudes towards and use of ebooks in a university context and provide a useful basis for conducting a similar study at UC. Results from the study are compared with these studies' results in order to ascertain any similarities or differences that exist in order to add to a broader understanding of ebook use at academic institutions in New Zealand while also adding to the international body of research on ebook use in academic contexts. Where results from these studies are confirmed at a different institution it adds validity and applicability to the results across diverse contexts thus strengthening our confidence in the results (Leedy \& Ormrod, 2013). In addition Corlett-Rivera and Hackman's (2014) study and earlier studies such as Link's (2012) study provide a useful framework for assessing what types of written material users at UC prefer in ebook format or print format and the results in the proposed study can be compared with their results.

Posigha (2012) Corlett-Rivera and Hackman (2014) investigated if there was a difference in how academics from different faculties used ebooks which this study also does. Posigha (2012) also investigated if there was a difference between female and male users' use of ebooks, which provides a useful basis for investigating these factors at UC. Anderson and Pham (2013) investigated practical overlap between print and ebook availability which informs the current study's examination of users' perception of the degree of practical overlap that exists in the UC Library's ebook and print collections. Sanford (2013) used migration theory to analyse factors that affect users switching from print books to ebooks which provides a useful framework for assessing what factors affect users with regard to switching from print books to ebooks. Additionally the effect of participant's age on ebook use is also investigated as this variable was not included any of the previous studies discussed but may well have an effect on ebook use. 


\section{Research Questions}

The following research questions have been developed from the literature review and will be used as the basis of the study:

* Are users aware of and using the ebook collections at the University of Canterbury and, if so, what factors affect how they perceive and use ebooks?

$>$ Does age affect users' perception of or use of ebooks and, if so, how does it affect their perception of or use of ebooks?

$>$ Does academic discipline affect users' perception of or use of ebooks and, if so, how does it affect their perception of or use of ebooks?

$>$ Does gender affect users' perception of or use of ebooks and, if so, how does it affect their perception of or use of ebooks?

$>$ Does academic status, that is if they are an academic or a PhD student, affect users' perception of or use of ebooks and, if so, how does it affect their perception of or use of ebooks?

$>$ What types of written material, if any, do users prefer in either ebook or print format?

$>$ What degree of practical overlap, that is the degree of overlap there is between print collection availability and ebook collection availability, do users' believe there is?

What factors, if any, affect users switching from print to ebook format?

\section{Research Design}

Following on from Lamb's study, "a cross-sectional research design utilising a quantitative approach will allow for a study that will uncover particular trends and characteristics, and display them after analysis in a numerical and statistical fashion" $(2012$, p. 9). The research was conducted using a quantitative survey research approach which enabled the researcher to learn about a large population, the UC Library's academic staff and PhD students, by surveying a sample of that population and drawing conclusions based on the responses of the sample (Leedy \& Ormrod, 2013).

\section{Methodology}

\section{Population and Sample}

The population for the study was exclusively made up of the academic staff and PhD students of UC, unlike Lamb's (2012) study that only looked at academic staff. The total number currently enrolled PhD students and academic staff, as of April 2015, represents the total population from which an appropriate sample size was calculated. These numbers were obtained from university administration staff (A. Feng, personal communication, March 31, 2015). The total 
number of PhD students enrolled at the university was 857 , while the total number of academic staff at the university was 1183 , giving a total population size of 2,040 .

The study made use of the free sample size calculator provided by Qualtrics (http://www.qualtrics.com/blog/calculating-sample-size/). With a confidence level of $95 \%$ and a margin of error of $5 \%$ the calculator gave an ideal sample size of 324 from the total population of 2,040 . For the total academic staff population of 1,183 with the same confidence level and margin of error the sample size was 290. Similarly, for the total population of PhD students the sample size obtained was 266 . The total number of participants who responded to the survey was 613 , however only 276 were academic staff which was a little lower than the target sample of 290.287 participants were PhD students surpassing the target sample of 266. A further 47 participants answered Other to the question about academic status and three participants did not answer the question. The sample is thus relatively representative of the whole population.

\section{Data Collection}

Similar to previous studies identified in the literature review (Corlett-Rivera \& Hackman, 2014; Lamb, 2012) this study collected data via an online survey, created and provided using the software Qaultrics (http://www.qualtrics.com/). The survey had mainly quantitative questions designed to answer the research questions set out above, with a small qualitative component that added to the understanding gained from the quantitative questions by allowing participants to further explain or add to their previous answers. The Survey was left up for 10 days from 10 April 2015 until 20 April 2015 and a reminder was sent out to participants who had not yet answered the survey on 15 April 2015 in order to maximise participation. Additionally, participants had the chance to enter a random prize draw for a $\$ 25.00$ movie shopping voucher to encourage participation. Some questions were identical or very close to Lamb's (2014) questions in order to make direct comparisons possible, while other questions are broadly similar to those of previous studies but tailored to answer the research questions of this study.

The survey was conducted on the researcher's behalf by the UC Surveys Coordinator. This ensured the anonymity of the study as only the Surveys coordinator had the full list of names of those that the survey was sent to. After the survey had been taken down an anonymous dataset of responses was provided to the researcher by the Surveys Coordinator that did not include participants' names or any other identifier. In addition, the Surveys Coordinator also randomly selected the winner of the prize draw and supplied the email address to the researcher who then contacted the winner and provided them with the prize. The data from the survey was provided in an Excel file along with a copy of the survey with the coding of each question included.

\section{Ethical Considerations}

As the study has human participants approval from the Victoria University of Wellington Human Ethics Committee (HEC) was needed before the study could be conducted (Victoria University of Wellington, [VUW], n.d.). Approval was obtained in writing from the School of Information Management Human Ethics Committee on the 31 March 2015. The study was 
completely anonymous but there was still a small risk of participants being identified by their answers to open-ended questions and therefore, comments displayed from this section were summarised to avoid any chance of identification (Lamb, 2012).

\section{Data Analysis}

The survey data was provided to the researcher by the Surveys Coordinator in a Microsoft Excel spreadsheet with number-coded data representing the participants' answers to the questions. The data is all ordinal or nominal data. Using the choose function (=CHOOSE) in Excel the coded data was turned into the actual answers from the survey so as to be able to more easily used in pivot tables. Pivot tables were then used to create contingency tables showing the frequency and percentage for participant answers to particular questions. The frequencies in the contingency tables were then imputed into an online Chi-square test calculator to determine whether or not there were statistically significant variations in participants' answers based on four variables: age, gender, status (PhD or academic staff) and college affiliation. Similarly to Lamb (2012) the data has been analysed on the spreadsheet in order to formulate trends and characteristics of the users' attitudes towards and use of ebooks at UC. Tables and graphs were relied upon to reveal trends in the data (Vaughan, 2001). Chi-square tests were performed when the data for different groups needed to be compared (Posigha, 2012; Vaughan, 2001). As mentioned earlier, and following Lamb's (2012) study, the qualitative comments were grouped into contextually similar groups and analysed in order to ascertain any relationship to the statistical results that could help in understanding the trends and characteristics of the quantitative data.

\section{Results}

The results are given for each question below. Where necessary, tables or graphs are used to illustrate the data. Some tables are not shown in the results section but are instead included in appendices. The data is presented by question and with associated Chi-square test results of the different groups being compared. Significant results and trends are highlighted when they occur.

\section{How old are you?}

As Table 1 shows, 612 of the 613 participants answered this question with only 5 participants indicating that they would rather not say their age group. The Age groups of the participants were fairly evenly distributed with the largest number of participants being in the $30-$ 39 group with $28.76 \%$ while the $40-49$ group was the smallest at $18.79 \%$ if we discount the $0.82 \%$ who answered I'd rather not say to this question.

Table 1. Participant Age Group

\begin{tabular}{|c|c|c|}
\hline Age & Frequency & Percentage \\
\hline $20-29$ & 159 & $25.98 \%$ \\
\hline $30-39$ & 176 & $28.76 \%$ \\
\hline $40-49$ & 115 & $18.79 \%$ \\
\hline
\end{tabular}




\begin{tabular}{|c|c|c|}
\hline $50+$ & 157 & $25.65 \%$ \\
\hline I'd rather not say & 5 & $0.82 \%$ \\
\hline Grand Total & $\mathbf{6 1 2}$ & $\mathbf{1 0 0 . 0 0 \%}$ \\
\hline
\end{tabular}

\section{Are you? (gender)}

As illustrated in Table 2, the gender of the participants was relatively evenly divided with $46.24 \%$ female and $52.78 \%$ male with only about $1 \%$ saying that they would rather not say and no participants choosing the Other (please specify) option. As with the age question only 1 participant did not answer this question.

Table 2. Participant Gender

\begin{tabular}{|c|c|c|}
\hline Gender & Frequency & Percentage \\
\hline Female & 283 & $46.24 \%$ \\
\hline Male & 323 & $52.78 \%$ \\
\hline I'd rather not say & 6 & $0.98 \%$ \\
\hline Other (please specify) & 0 & $0.00 \%$ \\
\hline Grand Total & $\mathbf{6 1 2}$ & $\mathbf{1 0 0 . 0 0 \%}$ \\
\hline
\end{tabular}

\section{Are you a PhD student or an academic staff member?}

As shown in Table 3, 610 participants answered this question and 3 participants did not. There was a close to even split between academics and PhD students with $45.25 \%$ and $47.05 \%$ respectively. However, 47 participants representing $7.70 \%$ of the answers chose the Other option. The email addresses used by the Surveys Coordinator as supplied by university administration staff was supposed to include only PhD students and academic staff members but apparently there system for identifying participants was not completely accurate or perhaps the list was not completely accurate and some people have since ceased to be enrolled as PhD students or ceased employment as academic staff. Some people may also have misunderstood the question.

Table 3. Participant Status

\begin{tabular}{|c|c|c|}
\hline Status & Frequency & Percentage \\
\hline Academic & 276 & $45.25 \%$ \\
\hline PhD & 287 & $47.05 \%$ \\
\hline Other & 47 & $7.70 \%$ \\
\hline Grand Total & $\mathbf{6 1 0}$ & $\mathbf{1 0 0 . 0 0 \%}$ \\
\hline
\end{tabular}




\section{With which College are you mainly affiliated in terms of your job or study?}

In Table 4 we can see that 611 participants answered the question of the 613 total participants. Less than $1 \%$ answered Other meaning that almost all participants gave the college they are mainly affiliated with. Engineering and Science were the two largest groups represented with $29.13 \%$ and $27.17 \%$ respectively equating to over half the participants together.

Table 4. Participant College Affiliation

\begin{tabular}{|c|c|c|}
\hline College & Frequency & Percentage \\
\hline Arts & 104 & $17.02 \%$ \\
\hline Business \& Law & 71 & $11.62 \%$ \\
\hline Education & 86 & $14.08 \%$ \\
\hline Engineering & 166 & $27.17 \%$ \\
\hline Science & 178 & $29.13 \%$ \\
\hline Other & 6 & $0.98 \%$ \\
\hline Grand Total & $\mathbf{6 1 1}$ & $\mathbf{1 0 0 . 0 0 \%}$ \\
\hline
\end{tabular}

Figure 1, compares the overall population percentage for each college with the sample percentages from the survey. The population percentages where obtained from UC administration staff prior to the survey commencement (A. Feng, personal communication, March 31, 2015). It should be noted that the population statistics are slightly inaccurate as $4.91 \%$ of the numbers given for the population total where persons who were listed for more than one college. We can see that Colleges of Business and Law and Education were underrepresented in the survey results while the Colleges of Engineering and Arts were over represented. The College of Science sample percentage was about equal to the population percentage.

Figure 1. College Population and Sample Percentages

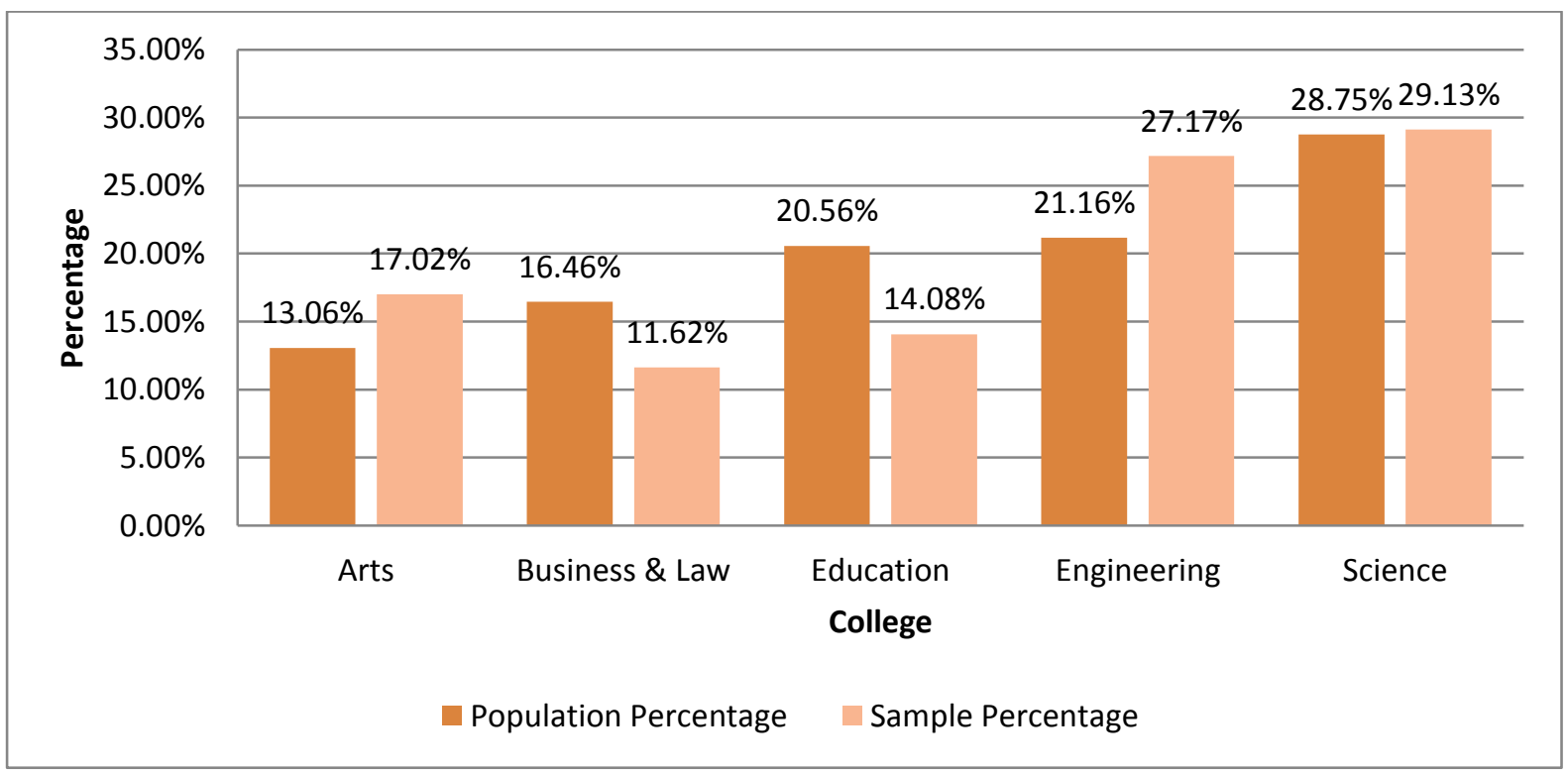




\section{Are you aware that the University of Canterbury Library provides access to ebooks?}

The results for the question about awareness of Library provision of access to ebooks, as laid out in table 5, showed that an overwhelming majority, $91.82 \%$, of the 611 participants who answered the question were aware that the Library provided access to ebooks. Furthermore, these results held true across all the different groups being compared. Table 6 , illustrates that the Chisquare test results P-Values for all groups, showed no statistically significant relationship between groups and their answers, that is, regardless of age, gender, academic status or college the results were not significantly different. The small percentage of users who answered no to this question automatically skipped the next three questions in the survey that related specifically to the UC Library's ebook collections rather than to ebook use in general.

Table 5. Awareness of Library Ebook Provision

\begin{tabular}{|c|c|c|}
\hline Answer & Frequency & Percentage \\
\hline No & 50 & $8.18 \%$ \\
\hline Yes & 561 & $91.82 \%$ \\
\hline Grand Total & $\mathbf{6 1 1}$ & $\mathbf{1 0 0 . 0 0 \%}$ \\
\hline
\end{tabular}

Table 6. Awareness of Library Ebook Provision P-Values

\begin{tabular}{|c|c|c|}
\hline Variable & P-Value & $\mathbf{P}<\mathbf{0 . 0 5}$ \\
\hline Age & 0.181014 & No \\
\hline Gender & 0.315997 & No \\
\hline Status & 0.7405 & No \\
\hline College & 0.068755 & No \\
\hline
\end{tabular}

\section{Have you used an ebook provided by the University of Canterbury Library?}

Table 7 gives the results for the question about how often participants have used ebooks provided by the UC Library. 562 participants answered this question meaning that only 1 participant did not answer the question out of the 563 people who were not automatically skipped past this question. Half of the participants, $50.18 \%$, who are aware that the Library provides access to ebooks, had used an ebook a couple of times while $27.58 \%$ of the participants had used an ebook often. A further $8.19 \%$ had used an ebook once while only $14.06 \%$ of the participants had never used an ebook provided by the Library. The vast majority of participants who are aware that the library provides access to ebooks have thus used a library ebook at least once, with $77.76 \%$ of participants having used an ebook more than once. If we add the participants who were not aware that the Library provides access to ebooks to those that answered never we get 129 participants which means that $21.04 \%$ of the total sample of 613 participants have never used an ebook from the Library while $78.96 \%$ have. 
The P-Values for the various groups compared, as laid out in Table 8, showed no statistically significant relationships except for by College which had a P-Value less than 0.05 . Table 9 makes it clear where the statistically significant relationships between participants' answers and their college lie. For the whole sample, $85.94 \%$ of those who answered had used an ebook at least once (answers Often, A couple of times and Once combined) while $14.06 \%$ had never used an ebook from the Library. The Colleges of Education, Engineering and Science participants closely conformed to this pattern. The Colleges of Arts and Business and Law, however, did not. Arts participants had a much higher at least once percentage at $94.06 \%$ while Business and Law had a much lower percentage at 77.94\% (for a full breakdown of participant answers by college and not combined see Appendix 1).

Table 7. Frequency of Use of Library Ebooks

\begin{tabular}{|c|c|c|}
\hline Answer & Frequency & Percentage \\
\hline Often & 155 & $27.58 \%$ \\
\hline A couple of times & 282 & $50.18 \%$ \\
\hline Once & 46 & $8.19 \%$ \\
\hline Never & 79 & $14.06 \%$ \\
\hline Grand Total & $\mathbf{5 6 2}$ & $\mathbf{1 0 0 . 0 0 \%}$ \\
\hline
\end{tabular}

Table 8. Frequency of Use of Library Ebooks P-Values

\begin{tabular}{|c|c|c|}
\hline Variable & P-Value & $\mathbf{P}<\mathbf{0 . 0 5}$ \\
\hline Age & 0.246133 & No \\
\hline Gender & 0.250551 & No \\
\hline Status & 0.197678 & No \\
\hline College & 0.00388 & Yes \\
\hline
\end{tabular}

Table 9. Percentage by College for "At Least Once" and "Never" For use of Library Ebooks

\begin{tabular}{|c|c|c|c|}
\hline College & \% At least once & \% Never & Grand Total \\
\hline Whole sample & $85.94 \%$ & $14.06 \%$ & $100.00 \%$ \\
\hline Arts & $94.06 \%$ & $5.94 \%$ & $100.00 \%$ \\
\hline Business \& Law & $\mathbf{7 7 . 9 4 \%}$ & $\mathbf{2 2 . 0 6 \%}$ & $100.00 \%$ \\
\hline Education & $84.62 \%$ & $15.38 \%$ & $100.00 \%$ \\
\hline Engineering & $85.53 \%$ & $14.47 \%$ & $100.00 \%$ \\
\hline Science & $85.99 \%$ & $14.01 \%$ & $100.00 \%$ \\
\hline
\end{tabular}

\section{Of the books you want to read what format are they usually available in?}

Table 10 provides the answers for what format participants believe the books they want to read are usually available to them in. 3 potential participants did not answer this question while 560 did answer. Over half the participants, 57.14\%, believed that usually the books they want to read are available in both print and ebook format. Close to a third believed they had access to print only with $28.93 \%$ while only $13.93 \%$ chose ebook only. The Chi-square test P-values revealed a statistically 
significant relationship only for the status group answers as detailed in Table 11. Table 12 highlights the percentage of each answer for the whole sample and the two status groups of PhD students and Academic staff. We can see that the Academic staff showed higher percentages for Print only and Print and ebook but a lower score for ebook only than the whole sample. The PhD students showed the opposite pattern, with lower percentages for the first two options and a higher percentage for ebook only. Academics are thus somewhat skewed towards print availability while PhD students are skewed towards ebook availability.

Table 10. Perception of Availability of Books in Print and/or Ebook Format

\begin{tabular}{|c|c|c|}
\hline Answer & Frequency & Percentage \\
\hline Print only & 162 & $28.93 \%$ \\
\hline Print and ebook & 320 & $57.14 \%$ \\
\hline Ebook only & 78 & $13.93 \%$ \\
\hline Grand Total & 560 & $100.00 \%$ \\
\hline
\end{tabular}

Table 11. Perception of Availability of Books in Print and/or Ebook Format P-Values

\begin{tabular}{|c|c|c|}
\hline Variable & P-Value & $\mathbf{P}<\mathbf{0 . 0 5}$ \\
\hline Age & 0.503718 & No \\
\hline Gender & 0.823782 & No \\
\hline Status & 0.009976 & Yes \\
\hline College & 0.585519 & No \\
\hline
\end{tabular}

Table 12. Perception of Availability of Books in Print and/or Ebook Format Percentage by status

\begin{tabular}{|c|c|c|c|c|}
\hline Status & Print only & Print and ebook & Ebook only & Grand Total \\
\hline Whole Sample & $28.93 \%$ & $57.14 \%$ & $13.93 \%$ & $100.00 \%$ \\
\hline Academic & $30.59 \%$ & $61.18 \%$ & $8.24 \%$ & $100.00 \%$ \\
\hline PhD & $26.82 \%$ & $54.02 \%$ & $19.16 \%$ & $100.00 \%$ \\
\hline
\end{tabular}

\section{Approximately what percentage of the University of Canterbury Library print book collection do you think is also available to you as an ebook in the university Library or somewhere else?}

As illustrated in table 12, 554 participants out of the possible 563 answered this question. The $20 \%$ - 39\% option was chosen by the largest number of participants with $42.60 \% .0 \%-19 \%$ was the next most frequent choice with $32.31 \%$ followed by $40 \%-59 \%$ with $19.49 \%$. The remaining two choices comprising the $60 \%-79 \%$ and $80 \%-100 \%$ answers had a combined total of only $5.59 \%$ clearly showing that results are skewed to the to $0 \%-60 \%$ range. Very few participants believe that the practical overlap is more than $59 \%$ and well over half (74.91\%) believe that it is under $40 \%$.

The P-values presented in table 4 show that there is a statistically significant relationship with the participants answers and three of the four variable groups compared in the study. Age, 
Gender and Status all had P-values of less than 0.05. Table 15 illustrates the range of different answers for the three groups with significant results. We can see that there is significant variation of answers amongst groups compared to the overall sample answers. For the different age groups the $20-29$ age was most similar to the whole sample. The $30-39$ groups' answers were heavily concentrated in the $20 \%$ - 39\% answer with $54.43 \%$. The $40-49$ year old group showed a different pattern again with their answers for $0 \%-19 \%$ and $20 \%$ - 39\% practical overlap exactly the same with $35.51 \%$. The trend for the $50+$ group was for lower percentage practical overlap answers with $43.66 \%$ for the $0 \%-19 \%$ and a further $38.03 \%$ for the $20 \%$ - 39\% and only $14.79 \%$ for $39 \%-60 \%$. The oldest age group clearly are more inclined to believe that the practical overlap is lower than some other age groups.

Gender also showed variation with quite different results for males and females. Half of all females $(49.23 \%)$ chose $20 \%$ - 39\%. The majority of the other female answers where split relatively evenly on either side with $25.38 \%$ for $0 \%-19 \%$ and $21.54 \%$ for $40 \%-59 \%$. The trend for males was similar to the $40-49$ age group with the majority of their scores split evenly between the $0 \%-19 \%$ and $20 \%$ - 39\% practical overlap with $37.85 \%$ and $37.15 \%$ respectively. Academic staff showed a trend towards slower practical overlap with $37.05 \%, 45.82 \%, 13.55 \%$ respectively for the $0 \%-19 \%$, $20 \%-39 \%$ and $40 \%-59 \%$ answers. PhD students showed a trend towards slightly higher practical overlap answers with $29.07 \%, 39.92 \%$, and $23.64 \%$ respectively for the same three answer choices. The groups with highest percentage of answers for practical overlap $60 \%-100 \%$ were males, PhD students and the status other group with around $7 \%$ while the three groups with the lowest practical overlap answer for $60 \%-100 \%$ were the $50+$ age group, females and academic staff with around $3.5 \%$.

Table 13. Perceived Practical Overlap of Print and Ebook Collections

\begin{tabular}{|c|c|c|}
\hline Answer & Frequency & Percentage \\
\hline $0 \%-19 \%$ & 179 & $32.31 \%$ \\
\hline $20 \%-39 \%$ & 236 & $42.60 \%$ \\
\hline $40 \%-59 \%$ & 108 & $19.49 \%$ \\
\hline $60 \%-79 \%$ & 25 & $4.51 \%$ \\
\hline $80 \%-100 \%$ & 6 & $1.08 \%$ \\
\hline Grand Total & 554 & $100.00 \%$ \\
\hline
\end{tabular}

Table 14. Perceived Practical Overlap of Print and Ebook Collections P-Values

\begin{tabular}{|c|c|c|}
\hline Variable & P-Value & $\mathbf{P}<\mathbf{0 . 0 5}$ \\
\hline Age & 0.001755 & Yes \\
\hline Gender & 0.005779 & Yes \\
\hline Status & 0.021544 & Yes \\
\hline College & 0.303202 & No \\
\hline
\end{tabular}

Table 15. Perceived Practical Overlap of Print and Ebook Collections by Age, Gender and status

\begin{tabular}{|c|c|c|c|c|c|c|}
\hline Group & $\begin{array}{c}0 \%- \\
19 \%\end{array}$ & $\begin{array}{c}20 \%- \\
39 \%\end{array}$ & $\begin{array}{c}40 \%- \\
59 \%\end{array}$ & $\begin{array}{c}60 \%- \\
79 \%\end{array}$ & $\begin{array}{c}\mathbf{8 0} \%- \\
100 \%\end{array}$ & $\begin{array}{c}\text { Grand } \\
\text { Total }\end{array}$ \\
\hline Whole Sample & $32.31 \%$ & $42.60 \%$ & $19.49 \%$ & $4.51 \%$ & $1.08 \%$ & $100.00 \%$ \\
\hline
\end{tabular}




\begin{tabular}{|c|c|c|c|c|c|c|c|}
\hline \multirow{4}{*}{ Age } & $20-29$ & $31.69 \%$ & $39.44 \%$ & $23.24 \%$ & $4.23 \%$ & $1.41 \%$ & $100.00 \%$ \\
\hline & $30-39$ & $20.25 \%$ & $54.43 \%$ & $18.99 \%$ & $5.70 \%$ & $0.63 \%$ & $100.00 \%$ \\
\hline & $40-49$ & $35.51 \%$ & $35.51 \%$ & $22.43 \%$ & $6.54 \%$ & $0.00 \%$ & $100.00 \%$ \\
\hline & $50+$ & $43.66 \%$ & $38.03 \%$ & $14.79 \%$ & $1.41 \%$ & $2.11 \%$ & $100.00 \%$ \\
\hline \multirow{2}{*}{ Gender } & Female & $25.38 \%$ & $49.23 \%$ & $21.54 \%$ & $3.08 \%$ & $0.77 \%$ & $100.00 \%$ \\
\hline & Male & $37.85 \%$ & $37.15 \%$ & $18.06 \%$ & $5.56 \%$ & $1.39 \%$ & $100.00 \%$ \\
\hline \multirow{2}{*}{ Status } & Academic & $37.05 \%$ & $45.82 \%$ & $13.55 \%$ & $2.39 \%$ & $1.20 \%$ & $100.00 \%$ \\
\hline & PhD & $29.07 \%$ & $39.92 \%$ & $23.64 \%$ & $6.20 \%$ & $1.16 \%$ & $100.00 \%$ \\
\hline
\end{tabular}

\section{Have you used an ebook relevant to your primary subject area?}

Participants who had not used an ebook provided by the UC Library were skipped to this question. As laid out in Table 16, 609 participants answered the question and 4 did not. Answers for this question were overwhelmingly Yes with $80.46 \%$. Only $12.15 \%$ had not used an ebook related to their primary subject area and $7.39 \%$ had not searched. Table 17 has the P-values for this question which show that there was no statistically significant relationship between answers given and any of the variable groups.

Table 16. Ebook Use for Primary Subject Area

\begin{tabular}{|c|c|c|}
\hline Answer & Frequency & Percentage \\
\hline Yes & 490 & $80.46 \%$ \\
\hline No & 74 & $12.15 \%$ \\
\hline I have not searched & 45 & $7.39 \%$ \\
\hline Grand Total & 609 & $100.00 \%$ \\
\hline
\end{tabular}

Table 17. Ebook Use for Primary Subject Area P-Values

\begin{tabular}{|c|c|c|}
\hline Variable & $\mathbf{P}$-Value & $\mathbf{P}<\mathbf{0 . 0 5}$ \\
\hline Age & 0.377945 & No \\
\hline Gender & 0.839072 & No \\
\hline Status & 0.49841 & No \\
\hline College & 0.171861 & No \\
\hline
\end{tabular}




\section{Please indicate in what format you would prefer that the University of Canterbury Library purchase the following types of resources:}

This question and definitions were adapted from Corlett-Rivera and Hackman's (2014) study apart from the definitions for Conference Proceedings and Literature which were added by the researcher. Figure 2 illustrates the format preference choices for different types of written material. Not all participants answered this question for each type of written material with the lowest number of answers being 603 for edited collections while 608 participants was the highest for Citation manuals and style guides. Literature and Scholarly monographs were preferred in print by the largest groups of participants with $55.35 \%$ and $44.30 \%$ respectively. Conference proceedings, general reference, specialized reference and citation manuals and style guides showed the largest preference for ebooks with $57.43 \%, 46.86 \%, 43.89 \%$ and $58.22 \%$ respectively. Edited collections had a different trend with the answers for print and ebook being fairly evenly split with $34.33 \%$ and $31.84 \%$ respectively. The No preference answer ranged for $16.64 \%$ for Literature through to $22.94 \%$ for general reference. The It depends answers ranged from $6.41 \%$ for Citation manuals and style guides through to $14.10 \%$ for edited collections. Figure 2 more clearly shows the preference trends outlined above. The full details

The P-value for format preference answers by type of book was 0.00000 meaning that the variations in format preference are statistically significant. The P-values for format preference for different types of written material and variable groups are shown in Table 18. Various different groups showed statistically significant results for certain types of written material but it was not uniform across the groups highlighting the differences in preference for each group. The Age variable group showed statistically significant results for all book types except edited collections and general reference. The Gender group showed no statistically significant results except for the Literature book type. The Status group showed significant results for Scholarly monographs, General reference, Specialized reference and Citation manuals and style guides, while by College, Conference, proceedings, Literature, Citation manuals and style guides and Specialized reference had significant results. Edited collections was the only book type that showed no statistically significant results across all variable groups and no book types had statistically significant results across all groups. The full details of each variable groups' statistically significant results, for format preferences by book type, are provided in Appendices 2 - 5. 
Figure 2. Format Preference for Different Types of Books

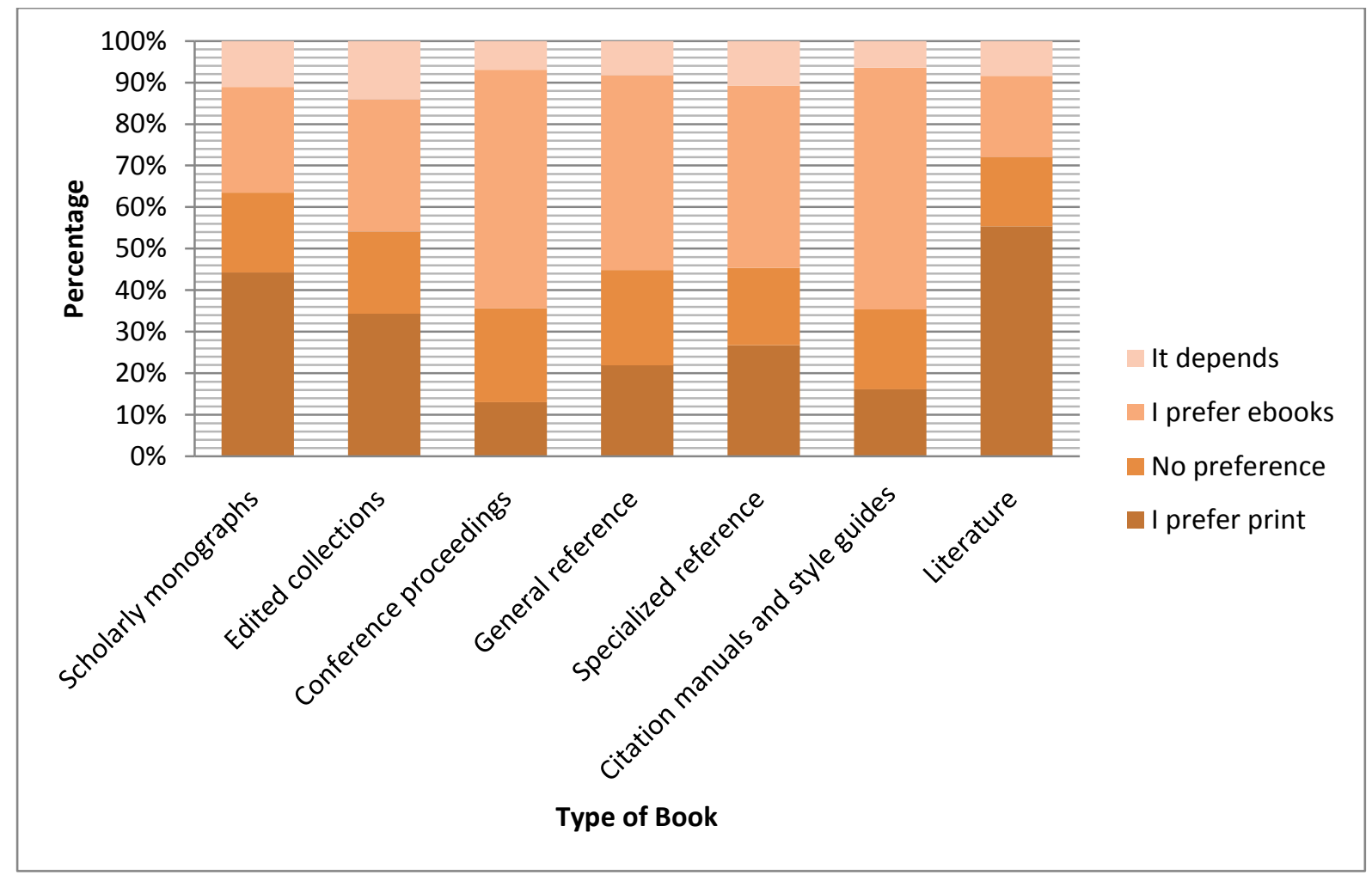

Table 18. Format Preference P-Values for Variable Groups

\begin{tabular}{|c|c|c|c|c|c|c|c|c|}
\hline \multirow[b]{2}{*}{ Type of Book } & \multicolumn{2}{|c|}{ Age } & \multicolumn{2}{|c|}{ Gender } & \multicolumn{2}{|c|}{ Status } & \multicolumn{2}{|c|}{ College } \\
\hline & P-Value & $\begin{array}{c}P< \\
0.05 \\
\end{array}$ & P-Value & $\begin{array}{l}P< \\
0.05 \\
\end{array}$ & P-Value & $\begin{array}{c}P< \\
0.05 \\
\end{array}$ & P-Value & $\begin{array}{l}P< \\
0.05 \\
\end{array}$ \\
\hline $\begin{array}{c}\text { Scholarly } \\
\text { monographs }\end{array}$ & 0.00782 & Yes & 0.11518 & No & 0.02506 & Yes & 0.75555 & No \\
\hline $\begin{array}{c}\text { Edited } \\
\text { collections }\end{array}$ & 0.05835 & No & 0.06653 & No & 0.61375 & No & 0.48476 & No \\
\hline $\begin{array}{l}\text { Conference } \\
\text { proceedings }\end{array}$ & 0.01029 & Yes & 0.65667 & No & 0.07283 & No & 0.01849 & Yes \\
\hline $\begin{array}{l}\text { General } \\
\text { reference }\end{array}$ & 0.25391 & No & 0.44797 & No & 0.03447 & Yes & 0.15377 & No \\
\hline $\begin{array}{l}\text { Specialized } \\
\text { reference }\end{array}$ & 0.03415 & Yes & 0.26981 & No & 0.04488 & Yes & 0.00347 & Yes \\
\hline $\begin{array}{l}\text { Citation manuals } \\
\text { and style guides }\end{array}$ & 0.00022 & Yes & 0.91539 & No & 0.018 & Yes & 0.02302 & Yes \\
\hline Literature & 0.00555 & Yes & 0.01852 & Yes & 0.06379 & No & 0.03194 & Yes \\
\hline
\end{tabular}




\section{When doing your academic work, how important are the following features? (If you have never used an ebook, how important would these features be if considering using one?)}

Not all participants chose to provide an answer for each feature with the number of answering participants ranging from 599 to 605 . The question was taken from Lamb's (2012) study. The full results of for this question are detailed in Appendix 6. As illustrated in Figure 3, the following features had an overwhelmingly important result with either Somewhat important or Very important chosen by most participants:

- Ability to find e-books in the Library catalogue or Library Search

- Ability to find e-books in search engines (e.g., Google, Yahoo)

- Ability to download the whole e-book to computer or laptop for later use

- Ability to download the book chapters or portions of the e-book to computer or laptop for later use

- Ability to search within the full-text of items

Three additional features showed a slightly less strong trend for important but with around $30 \%$ to $40 \%$ of participants choosing unimportant answers or neutral:

- Ability to annotate, bookmark or make notes

- Ability to link to a particular chapter

- Availability of a print copy of the same title from the Library

The final three features showed a much small importance result with the majority of participants choosing unimportance answers or Neutral:

- Ability to read on a mobile device (e.g., iPhone, iPad, Blackberry)

- Ability to read on a dedicated e-book reader, (e.g., Kindle, Sony Reader)

- Ability to download the whole ebook to a mobile device

The overall trend was for most of the features listed to be deemed important but with the three features related to mobile devices or e-readers having a majority of participants viewing them neutrally or as unimportant. The P-value for results indicated that there was a statistically significant relationship between the answers and the features importance level. 
Figure 3. Importance of Particular Ebook Features

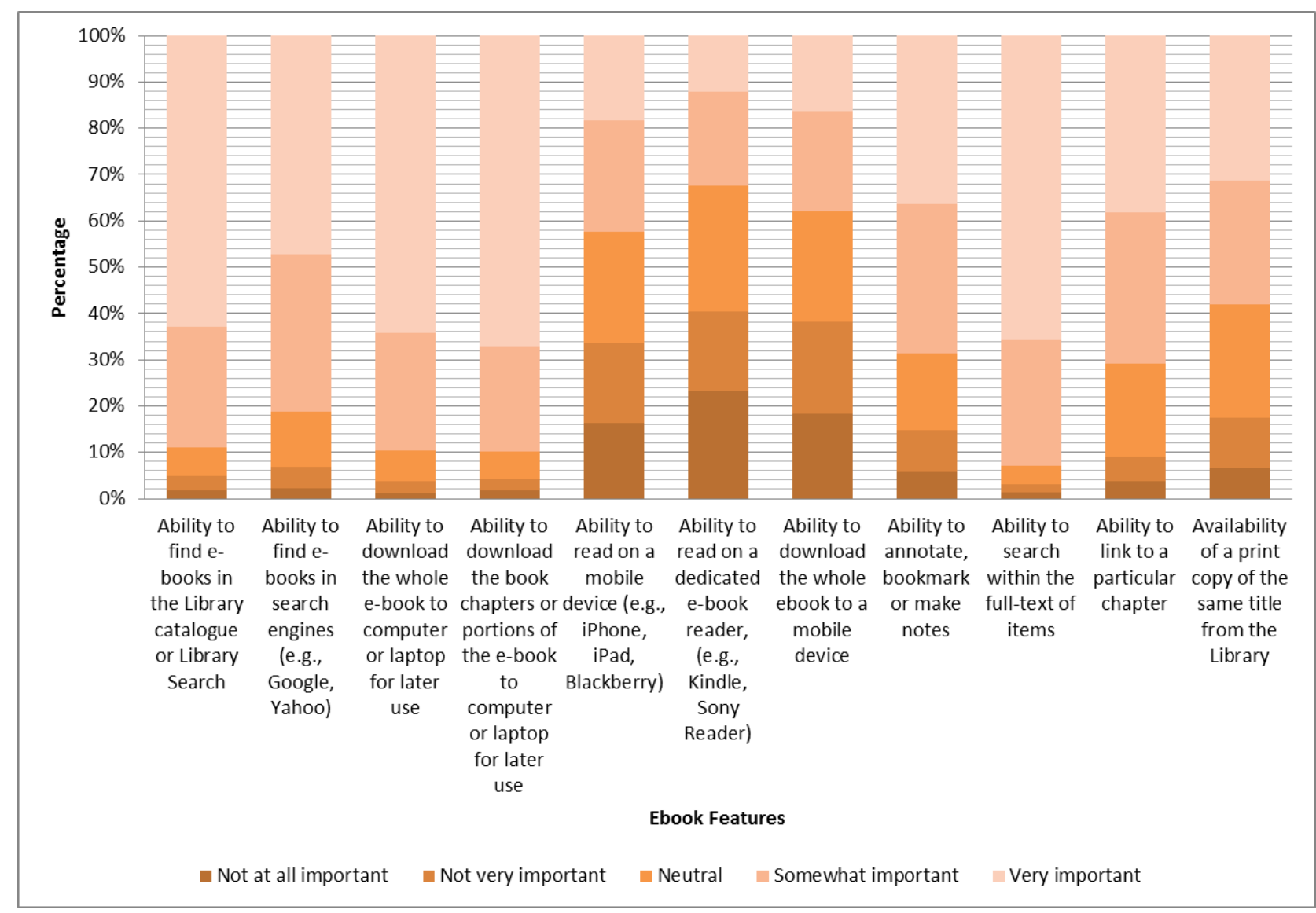

Table 19 lays out the P-values for the importance ranking of the various ebook features by variable group. From a total 44 Chi-square tests, 15 were significant and 29 were not. Ability to download the whole ebook to a mobile device was the only feature to have no statistically significant results; the rest of the features had one or two statistically significant results. The college group stands out with only one significant result whereas there other three variables groups have 4 or 5 significant results each.

Table 19. Importance of Particular Ebook Features by Variable Group P-Values

\begin{tabular}{|c|c|c|c|c|c|c|c|c|}
\cline { 2 - 8 } \multicolumn{1}{c|}{} & \multicolumn{2}{c|}{ Age } & \multicolumn{2}{c|}{ Gender } & \multicolumn{2}{c|}{ Status } & \multicolumn{2}{c|}{ College } \\
\hline Type of Book & P-Value & $\mathbf{P}<0.05$ & P-Value & $\begin{array}{c}P< \\
0.05\end{array}$ & P-Value & P $<0.05$ & P-Value & $\begin{array}{c}P< \\
0.05\end{array}$ \\
\hline $\begin{array}{c}\text { Ability to find e- } \\
\text { books in the } \\
\text { Library catalogue } \\
\text { or Library Search }\end{array}$ & 0.656529 & No & 0.273931 & No & 0.085882 & No & 0.023904 & Yes \\
\hline $\begin{array}{c}\text { Ability to find e- } \\
\text { books in search } \\
\text { engines (e.g., } \\
\text { Google, Yahoo) }\end{array}$ & 0.068436 & No & 0.021627 & Yes & 0.013113 & Yes & 0.53483 & No \\
\hline
\end{tabular}




\begin{tabular}{|c|c|c|c|c|c|c|c|c|}
\hline $\begin{array}{l}\text { Ability to } \\
\text { download the } \\
\text { whole e-book to } \\
\text { computer or } \\
\text { laptop for later } \\
\text { use }\end{array}$ & 0.029404 & Yes & 0.445049 & No & 0.131279 & No & 0.077254 & No \\
\hline $\begin{array}{c}\text { Ability to } \\
\text { download the } \\
\text { book chapters or } \\
\text { portions of the e- } \\
\text { book to } \\
\text { computer or } \\
\text { laptop for later } \\
\text { use }\end{array}$ & 0.67316 & No & 0.01068 & Yes & 0.533334 & No & 0.182334 & No \\
\hline $\begin{array}{l}\text { Ability to read on } \\
\text { a mobile device } \\
\text { (e.g., iPhone, } \\
\text { iPad, Blackberry) }\end{array}$ & 0.000871 & Yes & 0.024682 & Yes & 0.17623 & No & 0.266991 & No \\
\hline $\begin{array}{l}\text { Ability to read on } \\
\text { a dedicated e- } \\
\text { book reader, } \\
\text { (e.g., Kindle, } \\
\text { Sony Reader) }\end{array}$ & 0.053643 & No & 0.506695 & No & 0.011892 & Yes & 0.770455 & No \\
\hline $\begin{array}{c}\text { Ability to } \\
\text { download the } \\
\text { whole ebook to a } \\
\text { mobile device }\end{array}$ & 0.13048 & No & 0.210419 & No & 0.497134 & No & 0.448127 & No \\
\hline $\begin{array}{c}\text { Ability to } \\
\text { annotate, } \\
\text { bookmark or } \\
\text { make notes }\end{array}$ & 0.00862 & Yes & 0.03721 & Yes & 0.25746 & No & 0.72082 & No \\
\hline $\begin{array}{l}\text { Ability to search } \\
\text { within the full- } \\
\text { text of items }\end{array}$ & 0.01073 & Yes & 0.41525 & No & 0.00294 & Yes & 0.24641 & No \\
\hline $\begin{array}{l}\text { Ability to link to } \\
\text { a particular } \\
\text { chapter }\end{array}$ & 0.23422 & No & 0.012 & Yes & 0.00335 & Yes & 0.05368 & No \\
\hline $\begin{array}{l}\text { Availability of a } \\
\text { print copy of the } \\
\text { same title from } \\
\text { the Library }\end{array}$ & 0.6757 & No & 0.21993 & No & 0.04885 & Yes & 0.10652 & No \\
\hline
\end{tabular}




\section{Select your response to the statements using the following scale:}

The results for this question are summarised in Figure 4 but for the full results see Appendix 7. Between 602 and 611 participants chose an answer for the statements in this question. The following statements showed a very similar and symmetrical distribution with around $10 \%$ each for Strongly agree and Strongly disagree and around 25\% each for Agree, Neutral and Disagree:

- Ebooks are as good as print books

- If available, I would prefer to use ebooks as resources rather than print books for teaching or research

Several other statements showed similar distribution of answers. Two questions had around $60-70 \%$ of answers of Disagree or Strongly disagree with only around 10\% for Agree and Strongly agree:

- The library should continue to purchase books in print format only and not buy ebooks

- The library should purchase book titles in ebook format instead of print format

Additionally, two statements showed the opposite pattern with only around $10 \%$ disagreement and around $70 \%$ agreement:

- The library should purchase book titles in both print and ebook format

- Ebooks are suitable resources for my teaching and/or research

The remaining three questions had small disagreement results of around $3 \%-15 \%$ and with agreement of around $40 \%-50 \%$ and with large Neutral results of also around $40 \%-50 \%$.

- Ebooks provided by the University of Canterbury Library are easy to find

- Ebooks are accessible in the place(s) where I most need to use them

- When needed, library assistance with using ebooks is readily available 


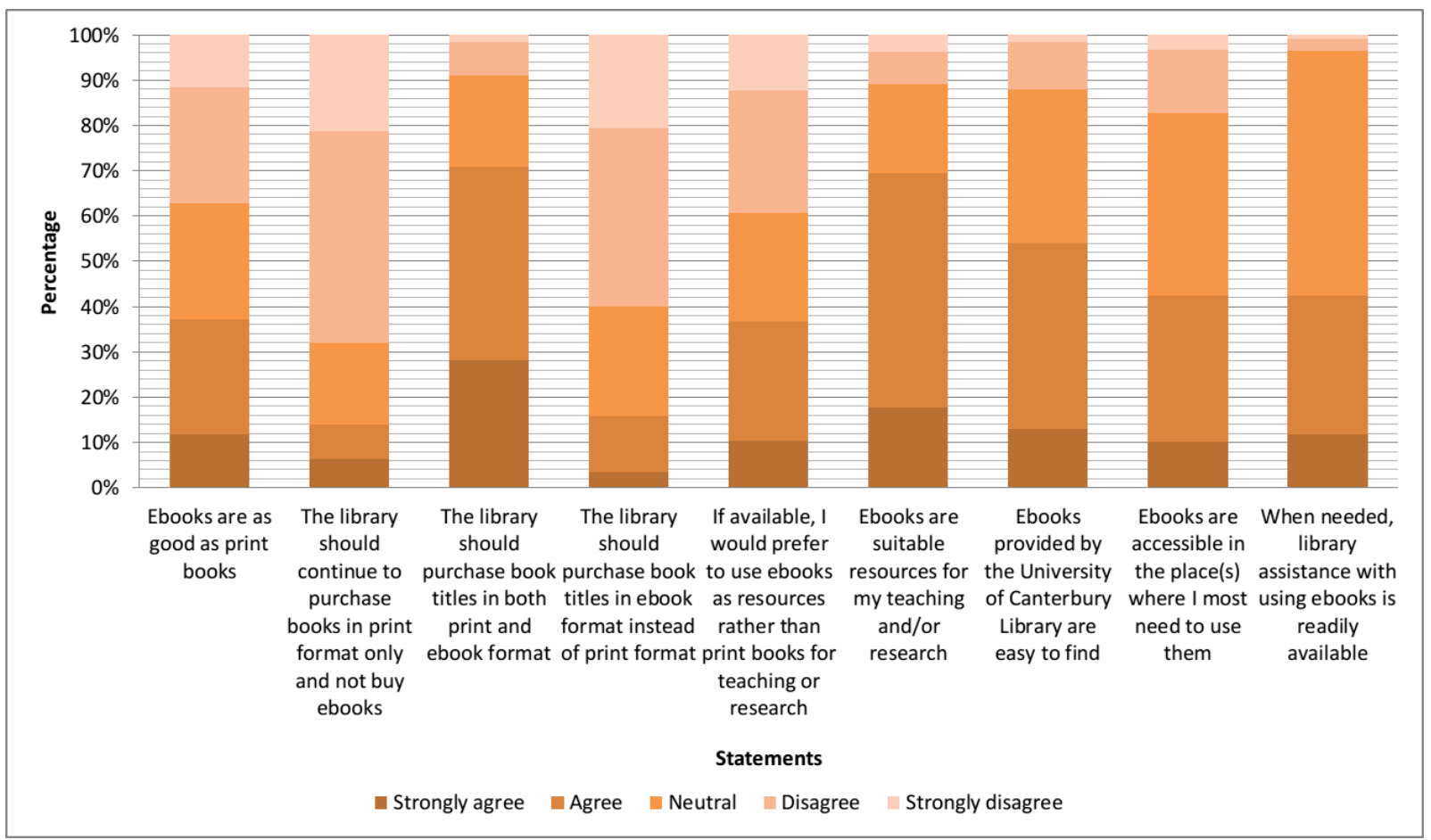

The P-value for the results for the whole sample was 0.00001 meaning the distribution of answers was statistically significant. The P-values for the variable groups' answers to this question are outlined in Table 20 . There were 13 , out of a possible 36, statistically significant relationships between different groups and particular statements. The Age group showed the most statistically significant results with six out of the nine statements while Gender had the least with only one significant result. By Status there were four significant results and finally the College group showed two significant results.

Table 20. Opinion of Ebooks Variable Group P-Values

\begin{tabular}{|c|c|c|c|c|c|c|c|c|}
\cline { 2 - 9 } \multicolumn{1}{c|}{} & \multicolumn{2}{c|}{ Age } & \multicolumn{2}{c|}{ Gender } & \multicolumn{2}{c|}{ Status } & \multicolumn{2}{c|}{ College } \\
\hline Question & P-Value & $\mathbf{P}<0.05$ & P-Value & $\mathbf{P}<0.05$ & P-Value & P $<0.05$ & P-Value & P $<0.05$ \\
\hline $\begin{array}{c}\text { Ebooks are as good } \\
\text { as print books }\end{array}$ & 0.000205 & Yes & 0.487678 & No & 0.006726 & Yes & 0.001162 & Yes \\
\hline $\begin{array}{c}\text { The library should } \\
\text { continue to } \\
\text { purchase books in } \\
\text { print format only } \\
\text { and not buy ebooks }\end{array}$ & 0.47597 & No & 0.370155 & No & 0.221738 & No & 0.492168 & No \\
\hline $\begin{array}{c}\text { The library should } \\
\text { purchase book titles } \\
\text { in both print and } \\
\text { ebook format }\end{array}$ & 0.049974 & Yes & 0.119254 & No & 0.00 & Yes & 0.067447 & No \\
\hline $\begin{array}{c}\text { The library should } \\
\text { purchase book titles } \\
\text { in ebook format } \\
\text { instead of print }\end{array}$ & 0.026337 & Yes & 0.759621 & No & 0.09 & No & 0.098575 & No \\
\hline
\end{tabular}




\begin{tabular}{|c|c|c|c|c|c|c|c|c|}
\hline format & & & & & & & & \\
\hline $\begin{array}{l}\text { If available, I would } \\
\text { prefer to use } \\
\text { ebooks as resources } \\
\text { rather than print } \\
\text { books for teaching } \\
\text { or research }\end{array}$ & 0.017058 & Yes & 0.379697 & No & 0.005199 & Yes & 0.005316 & Yes \\
\hline $\begin{array}{l}\text { Ebooks are suitable } \\
\text { resources for my } \\
\text { teaching and/or } \\
\text { research }\end{array}$ & 0.016712 & Yes & 0.312833 & No & 0.021953 & Yes & 0.300426 & No \\
\hline $\begin{array}{l}\text { Ebooks provided by } \\
\text { the University of } \\
\text { Canterbury Library } \\
\text { are easy to find }\end{array}$ & 0.015819 & Yes & 0.000312 & Yes & 0.491266 & No & 0.153433 & No \\
\hline $\begin{array}{c}\text { Ebooks are } \\
\text { accessible in the } \\
\text { place(s) where I } \\
\text { most need to use } \\
\text { them }\end{array}$ & 0.28721 & No & 0.08142 & No & 0.28308 & No & 0.23228 & No \\
\hline $\begin{array}{l}\text { When needed, } \\
\text { library assistance } \\
\text { with using ebooks is } \\
\text { readily available }\end{array}$ & 0.26137 & No & 0.18346 & No & 0.25707 & No & 0.44554 & No \\
\hline
\end{tabular}

\section{Which of the following would make ebooks more suitable for} use in your subject area for teaching and/or research? (select all that apply)

Table 21, illustrates the percentage of participants from the whole population who chose a particular factor as being one that would make ebooks more suitable for use in the subject area. The percentages for particular answers ranged from $84.67 \%$ for Ability to download to $16.97 \%$ for Better training and instruction.

Table 20. Factors that Make Ebooks More Useful

\begin{tabular}{|c|c|c|}
\hline Question & $\begin{array}{c}\text { Number of participants who } \\
\text { chose this }\end{array}$ & $\begin{array}{c}\text { Percentage of total } \\
\text { population }\end{array}$ \\
\hline $\begin{array}{c}\text { Greater breadth and depth of } \\
\text { collection }\end{array}$ & 325 & $53.02 \%$ \\
\hline Ability to download & 519 & $84.67 \%$ \\
\hline $\begin{array}{c}\text { Less restrictions on printing } \\
\text { and copying }\end{array}$ & 407 & $66.39 \%$ \\
\hline
\end{tabular}




\begin{tabular}{|c|c|c|} 
More current titles & 291 & $47.47 \%$ \\
\hline $\begin{array}{c}\text { Better training and } \\
\text { instruction }\end{array}$ & 104 & $16.97 \%$ \\
\hline Multi-user access & 220 & $35.89 \%$ \\
\hline $\begin{array}{c}\text { Better research tools (e.g., } \\
\text { annotation) }\end{array}$ & 287 & $46.82 \%$ \\
\hline Multimedia capabilities & 108 & $17.62 \%$ \\
\hline Mobile device accessibility & 142 & $23.16 \%$ \\
\hline Other (please explain) & 63 & $10.28 \%$ \\
\hline
\end{tabular}

63 participants, or $10.28 \%$ percent, chose the Other option. Their answers are summarised below. Some answers were actually already options in the question. A number of answers contained multiple factors that would make ebooks more suitable bringing the total below to 67 .

Answers that were already options in the question:

- Greater breadth and depth of collection

- Ability to download

- Mobile device accessibility

- Multi-user access

- Better research tools (e.g., annotation)

Other answers:

- Better layout/format/interface

- Ability to search full-text

- Irrelevant/incomprehensible

- Easy to find

- Easy to navigate

- Compatibility with other software

- Speed of access/use

- No Digital Rights Management (DRM)

- Fewer loan time restrictions

- Ability access on own computer

- Better reproduction of artworks

- Realistic prices from publishers

- Fewer restrictions

- Accessibility options for people with disabilities (1) 


\section{Select your response to the statements below using the following scale:}

The number of responses for each statement in this question ranged from 605 to 612 . The aim of this question was to test to what extend the first five factors correlate with the sixth factor of intention to increase ebook use. Participants were asked to give a response on a 5-point scale from Strongly agree through to Strongly disagree. The statements were:

- Using print books completely satisfies all my teaching and/or research needs

- Using an ebook is more effective than using a print book for my teaching and/or research

- Learning how to use ebooks takes a lot of time and effort

- I like to experiment with new information technology

- People I respect think that I should switch from print books to ebooks

- I intend to increase my use of ebooks

They represented the following factors affecting switching to ebooks identified by Sanford's (2013) study:

- Satisfaction With Print Books

- Relative Advantage of Ebooks

- Switching Cost

- Personal Innovativeness With IT

- Subjective Norm Toward Switching to Ebooks

- Switching to Ebook Intention

Figure 5 summarises the Agreement (Agree + Strongly agree) percentages for the first 5 statements for the whole population compared with the same percentages but only for those participants who were in agreement with the sixth statement about intending to increase usage of ebooks who represent $51.72 \%$ of the total population. A full breakdown of the participants' responses is available in Appendix 8. What is of interest here is the differences between the whole population and those who intend to increase their use of ebooks with regard to the five factors. It does not matter if the percentage is lower or higher as this depends on whether or not the factors negatively or positively affect intention to switch to ebooks.

Those participants intending to increase their use of ebooks were $8.57 \%$ less satisfied with print books. They were $15.45 \%$ more likely to consider ebooks to have a Relative Advantage which was the largest percentage difference from the whole population. The difference for Switching Cost, or the perceived difficulty of learning how to use ebooks, was negligible with only $0.32 \%$ difference. The difference for Personal Innovativeness, or how much participants like to experiment with new technology, was $8.84 \%$ while the difference for Selective Norm Toward Switching to Ebooks, that is, their perception that people they respect think they should switch to ebooks, was $5.63 \%$. The advantages of ebooks seemed to have the strongest correlation with intention to switch to ebooks while all the other factors except the Switching cost seem to have some correlation. Table 22 illustrates the P-values for the first five factors as compared with intention to switch to ebooks. All statements showed a statistically significant result according to their P-values. 
Figure 5. Factors Affecting Switching to Ebooks

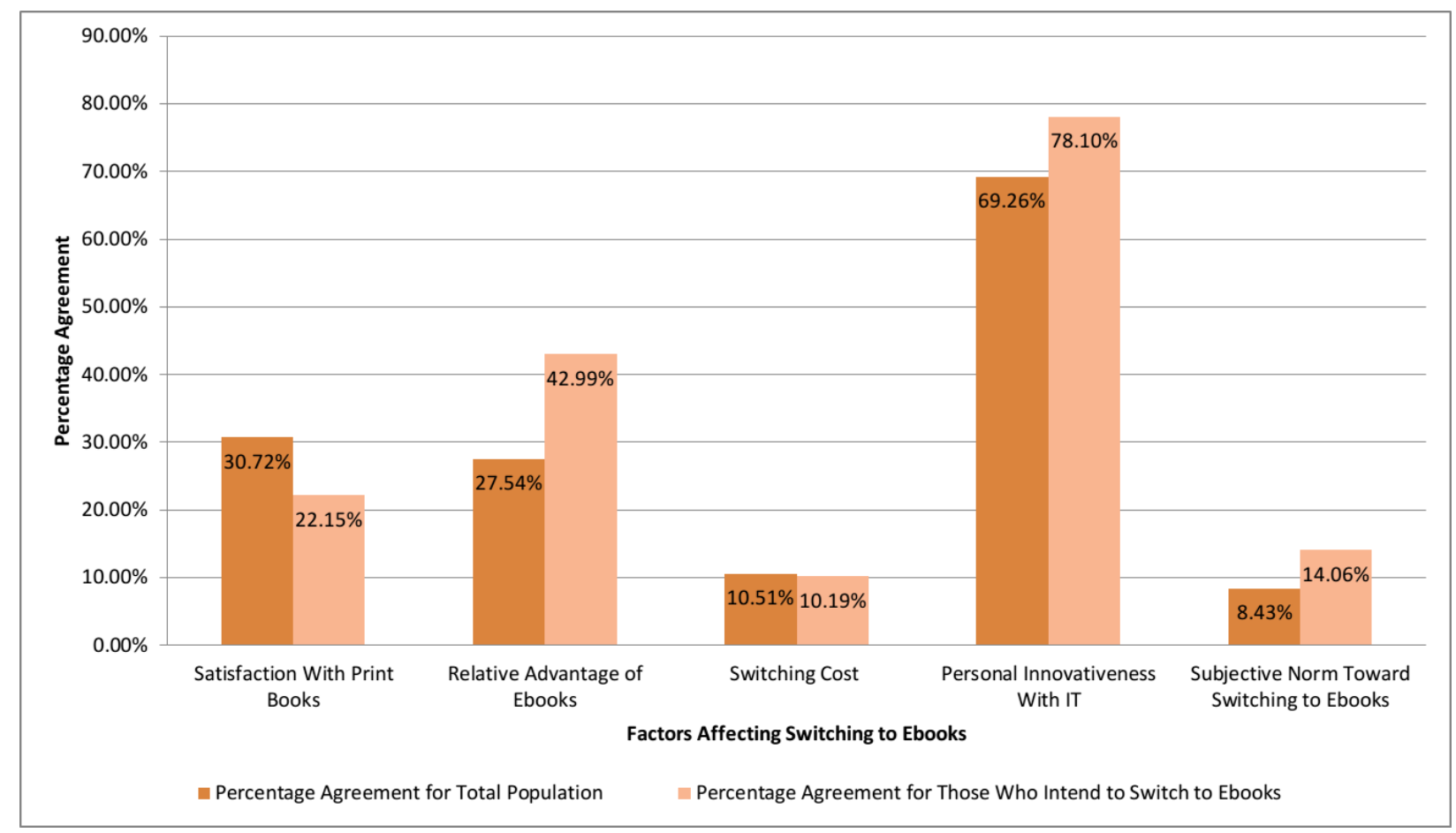


Table 21. Factors Affecting Switching to Ebooks P-Values

\begin{tabular}{|c|c|c|c|}
\hline \multicolumn{2}{|c|}{ Factors Affecting Switching to Ebooks } & P-Value & $P<0.05$ \\
\hline $\begin{array}{l}\text { Satisfaction With } \\
\text { Print Books }\end{array}$ & $\begin{array}{c}\text { Using print books completely } \\
\text { satisfies all my teaching and/or } \\
\text { research needs }\end{array}$ & 0.00001 & Yes \\
\hline $\begin{array}{c}\text { Relative Advantage } \\
\text { of Ebooks }\end{array}$ & $\begin{array}{c}\text { Using an ebook is more } \\
\text { effective than using a print } \\
\text { book for my teaching and/or } \\
\text { research }\end{array}$ & 0.00001 & Yes \\
\hline Switching Cost & $\begin{array}{l}\text { Learning how to use ebooks } \\
\text { takes a lot of time and effort }\end{array}$ & 0.000031 & Yes \\
\hline $\begin{array}{c}\text { Personal } \\
\text { Innovativeness } \\
\text { With IT }\end{array}$ & $\begin{array}{l}\text { I like to experiment with new } \\
\text { information technology }\end{array}$ & 0.00001 & Yes \\
\hline $\begin{array}{l}\text { Subjective Norm } \\
\text { Toward Artifact } \\
\text { Switching }\end{array}$ & $\begin{array}{c}\text { People I respect think that I } \\
\text { should switch from print books } \\
\text { to ebooks }\end{array}$ & 0.00001 & Yes \\
\hline
\end{tabular}

\section{Please add any other comments you may have about your use of ebooks in the box below.}

167 participants chose to leave a comment in the last question that had a free text answer box. However, many of the answers contained multiple comments resulting in a total 307 comments. The comments were divided into the following categories as shown in Table 23.

Table 22. Categorised Participant Comments

\begin{tabular}{|l|c|c|c|c|c|}
\cline { 2 - 6 } \multicolumn{1}{c|}{} & Positive & Negative & General & Misc. & Total \\
\hline Comments & 64 & 119 & 116 & 8 & 307 \\
\hline Percentage & $20.85 \%$ & $38.76 \%$ & $37.79 \%$ & $2.61 \%$ & $100.00 \%$ \\
\hline
\end{tabular}


The negative comments about ebooks were greater in number with $38.76 \%$ than the positive comments with only $20.85 \%$. The general comments about ebooks were about the same in number as the negative comments with $37.79 \%$ while a further $2.61 \%$ of comments were put under miscellaneous. Various themes were identified under each category as laid out below with their percentage of the total comments:

Positive Comments (Total 20.85\%):

- Ease of access (9.12\%)

- Full-text search (4.23\%)

- Portability/save space (2.61\%)

- Prefer ebook (reason not stated) $(1.95 \%)$

- Good for distance students / regional staff (1.30\%)

- Cheaper than print $(0.65 \%)$

- Easy to find $(0.33 \%)$

- Easy to navigate $(0.33 \%)$

- Intend to increase use of ebooks (reason not stated) (0.33\%)

Negative Comments (Total 38.76\%):

- Prefer print (reason not stated) (9.77\%)

- Layout/format/interface/software problematic (6.19\%)

- Don't like reading screens (4.56\%)

- Hard on eyes/already too much screen time

- Harder to comprehend content

- Too many loan time restrictions (3.58\%)

- Digital Rights Management (DRM) problematic (2.28\%)

- Lack of engagement with physical senses (1.63\%)

- Not good for figures and diagrams (1.63\%)

- Too many restrictions (restrictions not specified) (1.30\%)

- Ebooks require internet connection and power (less portable) $(1.30 \%)$

- Not good for visual arts $(0.98 \%)$

- Lack of current titles (0.98\%)

- Restrictions on downloading $(0.65 \%)$

- Poor breadth and depth of collection (0.65\%)

- Print easier to flick through (0.65\%)

- Potential for file format issues $(0.33 \%)$

- Cannot browse ebooks on the shelf $(0.33 \%)$

* General Comments (Total 37.79\%):

- Importance of being able to print and copy (5.21\%)

- And less restrictions

- Importance of ability to download (5.21\%)

- Print for whole book or concentrated study, ebook for quick use (4.89\%)

- Importance of multi-user/unlimited access (4.89\%)

- Preference depends on use (3.26\%)

- Preference depends on type of written material (2.93\%)

- Like to use both print and ebooks (1.95\%)

- Importance research tools (e.g., annotation, highlighting) (1.95\%) 
- Importance of availability as PDFs (1.95\%)

- Breadth and depth of depends on subject area $(0.98 \%)$

- Importance of mobile device accessibility $(0.98 \%)$

- Ebooks for teaching print for research $(0.65 \%)$

- Library should let people know cost of ebook purchase so they can decide whether to buy themselves $(0.65 \%)$

- E-readers important $(0.65 \%)$

- More titles in subject area available in ebook than print $(0.65 \%)$

- Realistic prices from publishers needed $(0.33 \%)$

- Ebooks for research print for teaching $(0.33 \%)$

- Don't like reading computer screen but kindle great $(0.33 \%)$

- Have limited computer storage for ebooks at home $(0.33 \%)$

Miscellaneous Comments (Total 2.61\%):

- Limited or no use of books in any format $(0.98 \% 0$

- UC internet speed and download limit need to increase if ebooks are the future $(0.33 \%)$

- Please don't demolish the library (0.33\%)

- Should specify what exactly you mean by "e-book". I completed this survey including all digital forms of literature as ebooks (e.g., PDFs) (0.33\%)

- Some more international books would be very helpful for my research. Perhaps through some kind of inter-library loans? (0.33\%)

- I guess there are a high correlation between the age and the use of new technologies. (0.33\%)

\section{Discussion}

The discussion section will look at the research questions and use the results to answer them. To determine whether or not age, gender, status or college affects users' perception of and use of ebooks Chi-square tests were conducted with answers to most of the questions in the survey to see if there was a statistically significant relationship, which is the same method used by Posigha (2012).

\section{Are users aware of, and using, the ebook collections at the University of Canterbury and, if so, what factors affect how they perceive and use ebooks?}

The results show clearly that overwhelming majority, $91.82 \%$, of respondents are aware of the ebook collections at UC. This result is very similar to Lamb's (2012) study, from which this question was taken, that found that $89 \%$ of academic staff at Waikato University were aware of the university's ebook collections. Borchert, et al. (2009) also found that a majority of students and staff at two Queensland universities were aware of their libraries ebook collections although the figure was only between $70 \%$ and $80 \%$. Lamb (2012) stated that the relatively higher level of awareness in his study could be due to the increasing awareness of e-resources in the gap between his study and 
earlier studies which seems plausible. However, there is no discernible gap between awareness Lamb's 2012 study and this 2015 study indicating that the trend for greater awareness may have reached its full extent or slowed down. It's plausible that perhaps around $10 \%$ of people will always or at least for some time choose to ignore e-resources and ebooks in general in favour of more traditional print mediums. Nevertheless, this result does show that awareness is very strong at UC although there is certainly room for a campaign to bring ebook collections to the attention of the $8 \%$ of library users who are not yet aware of the collections. It would be useful to know what percentage of the universities academics and PhD students never use the library or any of its resources as this might correlate highly with a lack of awareness of the ebook collections.

A follow up question, also taken from Lamb's (2012) study sort to find out how often participants used the ebooks from the university's library. The results showed that the vast majority of participants had used a library ebook at least once with only $14.06 \%$ having never used an ebook. Half of participants had used a library ebook a couple of times and a further $27.58 \%$ had used one often. These percentages showed slightly higher ebook use than found in Lamb's study where $16 \%$ had never used an ebook despite being aware. Also the percentage of people who had used an ebook often in the University of Waikato study was only $18 \%$ compared with $27 \%$ in this study. The results compare very favourably with Corlett-Rivera and Hackman's (2014) study that found between $31 \%$ and $41 \%$ of users had never used an ebook from the university's library although their results had not previously filtered out those who were unaware of the libraries ebook collections. However, even if we include the 50 people who answered no to the awareness question in the total for those who have never used an ebook we still only get $21.08 \%$ which is still significantly lower than Corlett-Rivera and Hackman's (2014) results but is similar to Borchert, et al. (2009) who found that around $20 \%$ of user had never used an ebook. Overall, the usage of ebooks at UC seems to be comparable or higher than previous studies indicating the ebook usage in academic libraries may be increasing, although a significant minority have still never used an ebook from the university library although they may well have used one from elsewhere.

Another question in the survey looked at whether or not participants had used an ebook relevant to their subject area. This question was also taken from Lamb's (2012) study and did not specify that the ebooks were in the UC Library collection. A significant number of participants, $80.46 \%$, had used an ebook relevant to their subject area. Interestingly we get a number of around $20 \%$ having not used an ebook in their subject area which is comparable to the figure above for those who have not used an ebook from the university Library. We could surmise then that the people who are not using the UC Library ebook collections are also not using ebooks sourced elsewhere. It would be useful to test this in any follow up survey especially if it was geared towards assessing to what degree the ebook collection meets the needs of its users. This number was significantly lower, however than that of Lamb's study that had $94 \%$ having used an ebook relevant to their subject area. Lamb's study had filtered out the participants who were not aware of the universities ebook collections for this question but the UC study did not, however, if we filter out those not aware of the ebook collections at UC with a pivot table we still get a lower percentage of $83.90 \%$ of participants having used an ebook relevant to their subject area.

Following on from Lamb's (2012) study, a question was included in the survey that asked participants about the importance of certain ebook features. The results in both studies are remarkably similar. The following features stood out strongly as important features for the majority of participants:

- Ability to find e-books in the Library catalogue or Library Search 
$88.91 \%$ of participants at UC and $90 \%$ of participants at Waikato ranked this as important. There was a minor mistake in this question in that Library Search, Waikato's branding of the Summon discovery layer tool, should have been rewritten as MultiSearch, UC's branding for Summon. This mistake does not seem to have affected the results. As Lamb (2012) pointed out, this result shows that the Library's search functionality is highly valued for finding ebooks.

- Ability to find e-books in search engines (e.g., Google, Yahoo)

$81.29 \%$, compared with $77 \%$ in the previous study, ranked this as important showing that users also highly value general internet search engines for finding ebooks although to a lesser extent than the Library search functions.

- Ability to download the whole e-book to computer or laptop for later use

$89.52 \%$ and $86 \%$ thought this feature was important in the two studies. As shall be discussed later a number of the qualitative answers at the end of the survey indicated that ability to download was important or that it was frustrating when they could not download ebooks.

- Ability to download the book chapters or portions of the e-book to computer or laptop for later use

Not surprisingly this feature garnered very similar responses to the above with $89.92 \%$ and $87 \%$ respectively for the two studies. Being able to download is clearly a major advantage when using ebooks and is highly valued by participants in both studies.

- Ability to search within the full-text of items

The ability to do full-text searches was ranked as being highly important in both studies with $92.87 \%$ and $91 \%$ respectively. Again this is one of the major advantages of ebooks and was mentioned in a number of the comments at the end of the survey.

Three additional features were also considered important but to a lesser extent:

- Ability to annotate, bookmark or make notes

$68.61 \%$ of participants ranked this feature as important compared with $70 \%$ for Lamb's (2012) study. This ability is clearly important but was mentioned only a few times in the comments section of the survey. Quite a few comments indicated that ebooks were inferior to print for concentrated study and that they were harder to interact with and comprehend. While research features like making notes may help it would seem that they are not enough to motivate some users to switch from print to ebooks.

- Ability to link to a particular chapter

$70.93 \%$ of participants viewed this as important which was less than the $78 \%$ at Waikato indicating that it is valued at UC but to a lesser extent than at Waikato. This is a feature that speeds up use of ebooks and also makes them more useful for teaching whereby the academic can link straight to a particular chapter when directing students to read it. A number of comments mentioned that it was faster to find certain sections in a print book than an ebook meaning this feature is an important one because without it can be much slower to scroll through many pages than it is to open a book at a certain page. 
- Availability of a print copy of the same title from the Library

$57.95 \%$ of participants ranked this as important while $52 \%$ in the previous study did. As Lamb (2012) pointed out having books available in both formats may help with the introduction of ebooks if users' feel they can fall back on print if needed. A number of comments indicated that participants use ebooks and print books for different purposes. Ebooks are preferred for quick use while print is often preferred for concentrated reading. It may well be that many participants would like both formats so they can use them for different purposes.

Finally, three features showed much smaller importance percentages comparable to their unimportance percentages:

- Ability to read on a mobile device (e.g., iPhone, iPad, Blackberry)

$42.38 \%$ of participants ranked this as important compared with $54 \%$ in Lamb's (2012) study. You would expect that as mobile devices become cheaper and more prevalent that this feature would become more important but it seems to be the opposite according to this result. It may be that casual use of ebooks on mobile devices is increasing but that academic ebooks are still read mostly on computers.

- Ability to read on a dedicated e-book reader, (e.g., Kindle, Sony Reader)

Even more surprising was that the ability to read ebooks on an e-reader was only given an importance ranking of $32.40 \%$, while its unimportance ranking was actually higher with $40.33 \%$. Lamb's (2012) study found a similar result with $30 \%$ importance compared with $36 \%$ unimportance. In both studies there were large percentages of neutral answers to this feature. The results of the UC and Waikato study are at variance to other previous studies that found that e-reader access was important for ebook use (Corlett-Rivera \& Hackman, 2014; Savova \& Garsia, 2012; Slater, 2010). This perhaps points to a regional variation in New Zealand academic contexts. It would be useful in a future study to examine how e-reader ownership in New Zealand compares to ownership overseas and particularly in the United States.

- Ability to download the whole ebook to a mobile device

This feature was given $37.98 \%$ importance compared with slightly higher unimportance ranking of $38.31 \%$. The Waikato study had a higher importance ranking of $44 \%$ for this question. This is not a surprising result given the comparatively low number of participants who think it is important to be able to read ebooks on an e-reader. Again though this result indicates that mobile devices might actually be decreasing in importance for ebook use, in New Zealand.

The question with opinion statements showed a range of opinion with regard to ebooks. Some statements were agreed with by the majority of participants while others were not revealing that participants still have very mixed feelings about ebooks. The following to statements were agreed with the most strongly, with $70.74 \%$ and $69.74 \%$ agreement percentages respectively.

- The library should purchase book titles in both print and ebook format

- Ebooks are suitable resources for my teaching and/or research

This is a similar result to Lamb's (2012) study with $72 \%$ for the statement about purchasing ebooks in both formats, showing that having access to both formats is highly valued. The statement about suitability for teaching and/or research was a modified version of Lamb's statement that referred 
only to teaching as his study included only academics. Since this study also included PhD students it was necessary to change the question to include research. Lamb's statement only received $50 \%$ agreement. No direct comparison is possible here as the questions are different. However, it is of interest to note, as will be discuss later, that academics agreed with this statement about $10 \%$ less often than PhD students although still at a higher rate than the Waikato study. It may be that academics are increasingly accepting ebooks for teaching or the difference may be explained by a higher acceptance for research than teaching. Further investigation is needed to clarify this point.

Three statements had higher agreement than disagreement rankings but also with a high percentage of neutral answers indicating participants were undecided.

- Ebooks provided by the University of Canterbury Library are easy to find

$53.95 \%$ agreed with this statement but a further $33.88 \%$ were neutral. This is a comparatively higher result than that of Lamb's (2012) study that found only $43 \%$ agreement with $32 \%$ neutral. We could tentatively conclude that ebooks are easier for users to find at UC than at Waikato 2 years ago. As noted by Lamb this result is significant when paired with the high percentage of participants who rated being able to find ebooks via library search functions as important. Clearly work needs to be done at UC to make the ebook collections easier to find or to educate users on how to find them.

- Ebooks are accessible in the place(s) where I most need to use them

42.31\% of participants agreed with this statement but almost the same percentage of participants, 40.33\% were neutral on this statement again indicating that users are undecided. Lamb's (2012) study found $38 \%$ agreement with this statement and $35 \%$ neutral, so they UC result is a little more positive than the Waikato result.

- When needed, library assistance with using ebooks is readily available

$42.36 \%$ of users agreed that library assistance was readily available, which is positive compared to the only $3.49 \%$ who disagreed. However, over half the participants, with $54.15 \%$ were neutral on this statement. This probably indicates that they have not asked for help before in many cases. It again indicates that better promotion of the availability of help with accessing ebooks is needed on behalf of the library. Lamb's (2012) result was slightly more positive with $44 \%$ agreement and only $49 \%$ neutral indicating that perhaps the Waikato library is a little better than UC at promoting help with accessing ebooks.

The following two statements had a very evenly spread distribution of answers with about the same number of participants ranking them as important as those who ranked them as unimportant and with about a quarter of participants being neutral.

- Ebooks are as good as print books

Disagreement and agreement for this statement were both $37.21 \%$ while Lamb's (2012) study received a higher agreement rating of $43 \%$ compared to $31 \%$ disagreement. The results for both studies show that participants are by no means convinced that ebooks are as good as print.

- If available, I would prefer to use ebooks as resources rather than print books for teaching or research 
As with another statement above this statement was reworded to include research as well as teaching, whereas Lamb's (2012) original only referred to teaching. A greater percentage of participants disagreed with this statement, with $39.28 \%$ compared to $36.82 \%$ agreement. Lamb's study had a relatively more positive response with $38 \%$ agreement and only $25 \%$ disagreement. These results indicate a slightly more negative view of ebooks at UC than at Waikato.

The final two statements were strongly disagreed with.

- The library should continue to purchase books in print format only and not buy ebooks

$68.04 \%$ of participants strongly disagreed with this statement, which is an endorsement of buying ebooks as well as print books. This trend was even more strongly pronounced at Waikato with $73 \%$ disagreement.

- The library should purchase book titles in ebook format instead of print format

$59.93 \%$ of participants disagreed with this statement compared with $60 \%$ in Lamb's (2012) study. Again these results show that participants are by no means convinced that ebooks should replace print and are in fact against that.

The results for this question largely confirm Lamb's (2012) results showing that his results are applicable at another New Zealand university. Only minor differences exist on most of the statements. Overall the results of both studies show that participants prefer that both print and ebooks are purchased and they are definitely not in favour of completely replacing print with ebooks.

Another question taken from Lamb's (2012) study asked participants to indicate which factors from a list would make ebooks more suitable for use in teaching and/or for research in their subject area. Ability to download was chosen by the most participants with $84.67 \%$ compared with $71 \%$ in Lamb's study. The importance of being able to download is already highlighted above and was relatively common in the comments section of the survey. Less restrictions on printing and copying was also a popular choice with $66.39 \%$ of participants choosing this option while $67 \%$ of participants chose it in Lamb's study. Greater breadth and depth of the collection was the third most popular choose with $53.02 \%$ at UC and $52 \%$ at Waikato. More current titles received $47.47 \%$ almost the same as the $48 \%$ in Lamb's (2012) study. These two factors show that for many users the quality of the collection affects their use of ebooks. Better research tools was almost as popular a choice with $46.82 \%$ and $47 \%$ in the previous study. The remaining four factors followed the same trend as Lamb's results receiving less than $40 \%$ indicating they are less significant factors for users. Lamb rightly notes that many of these factors are controlled by publishers and vendors. The role the library can play in this equation is to purchase ebooks where possible in ways that conform to these factors especially the most highly chosen factors. $10.28 \%$ of participants chose the Other option and left a comment. 13 of these comments merely reinforced existing options in the list of factors. A further 54 comments added new factors. The most significant categories of comments were to do with the importance of being able to search full-text, highlighting problems with the format, layout or interface of ebooks, or noting the importance of ebooks being easy to find. 


\section{What types of written material, if any, do users prefer in either ebook or print format?}

One question in the survey sort to determine what format, participants preferred different types of written material. The question was taken directly from Corlett-Rivera and Hackman's (2014) study and can be compared with their results. This question is also designed to help the UC Library make better decisions when decided whether to purchase particular books in print or ebook format. The results when compared with Corlett-Rivera and Hackman's (2014) results show remarkably similar trends.

Scholarly monographs were preferred in print by the largest group in both studies with $44.30 \%$ in this study and $41 \%$ in the previous study. For edited collections the results in both studies were also similar and showed a fairly even split between a preference for print and a preference for ebook with $34.33 \%$ and $31.84 \%$ respectively compared with $33 \%$ and $32 \%$ in the previous study. In both studies conference proceedings were obviously preferred in ebook format but this trend was even more pronounced in the UC study. The previous study found $41 \%$ in favour of conference proceedings in ebook format while print was preferred by just $18 \%$. In the UC study the figures were $57.43 \%$ and $13.04 \%$ respectively. This represents a margin of around $44 \%$ which is double the margin in the previous study. Ebooks were strongly preferred for general reference and specialized reference also in the previous study with margins of $25 \%$ and $22 \%$ percent respectively over the print preference. The UC study showed similar results with $46.86 \%$ and $43.89 \%$ ebook preference for general and specialised reference representing margins of around $25 \%$ and $17 \%$. Both studies showed strong preference for ebooks for citation manuals and style guides with a margin of $30 \%$ in the previous study and about $42 \%$ in the UC study, with a $58.22 \%$ preferring ebook format. Literature was the only other category that showed a strong preference for print with $55.35 \%$ in the UC study representing around a $35 \%$ margin which was significantly higher than the $18 \%$ margin in the previous study.

The No preference answers ranged from $16.64 \%$ for Literature through to $22.94 \%$ for general reference. The It depends answers ranged from $6.41 \%$ for Citation manuals and style guides through to $14.10 \%$ for edited collections. The previous study had a note asking those who chose it depends to leave a comment in the comments section at the end of the survey explaining why they chose it depends. The UC study neglected to ask participants to explain their it depends answers in the comment section which represents a serious limitation of this study. Any future study would do well to not make this same mistake as the it depends answers are a lot less useful without knowing the reason behind it. In the previous study participants chose it depends for a variety of reasons including convenience, that is whether or not they already planned to go to the library, what mood they participant was in, how urgently they require the information or what the end goal of their information searching was. It seems likely that the participants at UC would have had similar reasons for choosing it depends given the results showed very similar trends to the previous study for each type of written material. To sum up the UC study confirms the results of Corlett-Rivera and Hackman's (2014) study showing that only literature and scholarly monographs are preferred in print while the other categories are preferred in ebook format except edited collections which are relatively evenly split in terms of preference between print an ebook. 


\section{What degree of practical overlap, that is the degree of overlap there is between print collection availability and ebook collection availability, do users' believe there is?}

Two questions looked at participants' perception of the practical overlap, that is the extent to which titles are available in both print and ebook in the UC Library collection. Anderson and Pham (2013) found that at an Australian university that the practical overlap was just 30\% while previous studies (Link, 2012; Pomerantz, 2010; Price \& McDonald, 2008, as cited in Anderson \& Pham, 2013) found lower practical overlap percentages. The vast majority of users believed that the practical overlap was fewer than $60 \%$ while the $20 \%$ - $39 \%$ was the most popular choice with $42.60 \%$ percent of users choosing this option. The next most popular choose was the $0 \%-19 \%$ choose with $32.31 \%$. It would have perhaps been better to give participants a range of categories in $10 \%$ blocks rather than just five $20 \%$ blocks so as to pinpoint the perceived practical overlap with a little more accuracy or even ask participants to say exactly what percentage they believe it is. Never the less we can at least say that a significant number of users believe that it is in the $20 \%$ to $40 \%$ range which loosely fits with previous studies findings of actual practical overlap. In a future study it would be useful to test the actual practical overlap in the UC Library collection with users' perception to further to understand whether users have an accurate understanding of the practical overlap or not. Where users believe the practical overlap is significantly lower than it is, it would mean that the Library needs to do a better job of promoting its ebook collections. As it stands the results in this survey tentatively suggest that users' perception is probably not too far off the mark.

The other question relating to practical overlap sort to understand what format participants felt that books they want to read are usually available to them in; print, ebook or both. The question did not refer specifically to the UC Library's collections. Print and ebook was the most popular choice with $57.14 \%$. Interestingly this is higher than the perceived practical overlap percentages in the previous section where the largest group of participants believed it was in the $20 \%-39 \%$ range. This could be due to several factors. Participants may be getting the books they want to read from sources other than the Library such as on Amazon.com where the practical overlap may be higher. Also, the books they usually want to read are likely to be books published recently which are therefore more likely to be available as ebooks than much of the UC Libraries collection that would have been published before ebooks became widespread and may not yet have been digitised. Significantly, $28.93 \%$ of participants believed that the books they want to read are usually only available to them in print. It could be that in their subject not many books are published in ebook format or that they usually read older books. It could also be that they either are not finding ebooks that are available to them or that ebooks exist for the books they want to read but that they do not have access to them for some reason. It would be useful in a future study to probe this in more detail with qualitative questions to find out why the participants believe books are only available to them in print. 


\section{What factors, if any, affect users switching from print to ebook format?}

Sanford (2013) sort to test what factors, based on Migration Theory, affected users switching from print books to ebooks. A question in this survey asked participants a serious of questions based on the factors than Sanford had identified which were then compared with answers to a final question about how likely they were to increase their use of ebooks. The answers for participants who intended to increase their use of ebooks were compared with the overall sample to see whether or not each factor seemed to have a correlation with intention to increase ebook use. It was found that in each case those who intended to increase their use of ebooks had a significant difference in percentage agreement with each statement than the overall sample showing that the factors do seem to affect users' intention to increase use of ebooks. The bigger the difference in agreement percentage the more the factor would appear to correlate with intension to increase use. Furthermore, Chi-square tests of each factor compared with intention to increase use of ebooks showed that the answers for all factors had a statistically significant relationship.

Sanford (2014), who used a different methodology, found that level of satisfaction with print books and switching cost, that is how difficult it is to learn how to use ebooks, affected switching the most, in his longitudinal study of actual print and ebook use in a single class over three months. Sanford (2013) also found that the relative advantage of ebooks and personal innovativeness with information technology affected switching to a lesser extent. The UC study found that the relative advantage of ebooks had the most significant correlation with intention to increase ebook use, while satisfaction with print, personal innovativeness and subjective norm, that is the perception that pairs think they should increase use of ebooks, all showed a correlation to a lesser extent. The switching cost, or difficulty of learning how to use ebooks was the only factor that showed almost no correlation with intention to increase use which is in stark contrast to Sanford's (2013) results that showed it was one of the strongest factors. These results could prove useful for the UC Library in its marketing of ebooks to its users. In particular it is useful to know that despite users sometimes claiming they have difficulty learning how to access and use ebooks that this does not seem to be preventing users increasing their use of ebooks.

\section{Does age affect users' perception of or use of ebooks and, if so, how does it affect their perception of or use of ebooks?}

The participants' ages were fairly evenly split between all age group answers with $40-49$ being the smallest group with $18.79 \%$ and the largest group being the $30-39$ year olds with $28.76 \%$. The first Chi-square test result that found a P-value indicating that there was a significant relationship between age and the answers to a question was with regard to the percentage of practical overlap, explained above, between the ebook and print collections at UC. All of the different age groups showed quite different trends for their perceived practical overlap. There was no clear trend connecting answers to increasing age. The oldest group did have the highest percentage of answers in the $0 \%-19 \%$ answer but there, $30-39$ year old group had around $10 \%$ less in this answer compared to the youngest group, the $20-29$ year olds, with $20.25 \%$ and $31.69 \%$ respectively. Without further investigation it is hard to say what might be influencing the quite different trends within certain age groups for this question but age definitely does affect perception of practical overlap. 
Format preference for different types of written material also shows a significant relationship between age and preference for five out of the seven different types of written material. Only edited collections and general reference did not have a significant relationship with age. As with practical overlap, increasing age does not seem to precisely correspond with a preference for either print or ebook format. There is a clear trend, however, with the second youngest group, the $30-39$ year olds, always having the highest preference for ebooks relative to the other age groups, followed by the youngest group, the $20-29$ year olds. The $40-49$ year olds then had a lower preference for print and the 50+ group had the lowest preference for print. The one exception to this trend is for literature, where for some reason the 20-29 year olds had had the lowest preference for ebooks of any group beating even the $50+$ group by a margin of $7.51 \%$. We can say that those under 40 usually prefer ebooks more often than those 40 and older, as long as it is noted that the $30-39$ year olds have the highest rates of ebook preference.

Four out of the 11 ebook features which were ranked by participants in terms of their importance showed a significant relationship according to their P-values:

- Ability to download the whole e-book to computer or laptop for later use

- Ability to read on a mobile device (e.g., iPhone, iPad, Blackberry)

- Ability to annotate, bookmark or make notes

- Ability to search within the full-text of items

Each feature showed a different trend for the age groups. The ability to download was about $10 \%$ more valuable for the two youngest age groups compared to the two older age groups, $93.67 \%$, $93.64 \%, 84.21 \%$ and $84.11 \%$ respectively. This trend is remarkably clear and consistent; those 40 and older value being able to download ebooks less than those under 40 . The ability to read ebooks on a mobile device had some surprising results. The youngest group, who were expected to be the heaviest users of mobile devices, were ambivalent on this feature with approximately the same percentage unimportance as percentage importance with $36.71 \%$ and $35.55 \%$ respectively. In sharp contrast, the next youngest group placed the highest importance on this of any age group with $52.87 \%$, a margin of $30.46 \%$ over there unimportance value of just $22.41 \%$. The $40-49$ year olds were only slightly more likely to think it was important while the $50+$ group were a little more likely to rank it as unimportant. Clearly the 30-39 year olds are the key group for mobile device use with ebooks with around half of them believing it is an important feature.

Finally age was also found to have a significant relationship with six of the nine opinion statements about book formats:

- Ebooks are as good as print books

- The library should purchase book titles in both print and ebook format

- The library should purchase book titles in ebook format instead of print format

- If available, I would prefer to use ebooks as resources rather than print books for teaching or research

- Ebooks are suitable resources for my teaching and/or research

- Ebooks provided by the University of Canterbury Library are easy to find

The trend in answers was fairly clear cut in terms of percentage agreement. The youngest two age groups had similar percentages and these were usually around $5 \%$ to $15 \%$ higher than the older two age groups who also tended to have similar percentage agreement scores to each other. The only exception to this trend was the last opinion statement. In terms of how easy ebooks are to find at 
UC, the percentage agreement scores were closer together and the two middle age groups had the highest scores with $57.47 \%$ and $57.39 \%$, while the $20-29$ year olds had $52.20 \%$ and the $50+$ group has the lowest percentage agreement with $48.39 \%$. In general these results, with the exception of the last statement, indicate that those under 40 have a more positive view of ebooks than those 40 or older.

\section{Does gender affect users' perception of or use of ebooks and, if so, how does it affect their perception of or use of ebooks?}

The study participants were split between male and female relatively evenly but with more males at $52.78 \%$ compared to $46.24 \%$ females. Additionally, six participants chose l'd rather not say. Gender showed a statistically significant relationship with perception of the percentage of practical overlap between the UC print collection and ebook availability. Almost half, $49.23 \%$, of all females believed the practical overlap was $20 \%$ - 39\% which was higher than the whole sample with $42.60 \%$. In contrast the males had a higher percentage for the $0 \%-19 \%$ answer with $37.85 \%$ compared to only $32.31 \%$ for the whole sample and just $25.38 \%$ for females. Only $37.15 \%$ of males chose $20 \%-39 \%$ practical overlap which is about the same percentage that chose $0 \%-19 \%$. When males and females are compared we can say that females are much more likely to believe there is a higher practical overlap than males.

Unlike age, only one type of written material, namely literature, had a significant relationship with gender. Although print was the preferred book format for literature for both males and females, females show a comparatively higher preference for print while males show a comparatively higher preference for ebooks. Females chose print with a margin of difference of $45 \%$ over ebooks while the margin for males was only $28.04 \%, 16.96 \%$ lower than females.

Five of the 11 ebook features showed a significant relationship with gender:

- Ability to find e-books in search engines (e.g., Google, Yahoo)

- Ability to download the book chapters or portions of the e-book to computer or laptop for later use

- Ability to read on a mobile device (e.g., iPhone, iPad, Blackberry)

- Ability to annotate, bookmark or make notes

- Ability to link to a particular chapter

All but the second feature above had a higher importance percentage for females compared with males, while the second feature showed the opposite trend with a slightly higher importance percentage for males. The margin of difference for each feature is as follows: $0.17 \%, 6.25 \%, 2.04 \%$, $11.13 \%$ and $9.23 \%$. The $0.17 \%$ and $2.04 \%$ are not large margins and for these features the significant differences are between those who gave a higher percentage of Somewhat important compared with Very important. For the first feature females chose somewhat important at a higher rate while males chose very important more often but when the scores for both are added together the overall importance percentage for males and females is almost the same. For the third feature above the difference is mainly in the neutral answers and the unimportance percentage. Females were $10.36 \%$ more likely to choose the neutral option than males while males had an $8.59 \%$ higher unimportance percentage than females. Generally we can say that there is a small trend for females to rank some ebook features as more important than males although is trend is by no means universal even amongst the features that had a statistically significant relationship with gender. 
Only one of the nine opinion statements had a significant relationship with gender: Ebooks provided by the University of Canterbury Library are easy to find. Females had a margin of difference of $16.22 \%$ compared with males in terms of agreement with this statement. $62.63 \%$ of females agreed with the statement while only $46.42 \%$ of males did. Males however had over $10 \%$ higher neutral response to this statement. Females it would seem find the ebooks at in the UC Library significantly easier to find than males do.

Posigha (2012) found that there was a statistically significant relationship between gender and use of ebooks with men using ebooks more often than women. This confirmed a previous study with the same result (Monopoli et al., 2002, as cited in Posigha, 2012). This study did not find a significant difference between males and females in terms of actual use of ebooks but there is some difference in terms of opinion and particularly males' higher preference for literature compared to females hints at higher use. However, in other respects females indicated a more positive view of ebooks in terms of a higher perceived practical overlap, placing higher importance on certain ebook features and finding ebooks easier to find.

\section{Does academic status, that is if they are an academic or a $P h D$ student, affect users' perception of or use of ebooks and, if so, how does it affect their perception of or use of ebooks?}

Academic status refers to whether or not participants were PhD students or academic staff. Academic staff represented $45.25 \%$ of participants while PhD students represented $47.05 \%$. A further $7.70 \%$, or 47 people, chose the other option. In retrospect it would have been helpful to allow users to enter a reason for choosing other. It may be that they were general staff or non-PhD students wrongly sent the email survey invite or they may have been both a PhD student and an Academic staff member. No participants mentioned this question in the comments section at the end of the survey.

Unlike the other variable groups, status showed a statistically significant relationship with the questions about in what format books the participants want to read are in. If we add the percentages for Print and ebook to both the percentage for Print only and Ebook only we can see that academics were $10.92 \%$ more likely to perceive books they wanted to read to be available in print than PhD students while PhD students were 3.77\% more likely to believe that books they wanted to read were available as ebooks than academics. It is tempting to think this might be due to the likely younger age of PhD students compared with academics but this does not seem to have affected the answers as the age variable showed no statistically significant relationship with this question. It presumable points to a difference in how academics and PhD students are accessing or using books. It could be for example that PhD students are more likely to be reading written material that is more widely preferred in ebook format such as conference proceedings while academics might be more likely to be reading literature or scholarly monographs that are more commonly preferred in print. A future study would do well to follow up on this trend and conduct a detailed analysis of what factors might lead to this trend.

Academic status showed a statistically significant relationship with the practical overlap question as age and gender had also. In fact college was the only variable that did not show a significant relationship with perceived practical overlap. The trend for practical overlap and status was similar to the trend for what format books they want to read are usually available in. Academics showed a larger percentage of $0 \%-19 \%$ practical overlap answers than the whole sample with $37.85 \%$ 
whereas PhD students had a relatively higher percentage in the $40 \%$ - 59\%, with $23.64 \%$, which was $10.09 \%$ higher than academics with only $13.55 \%$. In other words PhD students tended to think that there were more ebooks while academics tended to think there were fewer as a general trend.

Status also had a statistically significant relationship with format preference for particular types of written material according to the Chi-square tests. Four types of written material had a significant relationship in terms of format preference: scholarly monographs, general reference, specialized reference and citation manuals and style guides. If we look at the first type of written material, scholarly monographs we can see the difference of preference between academics and PhD students. Academics chose print as their preferred choose with a margin of $26.10 \%$ over ebooks whereas for PhD students the margin was only $11.93 \%$. The other three types of written material were all preferred in ebook format but academics tended to prefer ebooks by a lower margin than $\mathrm{PhD}$ students, although the difference was only $1.31 \%$ for citation manuals and style guides but the academics had a much higher percentage of no preference than the PhD students.

Five out of the 11 ebook features had a statistically significant relationship with academic status according to the Chi-square testing:

- Ability to find e-books in search engines (e.g., Google, Yahoo)

- Ability to read on a dedicated e-book reader, (e.g., Kindle, Sony Reader)

- Ability to search within the full-text of items

- Ability to link to a particular chapter

- Availability of a print copy of the same title from the Library

If we look at the importance percentage for each feature we can see that in all five cases the PhD students ranked the features as more important than the academics. The margin of difference for importance was $10.08 \%, 7.41 \%, 7.28 \%, 13.06 \%$ and $12.11 \%$ respectively, for the above five features; a range of $7.28 \%$ to $13.06 \%$ higher importance percentage for PhD students. This result seems to reinforce the general trend that PhD students use ebooks more often and have a more favourable opinion of ebooks and in particular the above five ebook features.

Of the nine opinion statements regarding book format four showed a significant relationship with the status of the participants:

- Ebooks are as good as print books

- The library should purchase book titles in both print and ebook format

- If available, I would prefer to use ebooks as resources rather than print books for teaching or research

- Ebooks are suitable resources for my teaching and/or research

Similar to the ebook features, the above four statements had a higher agreement percentage in all cases for PhD students compared with academics. The margins between the two status groups for these statements are as follows: $12.18 \%, 16.35 \%, 4.48 \%$ and $10.84 \%$ respectively. Again these results reinforce that $\mathrm{PhD}$ students, at least to a certain extent, have a more favourable opinion of ebooks than academic staff. The second statement does not necessarily mean a more favourable opinion of ebooks but taken in the context of the other three points it seems likely that a higher agreement percentage with regard to purchasing books in both print and ebook format probably indicates a higher acceptance of ebooks. 


\section{Does academic discipline affect users' perception of or use of ebooks and, if so, how does it affect their perception of or use of ebooks?}

In this study academic discipline was measured in terms of what college the respondents were mainly affiliated with. The results showed that the Colleges of Business and Law and Education were underrepresented in the survey while the Colleges of Engineering and Arts were over represented. The College of Science was about equal to the total population percentage. Together the colleges of Science and Engineering made up over half the sample population with $56.30 \%$. The first statistically significant relationship produced by Chi-square tests was for the question on use of an ebook provided by the UC Library. College was the only variable to have a statistically significant relationship with this question's answers. When the results were grouped together into those who had used an ebook at least once and those who had never used an ebook three colleges answers closely resembled the whole sample but the College or Arts and the College of Business and Law both showed quite different trends and opposite trends from each other. Arts participants were $8.12 \%$ more likely to have used an ebook from the UC Library than the sample as a whole while Business and Law participants were exactly $8.00 \%$ less likely to have used an ebook from the Library. This is a significant result and one the Library should take note of when purchasing ebooks for those two Colleges or when considering promoting ebooks to those two Colleges. What is not known here is would the same results have occurred if the question was about print books or books in general. It seems likely that the College of Arts is probably a bigger user of books in general while the College of Business and Law is perhaps a lower user of books given the nature of the subjects taught in those two colleges. A future study would do well to ask a question regarding book use in general in order to check if this result is specific to ebooks, meaning for example that Arts people use ebooks more often than others, or whether it is just that they use any kind of book more often.

Interestingly, the College variable did not have a statistically significant relationship with perception of practical overlap unlike all three other variables. College did have a significant relationship with the book format preference for four of the seven types of written material: Conference proceedings, specialized reference, citations manuals and style guides and literature. When we look at the margin between the percentage preference for the preferred format type and the less preferred type for each question no obvious pattern emerges. What is obvious, however, is that for each type of written material the answers by college differ significantly. For each type of written materials preferred format type percentage the percentage of preference has a margin of between $22.56 \%$ and $37.22 \%$ between the college with the highest preference percentage and the college with the lowest percentage preference. For example, for conference proceedings ebook is the preferred format for all colleges but the preference margin over ebooks is only $30.77 \%$ for Arts participants while it is 53.33\% for Engineering participants. No college consistently has the highest margin of format preference or the lowest making it hard to see any discernible pattern without further investigation. We can say for sure though that at least for these four types of written material that which college a participant is affiliated has a statistically significant relationship with their format preference with quite wide margins of differences between colleges.

The college variable showed the least statistically significant relationships with the importance of particular ebook features of any variable. Only one feature, the ability to find ebooks 
in the Library catalogue, showed a significant relationship with college. When the importance rating percentage for each college is examined we can see that the scores for each college are only slightly different from each other. The answers are only around $1 \%$ or $2 \%$ on either side of the percentage for the whole sample and the margin between the lowest college, Education, and the highest college, Science is only $3.59 \%$. We can conclude then the college affiliation plays only a very small part in the perceived importance of this one particular ebook feature.

Only two of the opinion statements showed a significant relationship in terms of agreement with the statement:

- Ebooks are as good as print books

- If available, I would prefer to use ebooks as resources rather than print books for teaching or research

For the first statement the margin between the college with the lowest percentage agreement, Business and Law, and the college with the highest, Science, was $8.95 \%$. For the second statement the margin was $15.66 \%$ between Science again with the highest percentage agreement and this time Education with the lowest. Science and Engineering had the highest and second highest agreement with both statements, although for the second statement Business and Law had almost the same percentage agreement as Engineering. From this result we can confer that Science and Engineering are at least a little more favourably disposed to ebooks than the other three colleges and then opinion amongst the five colleges is somewhat varied.

\section{Qualitative Comments}

167 participants left comments at the end of the survey although many of the comments were actually multiple comments resulting in their categorisation into 307 separate comments. $20.85 \%$ of the comments were positive about ebooks while almost twice as many were negative about ebooks with $38.76 \%$. A further $37.79 \%$ of comments were general comments about ebooks and a small number of miscellaneous comments were also received. Ease of access, the ability to search full-text and the portability of ebooks stand out as the most important themes of the positive comments. The most often cited negative comments regarding ebooks were that they simpler prefer print without stating why, highlighting problems with the layout, format, interface or software associated with ebooks, that they don't like reading screens or problems to do with limited loan periods. With regard to reading screens some participants felt they already spent too much time in front of a screen or that it was hard on their eyes. Several comments noted that it is harder to take in information on a screen than with print.

The most popular general comments highlighted the importance of being able to print and copy without restrictions, being able to download ebooks and being able to have multi-user or unlimited-user access to ebook titles. Additionally, many comments highlighted that ebooks are good for short use while print is better for longer use or reading a whole book. A related important category highlighted that book format preference depends on use or type of written material. Generally the comments reinforce that there are often too many restrictions on ebooks that make them less desirable to use. The comments also reinforce that many users would like to have access to both print and ebooks. Some users are also still very much in favour of print over ebooks. Ebook features that make them easier to use like being able to search full-text and being able to download 
them and print without restrictions are shown to be important factors for ebook use also. The comments largely backup the results of the rest of the study.

\section{Conclusion}

The results of the study clearly show that most users are aware of the UC Library ebook collection and most have used an ebook at least once. Attitudes towards and use of ebooks is varied amongst users and this should be noted by the Library management. Interestingly ebook readers and mobile devices were not a significant factor in ebook use at UC unlike in some previous studies were they were found to be important. However, the results of previous studies were largely confirmed by the results of this study with only a few differences observed, backing up the validity of those results in diverse academic contexts. The Library's search functionality is highly valued for finding ebooks, however, only about half of the participants found ebooks provided by the University of Canterbury Library easy to find meaning that some work is needed to make ebooks more accessible or that more marketing is needed.

Ability to download is highly valued by users at UC which was reinforced by many of the comments at the end of the survey. Similarly full-text search was also an ebook feature considered to be important by users. The Library needs to make sure that it is purchasing ebooks with these two features where possible to meet the needs of its users. The study also indicated that participants use ebooks and print books for different purposes. Ebooks are preferred for quick use while print is often preferred for concentrated reading. A common theme in the study is that the majority of users would like to see both ebooks and print books available at the UC library. Overall the results of this study and Lamb's (2012) study show that users prefer that both print and ebooks are purchased and they are definitely not in favour of completely replacing print with ebooks.

Fewer restrictions on printing and copying was a popular theme in the study. In the comments section some users believed these restrictions were a problem at UC. Greater breadth and depth of the collection was also highlighted as being necessary for greater ebook adoption. For many users the quality of the collection affects their use of ebooks and it is for some lacking at UC. The study clearly indicates which types of written material are preferred in print and which are preferred in ebook giving a clear guideline to the Library on what format it should choose to purchase certain types of books in. It is worth noting however, that ebook was the preferred format for four out of the seven types of written material indicating that ebooks have been largely accepted for some types of books. The relative advantages of ebooks, such as their portability and full-text search, had the most significant correlation with intention to increase ebook use in the study. The advantages of ebooks need to be pushed more strongly by the Library is it wants to increase user uptake of ebooks.

The study clearly shows that age does affect users' attitudes towards and use of ebooks in some cases. Users under 40 usually prefer ebooks more often than those 40 and older, although users in the 30-39 year old group have the highest rates of ebook preference. Not surprisingly, in general those under 40 have a more positive view of ebooks than those 40 or older. Gender was also found to affect users' perception of and use of ebooks. The study did not find a significant difference between males and females in terms of actual use of ebooks but there is some difference in terms of opinion and particularly males' higher preference for literature compared to females hints at higher use. However, in other respects females indicated a more positive view of ebooks in terms of a 
higher perceived practical overlap, placing higher importance on certain ebook features and finding ebooks easier to find.

Academic status was also found to have some effect on users' opinions of and use of ebooks. Academics were more likely to perceive books they wanted to read to be available in print than PhD students while PhD students were more likely to believe that books they wanted to read were available as ebooks than academics. This could be due to the likely younger age of PhD students compared with academics but this does not seem to have affected the answers as the age variable showed no statistically significant relationship with this question. It presumable points to a difference in how academics and PhD students are accessing or using books. The results show that in general PhD students use ebooks more often and have a more favourable opinion of ebooks than academics

College affiliation too has an effect on ebook use and opinions of ebooks. Arts users were more likely to have used an ebook from the UC Library than the other colleges while Business and Law users were less likely to have. This is a significant result and one the Library should take note of when purchasing ebooks for those two Colleges or when considering promoting ebooks to those two Colleges. However, what is not known here is would the same results have occurred if the question was about print books or books in general. It seems likely that the College of Arts is probably a bigger user of books in general while the College of Business and Law is perhaps a lower user of books given the nature of the subjects taught in those two colleges. A future study would do well to ask a question regarding book use in general in order to check if this result is specific to ebooks, meaning for example that Arts people use ebooks more often than others, or whether it is just that they use any kind of book more often. The study also showed that the Colleges of Science and Engineering are a little more favourably disposed to ebooks than the other three colleges.

Some of the factors that put users of using ebooks include problems with the layout, format, interface or software associated with ebooks. Users also indicated that they do not like reading screens and that there are problems to do with limited loan periods. With regard to reading screens some participants felt they already spent too much time in front of a screen already. A common perception is that it is harder to take in information on screens than with print.

Generally user comments reinforce that there are often too many restrictions on ebooks that make them less desirable to use. The comments also reinforce that many users would like to have access to both print and ebooks. Some users are also still very much in favour of print over ebooks. Ebook features that make them easier to use like being able to search full-text and being able to download them and print without restrictions are shown to be important factors for ebook use also.

\section{Recommendations}

- The Library should increase marketing to target the $8 \%$ of users who are not aware of Library's ebook collection

- Books should be ordered in print and ebook format whenever possible and the Library should maintain relevant print and ebook collections

- The Library should purchase ebooks with the fewest possible restrictions wherever possible or purchase print instead if heavily restricted ebooks are the only option 
- The Library should take note of what types of written material are preferred in what format and use this information in deciding between print and ebook formats when not purchasing both formats.

- Library promotion of ebooks should focus on the relative advantage of ebooks as this had the most significant correlation with intention to increase ebook use

\section{Limitations}

The study was limited to only academics and PhD students meaning that undergraduate students' and other postgraduate students' attitudes towards and use of ebooks were not represented in the study. Another limitation was that the other option for several questions lacked a comments box to explain the answer meaning that a certain percentage of answers were less useful than they could have been. One question had it depends as one of the choices and the previous study that this question was taken from asked users to clarify this answer in the comments section. This study neglected to ask participants to explain their it depends answer which was a limitation to the study. Additionally, there was a minor mistake in one question in that Library Search, Waikato's branding of the Summon discovery layer tool, should have been rewritten as MultiSearch, UC's branding for Summon. The questions around practical overlap were limited in scope as the actual practical overlap was not calculated.

\section{Future Research}

As noted above an interesting future study would be to examine the actual practical overlap at UC and then to compare this result with the perceived practical overlap to ascertain how accurate users perceptions of the practical overlap are and how this might affect the attitudes towards and use of ebooks. It would be useful in a future study to examine how ebook reader ownership in New Zealand compares to ownership overseas and particularly in the United States given that it was not found to be important factor in ebook use at UC but was found to be important in some previous studies. A significant number of users believe that the books they want to read are usually only available in print. It would be useful in a future study to probe this in more detail with qualitative questions to find out why the participants believe books are only available to them in print. There was a discernible trend for PhD students to be more favourably disposed to ebooks than academics and a future study would do well to follow up on this trend and conduct a detailed analysis of what factors might lead to it. There was much variation in terms of preference for certain types of written material in either ebook or print format amongst the different colleges but it was hard to see any discernible pattern without further investigation. College of Arts users were observed to used ebooks more often than other colleges while College of Business and Law users showed the opposite trend. A future study could ask a question regarding book use in general in order to check if this result is specific to ebooks, meaning for example that Arts people use ebooks more often than others, or whether it is just that they use any kind of book more often. 


\section{Publication Venues}

The annual conference of the Library and Information Association of New Zealand Aotearoa (LIANZA) provides one possible venue for communicating the results of this study. Additionally, the research may be able to be published in a local journal such as the New Zealand Library \& Information Management Journal, published by LIANZA, or in an appropriate international journal such as the Journal of Academic Librarianship or Library Hi Tech. 


\section{References}

Borchert, M., Hunter, A., McDonald, D., \& Tittel, C. (2009). A study on student and staff awareness, acceptance and usage of e-books at two Queensland universities. Paper presented the Information Online 2009, 14th ALIA Exhibition and Conference, Australia. Retrieved from http://eprints.usq.edu.au/4876/

Corlett-Rivera, K., \& Hackman, T. (2014). E-book use and attitudes in the humanities, social sciences, and education. portal: Libraries and the Academy, 14(2), 255-286. doi:10.1353/pla.2014.0008

Lamb, A. (2012). An investigation of academics' perception, uptake and use of ebooks at the University of Waikato. Unpublished MIS research project, Victoria University of Wellington, Wellington, New Zealand.

Leedy, P. D., \& Ormrod, J. E. (2013). Practical research: Planning and design (10th ed.). Boston, MA: Pearson.

Link, F. E. (2012). Are we there yet? An analysis of e-book equivalent coverage in highly-circulated titles at the College of New Jersey Library. Collection Building, 31(4), 132-135. doi:10.1108/01604951211274034

Posigha, B. E. (2012). The use and future of electronic books in academic institutions in Nigeria. The Electronic Library, 30(6), 796-808. doi:10.1108/02640471211282118

Sanford, C. (2013). An artifact switching model for user acceptance of eBooks. Journal of Organizational and End User Computing, 25(2), 19-40. doi:10.4018/joeuc.2013040102

Savova, M., \& Garsia, M. (2012). McGill Library makes e-books portable: E-reader loan service in a Canadian academic library. portal: Libraries and the Academy, 12(2), 205-222. doi:10.1353/pla.2012.0019

Slater, R. (2010). Why aren't e-books gaining more ground in academic libraries? E-book use and perceptions: A review of published literature and research. Journal of Web Librarianship, 4(4), 305-331. doi:10.1080/19322909.2010.525419

Smyth, S., \& Carlin, A. (2012). Use and perception of ebooks in the University of Ulster: A case study. New Review of Academic Librarianship, 18(2), 176. doi:10.1080/13614533.2012.719851

University of Canterbury. (n.d). Types of qualifications. Retrieved from http://www.canterbury.ac.nz/courses/quals types.shtml

Vassiliou, M., \& Rowley, J. (2008). Progressing the definition of "e-book". Library Hi Tech, 26(3), 355368. doi:10.1108/07378830810903292

Vasileiou, M., Rowley, J., \& Hartley, R. (2012). Perspectives on the future of e-books in libraries in universities. Journal of Librarianship and Information Science, 44(4), 217-226.

doi:10.1177/0961000611434759 
Vaughan, L. (2001). Statistical methods for the information professional: A practical, painless approach to understanding, using, and interpreting statistics. Medford, NJ: Information Today.

Victoria University of Wellington. (n.d.). Human Ethics Guidelines. Retrieved from http://www.victoria.ac.nz/documents/policy/research-policy/appendix-a-human-ethicscommittee-guidelines.pdf

Walters, W. H. (2013). E-books in academic libraries: Challenges for acquisition and collection management. portal: Libraries and the Academy, 13(2), 187-211. doi:10.1353/pla.2013.0012

Widdersheim, M. M. (2014, Summer). E-Lending and Libraries. Progressive Librarian, (42), 95114. Retrieved from EBSCOhost database. 


\section{Appendices}

Appendix 1: Frequency of Use of Library Ebooks by Collage Full Results

\begin{tabular}{|c|c|c|c|c|c|c|c|c|}
\hline \multirow[b]{3}{*}{ Group } & \multicolumn{8}{|c|}{ Answer } \\
\hline & \multicolumn{2}{|c|}{ Often } & \multicolumn{2}{|c|}{$\begin{array}{l}\text { A couple of } \\
\text { times }\end{array}$} & \multicolumn{2}{|c|}{ Once } & \multicolumn{2}{|c|}{ Never } \\
\hline & Freq. & $\%$ & Freq. & $\%$ & Freq. & $\%$ & Freq. & $\%$ \\
\hline Whole sample & 155 & $27.58 \%$ & 282 & $50.18 \%$ & 46 & $8.19 \%$ & 79 & $14.06 \%$ \\
\hline Arts & 45 & $44.55 \%$ & 44 & $43.56 \%$ & 6 & $5.94 \%$ & 6 & $5.94 \%$ \\
\hline $\begin{array}{c}\text { Business \& } \\
\text { Law }\end{array}$ & 15 & $22.06 \%$ & 31 & $45.59 \%$ & 7 & $10.29 \%$ & 15 & $22.06 \%$ \\
\hline Education & 24 & $30.77 \%$ & 39 & $50.00 \%$ & 3 & $3.85 \%$ & 12 & $15.38 \%$ \\
\hline Engineering & 32 & $21.05 \%$ & 83 & $54.61 \%$ & 15 & $9.87 \%$ & 22 & $14.47 \%$ \\
\hline Science & 36 & $22.93 \%$ & 84 & $53.50 \%$ & 15 & $9.55 \%$ & 22 & $14.01 \%$ \\
\hline
\end{tabular}

\section{Appendix 2. Statistically Significant Format Preferences for Different Types of Book by Age Group}

\begin{tabular}{|c|c|c|c|c|c|c|c|c|c|c|c|}
\hline \multirow[b]{2}{*}{$\begin{array}{l}\text { Book } \\
\text { Type }\end{array}$} & \multirow[b]{2}{*}{ Age } & \multicolumn{2}{|c|}{ I prefer print } & \multicolumn{2}{|c|}{ No preference } & \multicolumn{2}{|c|}{ I prefer ebooks } & \multicolumn{2}{|c|}{ It depends } & \multicolumn{2}{|c|}{ Grand Total } \\
\hline & & Freq. & $\%$ & Freq. & $\%$ & Freq. & $\%$ & Freq. & $\%$ & Freq. & $\%$ \\
\hline \multirow{5}{*}{ 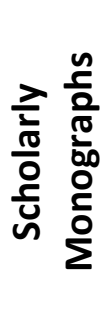 } & $20-29$ & 65 & $40.88 \%$ & 34 & $21.38 \%$ & 44 & $27.67 \%$ & 16 & $10.06 \%$ & 159 & $100.00 \%$ \\
\hline & $30-39$ & 62 & $35.63 \%$ & 31 & $17.82 \%$ & 60 & $34.48 \%$ & 21 & $12.07 \%$ & 174 & $100.00 \%$ \\
\hline & $40-49$ & 57 & $49.57 \%$ & 21 & $18.26 \%$ & 26 & $22.61 \%$ & 11 & $9.57 \%$ & 115 & $100.00 \%$ \\
\hline & $50+$ & 83 & $54.61 \%$ & 30 & $19.74 \%$ & 22 & $14.47 \%$ & 17 & $11.18 \%$ & 152 & $100.00 \%$ \\
\hline & $\begin{array}{l}\text { Grand } \\
\text { Total }\end{array}$ & 268 & $44.30 \%$ & 116 & $19.17 \%$ & 154 & $25.45 \%$ & 67 & $11.07 \%$ & 605 & $100.00 \%$ \\
\hline \multirow{5}{*}{ 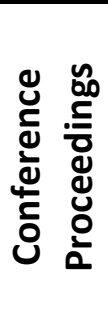 } & $20-29$ & 22 & $13.84 \%$ & 34 & $21.38 \%$ & 91 & $57.23 \%$ & 12 & $7.55 \%$ & 159 & $100.00 \%$ \\
\hline & $30-39$ & 19 & $10.98 \%$ & 24 & $13.87 \%$ & 119 & $68.79 \%$ & 11 & $6.36 \%$ & 173 & $100.00 \%$ \\
\hline & $40-49$ & 16 & $13.91 \%$ & 28 & $24.35 \%$ & 61 & $53.04 \%$ & 10 & $8.70 \%$ & 115 & $100.00 \%$ \\
\hline & $50+$ & 22 & $14.29 \%$ & 50 & $32.47 \%$ & 74 & $48.05 \%$ & 8 & $5.19 \%$ & 154 & $100.00 \%$ \\
\hline & $\begin{array}{l}\text { Grand } \\
\text { Total }\end{array}$ & 79 & $13.04 \%$ & 137 & $22.61 \%$ & 348 & $57.43 \%$ & 42 & $6.93 \%$ & 606 & $100.00 \%$ \\
\hline \multirow{4}{*}{ 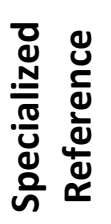 } & $20-29$ & 43 & $27.04 \%$ & 28 & $17.61 \%$ & 69 & $43.40 \%$ & 19 & $11.95 \%$ & 159 & $100.00 \%$ \\
\hline & $30-39$ & 39 & $22.29 \%$ & 22 & $12.57 \%$ & 95 & $54.29 \%$ & 19 & $10.86 \%$ & 175 & $100.00 \%$ \\
\hline & $40-49$ & 31 & $26.96 \%$ & 26 & $22.61 \%$ & 45 & $39.13 \%$ & 13 & $11.30 \%$ & 115 & $100.00 \%$ \\
\hline & $50+$ & 48 & $31.58 \%$ & 37 & $24.34 \%$ & 55 & $36.18 \%$ & 12 & $7.89 \%$ & 152 & $100.00 \%$ \\
\hline
\end{tabular}




\begin{tabular}{|c|c|c|c|c|c|c|c|c|c|c|c|}
\hline & $\begin{array}{l}\text { Grand } \\
\text { Total }\end{array}$ & 162 & $26.73 \%$ & 113 & $18.65 \%$ & 266 & $43.89 \%$ & 65 & $10.73 \%$ & 606 & $100.00 \%$ \\
\hline \multirow{5}{*}{ 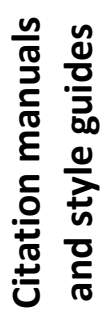 } & $20-29$ & 30 & $18.87 \%$ & 31 & $19.50 \%$ & 90 & $56.60 \%$ & 8 & $5.03 \%$ & 159 & $100.00 \%$ \\
\hline & $30-39$ & 21 & $12.00 \%$ & 16 & $9.14 \%$ & 127 & $72.57 \%$ & 11 & $6.29 \%$ & 175 & $100.00 \%$ \\
\hline & $40-49$ & 19 & $16.67 \%$ & 24 & $21.05 \%$ & 61 & $53.51 \%$ & 10 & $8.77 \%$ & 114 & $100.00 \%$ \\
\hline & $50+$ & 25 & $16.13 \%$ & 46 & $29.68 \%$ & 74 & $47.74 \%$ & 10 & $6.45 \%$ & 155 & $100.00 \%$ \\
\hline & $\begin{array}{l}\text { Grand } \\
\text { Total }\end{array}$ & 98 & $16.12 \%$ & 117 & $19.24 \%$ & 354 & $58.22 \%$ & 39 & $6.41 \%$ & 608 & $100.00 \%$ \\
\hline \multirow{5}{*}{ 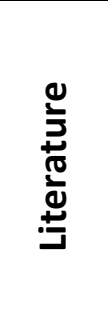 } & $20-29$ & 99 & $62.26 \%$ & 25 & $15.72 \%$ & 24 & $15.09 \%$ & 11 & $6.92 \%$ & 159 & $100.00 \%$ \\
\hline & $30-39$ & 90 & $51.72 \%$ & 19 & $10.92 \%$ & 51 & $29.31 \%$ & 14 & $8.05 \%$ & 174 & $100.00 \%$ \\
\hline & $40-49$ & 61 & $53.04 \%$ & 22 & $19.13 \%$ & 22 & $19.13 \%$ & 10 & $8.70 \%$ & 115 & $100.00 \%$ \\
\hline & $50+$ & 82 & $53.25 \%$ & 35 & $22.73 \%$ & 21 & $13.64 \%$ & 16 & $10.39 \%$ & 154 & $100.00 \%$ \\
\hline & $\begin{array}{l}\text { Grand } \\
\text { Total }\end{array}$ & 336 & $55.35 \%$ & 101 & $16.64 \%$ & 119 & $19.60 \%$ & 51 & $8.40 \%$ & 607 & $100.00 \%$ \\
\hline
\end{tabular}

\section{Appendix 3. Statistically Significant Format Preferences for Different Types of Book by Gender Group}

\begin{tabular}{|c|c|c|c|c|c|c|c|c|c|c|c|}
\cline { 2 - 13 } \multicolumn{2}{c|}{} & \multicolumn{2}{c|}{ I prefer print } & \multicolumn{2}{c|}{ No preference } & \multicolumn{2}{c|}{$\begin{array}{l}\text { I prefer } \\
\text { ebooks }\end{array}$} & \multicolumn{2}{c|}{ It depends } & \multicolumn{2}{c|}{ Grand Total } \\
\hline $\begin{array}{c}\text { Book } \\
\text { Type }\end{array}$ & Gender & Freq. & $\%$ & Freq. & $\%$ & Freq. & $\%$ & Freq. & $\%$ & Freq. & $\%$ \\
\hline \multirow{3}{*}{ Literature } & Female & 173 & $61.79 \%$ & 36 & $12.86 \%$ & 47 & $16.79 \%$ & 24 & $8.57 \%$ & 280 & $100.00 \%$ \\
\cline { 2 - 13 } & Male & 161 & $50.16 \%$ & 63 & $19.63 \%$ & 71 & $22.12 \%$ & 26 & $8.10 \%$ & 321 & $100.00 \%$ \\
\cline { 2 - 12 } & $\begin{array}{c}\text { Grand } \\
\text { Total }\end{array}$ & 336 & $55.35 \%$ & 101 & $16.64 \%$ & 119 & $19.60 \%$ & 51 & $8.40 \%$ & 607 & $100.00 \%$ \\
\hline
\end{tabular}

\section{Appendix 4. Statistically Significant Format Preferences for Different Types of Book by Status Group}

\begin{tabular}{|c|c|c|c|c|c|c|c|c|c|c|c|}
\hline \multirow[b]{2}{*}{$\begin{array}{l}\text { Book } \\
\text { Type }\end{array}$} & \multirow[b]{2}{*}{ Status } & \multicolumn{2}{|c|}{ I prefer print } & \multicolumn{2}{|c|}{ No preference } & \multicolumn{2}{|c|}{$\begin{array}{l}\text { I prefer } \\
\text { ebooks }\end{array}$} & \multicolumn{2}{|c|}{ It depends } & \multicolumn{2}{|c|}{ Grand Total } \\
\hline & & Freq. & $\%$ & Freq. & $\%$ & Freq. & $\%$ & Freq. & $\%$ & Freq. & $\%$ \\
\hline \multirow{3}{*}{ 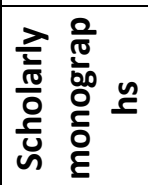 } & Academic & 132 & $48.53 \%$ & 48 & $17.65 \%$ & 61 & $22.43 \%$ & 31 & $11.40 \%$ & 272 & $100.00 \%$ \\
\hline & PhD & 119 & $41.75 \%$ & 52 & $18.25 \%$ & 85 & $29.82 \%$ & 29 & $10.18 \%$ & 285 & $100.00 \%$ \\
\hline & Other & 15 & $32.61 \%$ & 16 & $34.78 \%$ & 8 & $17.39 \%$ & 7 & $15.22 \%$ & 46 & $100.00 \%$ \\
\hline
\end{tabular}




\begin{tabular}{|c|c|c|c|c|c|c|c|c|c|c|c|}
\hline & $\begin{array}{l}\text { Grand } \\
\text { Total }\end{array}$ & 266 & $44.11 \%$ & 116 & $19.24 \%$ & 154 & $25.54 \%$ & 67 & $11.11 \%$ & 603 & $100.00 \%$ \\
\hline \multirow{4}{*}{ 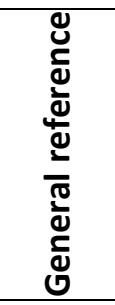 } & Academic & 57 & $20.96 \%$ & 71 & $26.10 \%$ & 118 & $43.38 \%$ & 26 & $9.56 \%$ & 272 & $100.00 \%$ \\
\hline & PhD & 65 & $22.73 \%$ & 53 & $18.53 \%$ & 151 & $52.80 \%$ & 17 & $5.94 \%$ & 286 & $100.00 \%$ \\
\hline & Other & 11 & $23.91 \%$ & 14 & $30.43 \%$ & 15 & $32.61 \%$ & 6 & $13.04 \%$ & 46 & $100.00 \%$ \\
\hline & $\begin{array}{l}\text { Grand } \\
\text { Total }\end{array}$ & 133 & $22.02 \%$ & 138 & $22.85 \%$ & 284 & $47.02 \%$ & 49 & $8.11 \%$ & 604 & $100.00 \%$ \\
\hline \multirow{4}{*}{ 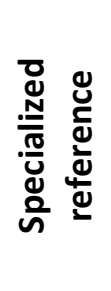 } & Academic & 72 & $26.47 \%$ & 55 & $20.22 \%$ & 112 & $41.18 \%$ & 33 & $12.13 \%$ & 272 & $100.00 \%$ \\
\hline & PhD & 78 & $27.27 \%$ & 42 & $14.69 \%$ & 140 & $48.95 \%$ & 26 & $9.09 \%$ & 286 & $100.00 \%$ \\
\hline & Other & 12 & $26.09 \%$ & 15 & $32.61 \%$ & 14 & $30.43 \%$ & 5 & $10.87 \%$ & 46 & $100.00 \%$ \\
\hline & $\begin{array}{l}\text { Grand } \\
\text { Total }\end{array}$ & 162 & $26.82 \%$ & 112 & $18.54 \%$ & 266 & $44.04 \%$ & 64 & $10.60 \%$ & 604 & $100.00 \%$ \\
\hline \multirow{4}{*}{ 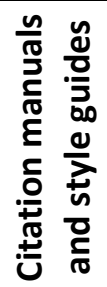 } & Academic & 39 & $14.18 \%$ & 65 & $23.64 \%$ & 156 & $56.73 \%$ & 15 & $5.45 \%$ & 275 & $100.00 \%$ \\
\hline & PhD & 52 & $18.25 \%$ & 38 & $13.33 \%$ & 177 & $62.11 \%$ & 18 & $6.32 \%$ & 285 & $100.00 \%$ \\
\hline & Other & 7 & $15.22 \%$ & 13 & $28.26 \%$ & 21 & $45.65 \%$ & 5 & $10.87 \%$ & 46 & $100.00 \%$ \\
\hline & $\begin{array}{l}\text { Grand } \\
\text { Total }\end{array}$ & 98 & $16.17 \%$ & 116 & $19.14 \%$ & 354 & $58.42 \%$ & 38 & $6.27 \%$ & 606 & $100.00 \%$ \\
\hline
\end{tabular}

\section{Appendix 5. Statistically Significant Format Preferences for Different Types of Book by College Group}

\begin{tabular}{|c|c|c|c|c|c|c|c|c|c|c|c|}
\hline \multirow[b]{2}{*}{$\begin{array}{l}\text { Book } \\
\text { Type }\end{array}$} & \multirow[b]{2}{*}{ College } & \multicolumn{2}{|c|}{ I prefer print } & \multicolumn{2}{|c|}{ No preference } & \multicolumn{2}{|c|}{$\begin{array}{l}\text { I prefer } \\
\text { ebooks }\end{array}$} & \multicolumn{2}{|c|}{ It depends } & \multicolumn{2}{|c|}{ Grand Total } \\
\hline & & Freq. & $\%$ & Freq. & $\%$ & Freq. & $\%$ & Freq. & $\%$ & Freq. & $\%$ \\
\hline \multirow{6}{*}{ 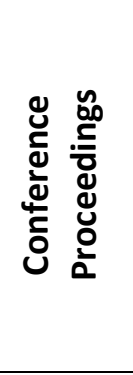 } & Arts & 16 & $15.38 \%$ & 31 & $29.81 \%$ & 48 & $46.15 \%$ & 9 & $8.65 \%$ & 104 & $100.00 \%$ \\
\hline & $\begin{array}{c}\text { Business \& } \\
\quad \text { Law }\end{array}$ & 7 & $9.86 \%$ & 21 & $29.58 \%$ & 39 & $54.93 \%$ & 4 & $5.63 \%$ & 71 & $100.00 \%$ \\
\hline & Education & 17 & $20.24 \%$ & 15 & $17.86 \%$ & 50 & $59.52 \%$ & 2 & $2.38 \%$ & 84 & $100.00 \%$ \\
\hline & Engineering & 21 & $12.73 \%$ & 23 & $13.94 \%$ & 109 & $66.06 \%$ & 12 & $7.27 \%$ & 165 & $100.00 \%$ \\
\hline & Science & 18 & $10.29 \%$ & 46 & $26.29 \%$ & 99 & $56.57 \%$ & 12 & $6.86 \%$ & 175 & $100.00 \%$ \\
\hline & Grand Total & 79 & $13.06 \%$ & 137 & $22.64 \%$ & 348 & $57.52 \%$ & 41 & $6.78 \%$ & 605 & $100.00 \%$ \\
\hline \multirow{6}{*}{ 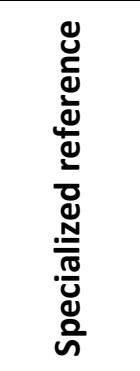 } & Arts & 26 & & & & 45 & $43.69 \%$ & 13 & $12.62 \%$ & 103 & $100.00 \%$ \\
\hline & $\begin{array}{c}\text { Business \& } \\
\text { Law }\end{array}$ & 19 & $27.14 \%$ & 9 & $12.86 \%$ & 38 & $54.29 \%$ & 4 & $5.71 \%$ & 70 & $100.00 \%$ \\
\hline & Education & 33 & $38.82 \%$ & 15 & $17.65 \%$ & 32 & $37.65 \%$ & 5 & $5.88 \%$ & 85 & $100.00 \%$ \\
\hline & Engineering & 39 & $23.49 \%$ & 21 & $12.65 \%$ & 86 & $51.81 \%$ & 20 & $12.05 \%$ & 166 & $100.00 \%$ \\
\hline & Science & 44 & $25.14 \%$ & 48 & $27.43 \%$ & 62 & $35.43 \%$ & 21 & $12.00 \%$ & 175 & $100.00 \%$ \\
\hline & Grand Total & 161 & $26.61 \%$ & 113 & $18.68 \%$ & 266 & $43.97 \%$ & 65 & $10.74 \%$ & 605 & $100.00 \%$ \\
\hline$\frac{n}{\pi} \frac{5}{\pi} \delta$ & Arts & 12 & $11.65 \%$ & 21 & $20.39 \%$ & 63 & $61.17 \%$ & 7 & $6.80 \%$ & 103 & $100.00 \%$ \\
\hline
\end{tabular}




\begin{tabular}{|c|c|c|c|c|c|c|c|c|c|c|c|}
\hline & $\begin{array}{c}\text { Business \& } \\
\text { Law }\end{array}$ & 10 & $14.08 \%$ & 12 & $16.90 \%$ & 48 & $67.61 \%$ & 1 & $1.41 \%$ & 71 & $100.00 \%$ \\
\hline & Education & 23 & $27.06 \%$ & 12 & $14.12 \%$ & 45 & $52.94 \%$ & 5 & $5.88 \%$ & 85 & $100.00 \%$ \\
\hline & Engineering & 26 & $15.66 \%$ & 24 & $14.46 \%$ & 104 & $62.65 \%$ & 12 & $7.23 \%$ & 166 & $100.00 \%$ \\
\hline & Science & 24 & $13.64 \%$ & 47 & $26.70 \%$ & 92 & $52.27 \%$ & 13 & $7.39 \%$ & 176 & $100.00 \%$ \\
\hline & Grand Total & 97 & $15.98 \%$ & 117 & $19.28 \%$ & 354 & $58.32 \%$ & 39 & $6.43 \%$ & 607 & $100.00 \%$ \\
\hline \multirow{6}{*}{ 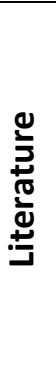 } & Arts & 67 & $65.05 \%$ & 15 & $14.56 \%$ & 14 & $13.59 \%$ & 7 & $6.80 \%$ & 103 & $100.00 \%$ \\
\hline & $\begin{array}{c}\text { Business \& } \\
\text { Law }\end{array}$ & 33 & $46.48 \%$ & 9 & $12.68 \%$ & 21 & $29.58 \%$ & 8 & $11.27 \%$ & 71 & $100.00 \%$ \\
\hline & Education & 55 & $64.71 \%$ & 12 & $14.12 \%$ & 9 & $10.59 \%$ & 9 & $10.59 \%$ & 85 & $100.00 \%$ \\
\hline & Engineering & 83 & $50.00 \%$ & 30 & $18.07 \%$ & 43 & $25.90 \%$ & 10 & $6.02 \%$ & 166 & $100.00 \%$ \\
\hline & Science & 93 & $53.14 \%$ & 34 & $19.43 \%$ & 32 & $18.29 \%$ & 16 & $9.14 \%$ & 175 & $100.00 \%$ \\
\hline & Grand Total & 336 & $55.45 \%$ & 101 & $16.67 \%$ & 119 & $19.64 \%$ & 50 & $8.25 \%$ & 606 & $100.00 \%$ \\
\hline
\end{tabular}

\section{Appendix 6. Importance of Particular Ebook Features}

\begin{tabular}{|c|c|c|c|c|c|c|c|c|c|c|c|c|}
\hline \multirow[b]{2}{*}{ Question } & \multicolumn{2}{|c|}{$\begin{array}{l}\text { Not at all } \\
\text { important }\end{array}$} & \multicolumn{2}{|c|}{$\begin{array}{l}\text { Not very } \\
\text { important }\end{array}$} & \multicolumn{2}{|c|}{ Neutral } & \multicolumn{2}{|c|}{$\begin{array}{l}\text { Somewhat } \\
\text { important }\end{array}$} & \multicolumn{2}{|c|}{$\begin{array}{c}\text { Very } \\
\text { important }\end{array}$} & \multicolumn{2}{|c|}{ Grand Total } \\
\hline & Freq. & $\%$ & Freq. & $\%$ & Freq. & $\%$ & Freq. & $\%$ & Freq. & $\%$ & Freq. & $\%$ \\
\hline $\begin{array}{l}\text { Ability to } \\
\text { find e- } \\
\text { books in } \\
\text { the Library } \\
\text { catalogue } \\
\text { or Library } \\
\text { Search }\end{array}$ & 11 & $1.82 \%$ & 18 & $2.98 \%$ & 38 & $6.29 \%$ & 157 & $25.99 \%$ & 380 & $62.91 \%$ & 604 & $100.00 \%$ \\
\hline $\begin{array}{l}\text { Ability to } \\
\text { find e- } \\
\text { books in } \\
\text { search } \\
\text { engines } \\
\text { (e.g., } \\
\text { Google, } \\
\text { Yahoo) } \\
\end{array}$ & 13 & $2.15 \%$ & 28 & $4.64 \%$ & 72 & $11.92 \%$ & 206 & $34.11 \%$ & 285 & $47.19 \%$ & 604 & $100.00 \%$ \\
\hline $\begin{array}{l}\text { Ability to } \\
\text { download } \\
\text { the whole } \\
\text { e-book to } \\
\text { computer } \\
\text { or laptop } \\
\text { for later } \\
\text { use }\end{array}$ & 7 & $1.16 \%$ & 16 & $2.66 \%$ & 40 & $6.66 \%$ & 152 & $25.29 \%$ & 386 & $64.23 \%$ & 601 & $100.00 \%$ \\
\hline
\end{tabular}




\begin{tabular}{|c|c|c|c|c|c|c|c|c|c|c|c|c|}
\hline $\begin{array}{l}\text { Ability to } \\
\text { download } \\
\text { the book } \\
\text { chapters or } \\
\text { portions of } \\
\text { the e-book } \\
\text { to } \\
\text { computer } \\
\text { or laptop } \\
\text { for later } \\
\text { use }\end{array}$ & 11 & $1.82 \%$ & 14 & $2.31 \%$ & 36 & $5.95 \%$ & 138 & $22.81 \%$ & 406 & $67.11 \%$ & 605 & $100.00 \%$ \\
\hline $\begin{array}{l}\text { Ability to } \\
\text { read on a } \\
\text { mobile } \\
\text { device } \\
\text { (e.g., } \\
\text { iPhone, } \\
\text { iPad, } \\
\text { Blackberry) }\end{array}$ & 99 & $16.39 \%$ & 104 & $17.22 \%$ & 145 & $24.01 \%$ & 145 & $24.01 \%$ & 111 & $18.38 \%$ & 604 & $100.00 \%$ \\
\hline $\begin{array}{l}\text { Ability to } \\
\text { read on a } \\
\text { dedicated } \\
\text { e-book } \\
\text { reader, } \\
\text { (e.g., } \\
\text { Kindle, } \\
\text { Sony } \\
\text { Reader) }\end{array}$ & 140 & $23.14 \%$ & 104 & $17.19 \%$ & 165 & $27.27 \%$ & 123 & $20.33 \%$ & 73 & $12.07 \%$ & 605 & $100.00 \%$ \\
\hline $\begin{array}{c}\text { Ability to } \\
\text { download } \\
\text { the whole } \\
\text { ebook to a } \\
\text { mobile } \\
\text { device }\end{array}$ & 110 & $18.24 \%$ & 121 & $20.07 \%$ & 143 & $23.71 \%$ & 130 & $21.56 \%$ & 99 & $16.42 \%$ & 603 & $100.00 \%$ \\
\hline $\begin{array}{l}\text { Ability to } \\
\text { annotate, } \\
\text { bookmark } \\
\text { or make } \\
\text { notes }\end{array}$ & 34 & $5.68 \%$ & 55 & $9.18 \%$ & 99 & $16.53 \%$ & 193 & $32.22 \%$ & 218 & $36.39 \%$ & 599 & $100.00 \%$ \\
\hline $\begin{array}{l}\text { Ability to } \\
\text { search } \\
\text { within the } \\
\text { full-text of } \\
\text { items }\end{array}$ & 8 & $1.33 \%$ & 11 & $1.82 \%$ & 24 & $3.98 \%$ & 163 & $27.03 \%$ & 397 & $65.84 \%$ & 603 & $100.00 \%$ \\
\hline $\begin{array}{l}\text { Ability to } \\
\text { link to a } \\
\text { particular } \\
\text { chapter }\end{array}$ & 22 & $3.65 \%$ & 32 & $5.32 \%$ & 121 & $20.10 \%$ & 197 & $32.72 \%$ & 230 & $38.21 \%$ & 602 & $100.00 \%$ \\
\hline
\end{tabular}




\begin{tabular}{|c|c|c|c|c|c|c|c|c|c|c|c|c|}
\hline $\begin{array}{l}\text { Availability } \\
\text { of a print } \\
\text { copy of the } \\
\text { same title } \\
\text { from the } \\
\text { Library }\end{array}$ & 40 & $6.62 \%$ & 65 & $10.76 \%$ & 149 & $24.67 \%$ & 161 & $26.66 \%$ & 189 & $31.29 \%$ & 604 & $100.00 \%$ \\
\hline
\end{tabular}

Appendix 7. Opinion of Ebooks

\begin{tabular}{|c|c|c|c|c|c|c|c|c|c|c|c|c|}
\hline \multirow[b]{2}{*}{ Question } & \multicolumn{2}{|c|}{ Strongly agree } & \multicolumn{2}{|c|}{ Agree } & \multicolumn{2}{|c|}{ Neutral } & \multicolumn{2}{|c|}{ Disagree } & \multicolumn{2}{|c|}{$\begin{array}{l}\text { Strongly } \\
\text { disagree }\end{array}$} & \multicolumn{2}{|c|}{ Grand Total } \\
\hline & Freq. & $\%$ & Freq. & $\%$ & Freq. & $\%$ & Freq. & $\%$ & Freq. & $\%$ & Freq. & $\%$ \\
\hline $\begin{array}{c}\text { Ebooks are } \\
\text { as good as } \\
\text { print } \\
\text { books }\end{array}$ & 72 & $11.80 \%$ & 155 & $25.41 \%$ & 156 & $25.57 \%$ & 157 & $25.74 \%$ & 70 & $11.48 \%$ & 610 & $100.00 \%$ \\
\hline $\begin{array}{c}\text { The library } \\
\text { should } \\
\text { continue } \\
\text { to } \\
\text { purchase } \\
\text { books in } \\
\text { print } \\
\text { format } \\
\text { only and } \\
\text { not buy } \\
\text { ebooks }\end{array}$ & 38 & $6.26 \%$ & 46 & $7.58 \%$ & 110 & $18.12 \%$ & 283 & $46.62 \%$ & 130 & $21.42 \%$ & 607 & $100.00 \%$ \\
\hline $\begin{array}{l}\text { The library } \\
\text { should } \\
\text { purchase } \\
\text { book titles } \\
\text { in both } \\
\text { print and } \\
\text { ebook } \\
\text { format }\end{array}$ & 171 & $28.26 \%$ & 257 & $42.48 \%$ & 123 & $20.33 \%$ & 44 & $7.27 \%$ & 10 & $1.65 \%$ & 605 & $100.00 \%$ \\
\hline $\begin{array}{l}\text { The library } \\
\text { should } \\
\text { purchase } \\
\text { book titles } \\
\text { in ebook } \\
\text { format } \\
\text { instead of } \\
\text { print } \\
\text { format }\end{array}$ & 22 & $3.61 \%$ & 74 & $12.15 \%$ & 148 & $24.30 \%$ & 239 & $39.24 \%$ & 126 & $20.69 \%$ & 609 & $100.00 \%$ \\
\hline
\end{tabular}




\begin{tabular}{|c|c|c|c|c|c|c|c|c|c|c|c|c|}
\hline $\begin{array}{c}\text { If } \\
\text { available, I } \\
\text { would } \\
\text { prefer to } \\
\text { use ebooks } \\
\text { as } \\
\text { resources } \\
\text { rather } \\
\text { than print } \\
\text { books for } \\
\text { teaching } \\
\text { or } \\
\text { research }\end{array}$ & 63 & $10.31 \%$ & 162 & $26.51 \%$ & 146 & $23.90 \%$ & 165 & $27.00 \%$ & 75 & $12.27 \%$ & 611 & $100.00 \%$ \\
\hline $\begin{array}{l}\text { Ebooks are } \\
\text { suitable } \\
\text { resources } \\
\text { for my } \\
\text { teaching } \\
\text { and/or } \\
\text { research }\end{array}$ & 107 & $17.66 \%$ & 314 & $51.82 \%$ & 119 & $19.64 \%$ & 43 & $7.10 \%$ & 23 & $3.80 \%$ & 606 & $100.00 \%$ \\
\hline $\begin{array}{l}\text { Ebooks } \\
\text { provided } \\
\text { by the } \\
\text { University } \\
\text { of } \\
\text { Canterbury } \\
\text { Library are } \\
\text { easy to } \\
\text { find }\end{array}$ & 79 & $12.99 \%$ & 249 & $40.95 \%$ & 206 & $33.88 \%$ & 64 & $10.53 \%$ & 10 & $1.64 \%$ & 608 & $100.00 \%$ \\
\hline $\begin{array}{l}\text { Ebooks are } \\
\text { accessible } \\
\text { in the } \\
\text { place(s) } \\
\text { where I } \\
\text { most need } \\
\text { to use } \\
\text { them }\end{array}$ & 61 & $10.08 \%$ & 195 & $32.23 \%$ & 244 & $40.33 \%$ & 85 & $14.05 \%$ & 20 & $3.31 \%$ & 605 & $100.00 \%$ \\
\hline $\begin{array}{c}\text { When } \\
\text { needed, } \\
\text { library } \\
\text { assistance } \\
\text { with using } \\
\text { ebooks is } \\
\text { readily } \\
\text { available }\end{array}$ & 71 & $11.79 \%$ & 184 & $30.56 \%$ & 326 & $54.15 \%$ & 16 & $2.66 \%$ & 5 & $0.83 \%$ & 602 & $100.00 \%$ \\
\hline
\end{tabular}




\section{Appendix 8: Factors Affecting Switching to Ebooks}

\begin{tabular}{|c|c|c|c|c|c|c|c|c|c|c|c|c|c|}
\hline \multicolumn{2}{|c|}{$\begin{array}{l}\text { Factors Affecting Switching to } \\
\text { Ebooks }\end{array}$} & \multicolumn{2}{|c|}{ Strongly agree } & \multicolumn{2}{|c|}{ Agree } & \multicolumn{2}{|c|}{ Neutral } & \multicolumn{2}{|c|}{ Disagree } & \multicolumn{2}{|c|}{$\begin{array}{l}\text { Strongly } \\
\text { disagree }\end{array}$} & \multicolumn{2}{|c|}{ Total } \\
\hline Factors & Statements & Freq. & $\%$ & Freq. & $\%$ & Freq. & $\%$ & Freq. & $\%$ & Freq. & $\%$ & Freq. & $\%$ \\
\hline $\begin{array}{c}\text { Satisfaction } \\
\text { With Print } \\
\text { Books }\end{array}$ & $\begin{array}{c}\text { Using print books } \\
\text { completely satisfies } \\
\text { all my teaching } \\
\text { and/or research } \\
\text { needs } \\
\end{array}$ & 44 & $7.19 \%$ & 144 & $23.53 \%$ & 163 & $26.63 \%$ & 217 & $35.46 \%$ & 44 & $7.19 \%$ & 612 & $100.00 \%$ \\
\hline $\begin{array}{l}\text { Relative } \\
\text { Advantage of } \\
\text { Ebooks }\end{array}$ & $\begin{array}{l}\text { Using an ebook is } \\
\text { more effective than } \\
\text { using a print book } \\
\text { for my teaching } \\
\text { and/or research }\end{array}$ & 41 & $6.72 \%$ & 127 & $20.82 \%$ & 199 & $32.62 \%$ & 181 & $29.67 \%$ & 62 & $10.16 \%$ & 610 & $100.00 \%$ \\
\hline Switching Cost & $\begin{array}{l}\text { Learning how to use } \\
\text { ebooks takes a lot } \\
\text { of time and effort }\end{array}$ & 12 & $1.97 \%$ & 52 & $8.54 \%$ & 137 & $22.50 \%$ & 301 & $49.43 \%$ & 107 & $17.57 \%$ & 609 & $100.00 \%$ \\
\hline $\begin{array}{c}\text { Personal } \\
\text { Innovativenes } \\
\text { s With IT }\end{array}$ & $\begin{array}{l}\text { I like to experiment } \\
\text { with new } \\
\text { information } \\
\text { technology }\end{array}$ & 107 & $17.69 \%$ & 312 & $51.57 \%$ & 135 & $22.31 \%$ & 43 & $7.11 \%$ & 8 & $1.32 \%$ & 605 & $100.00 \%$ \\
\hline $\begin{array}{c}\text { Subjective } \\
\text { Norm Toward } \\
\text { Switching to } \\
\text { Ebooks }\end{array}$ & $\begin{array}{l}\text { People I respect } \\
\text { think that I should } \\
\text { switch from print } \\
\text { books to ebooks }\end{array}$ & 9 & $1.49 \%$ & 42 & $6.94 \%$ & 324 & $53.55 \%$ & 158 & $26.12 \%$ & 72 & $11.90 \%$ & 605 & $100.00 \%$ \\
\hline $\begin{array}{l}\text { Switching to } \\
\text { Ebook } \\
\text { Intention }\end{array}$ & $\begin{array}{l}\text { I intend to increase } \\
\text { my use of ebooks }\end{array}$ & 44 & $7.20 \%$ & 272 & $44.52 \%$ & 215 & $35.19 \%$ & 58 & $9.49 \%$ & 22 & $3.60 \%$ & 611 & $100.00 \%$ \\
\hline
\end{tabular}

\section{Appendix 9: Survey Questions}

Q20 Participant Consent Below we ask you to give us your consent to use your data for this research. Please indicate if you would like additional details about the survey first.

Yes I would like additional information (1)

No I don't need additional information (2)

\footnotetext{
Answer If Participant Consent Below we ask you to give us your consent to use your data for this research. If you would like additional details about that prior to giving consent please check here. Yes I would like additional information Is Selected

Info Participant Information Sheet Research Project Title: Attitudes towards and use of Ebooks at the University of Canterbury Researcher: Nick Scullin, School of Information Management, Victoria University of Wellington As part of the completion of my Master of Information Studies, this survey is designed to investigate attitudes towards and use of ebooks by academic staff members and PhD students at the University of Canterbury. In addition to studying at Victoria University I am also a
} 
Librarian at the University of Canterbury, based in the Education Library. This study will seek to build on previous studies that have investigated ebook usage in academic contexts in order to add to the international body of knowledge around perceptions of and use of ebooks in academic libraries. Additionally the study also hopes to inform the University of Canterbury Library with regard to its ebook collections and policies and procedures for purchasing ebooks. With a better understanding of how ebooks are perceived and used it is hoped that the library will be able to better meet the needs of its users with regard to the provision of ebooks. Victoria University requires, and has granted, approval from the School of Information Management Human Ethics Committee. This approval has been forwarded to the Chair of the University of Canterbury Human Ethics Committee. Additionally, the University of Canterbury Survey Reference Group has also granted permission for the survey to be conducted. The survey is being conducted on my behalf by the University of Canterbury Surveys Coordinator who will provide an anonymous data set to me that does not include any participant contact details. I am inviting academic staff and PhD students of the University of Canterbury to participate in this research. Participants will be asked to fill in an anonymous short online survey about their attitudes towards and use of ebooks. No details that could identify participants will be collected in the survey. At the end of the survey participants will have the option of entering a prize draw for a $\$ 25.00$ Westfield gift card. The University of Canterbury Surveys Coordinator will supply the email address of the winner of the prize draw to the researcher. All data collected will be stored securely on the University of Canterbury's Qualtrics software servers. Participation is voluntary and as the survey is anonymous you will not be identified personally in any written report produced as a result of this research, including possible publication in academic conferences and journals. All material collected will be kept confidential, and will be viewed only by myself and my supervisor Dr Brenda Chawner, Senior Lecturer, School of Information Management, Victoria University of Wellington. The research report will be submitted for marking to the School of Information Management, and subsequently deposited in the Victoria University of Wellington Research Archive. All data collected from participants will be destroyed within 2 years after the completion of the project. If you have any questions or would like to receive further information about the project, please contact me at scullinico@myvuw.ac.nz or telephone 022045 0391, or you may contact my supervisor Dr Brenda Chawner, Senior Lecturer, School of Information Management, Victoria University of Wellington at brenda.chawner@vuw.ac.nz or telephone (04) 4635780 . Yours Sincerely Nick Scullin

Consent Participant Consent I have had the opportunity to request explanation of this research project. I understand that any information I provide will be anonymous and viewed only by the researcher and their supervisor. I understand that the data I provide will not be used for any other purpose or released to others. I understand that the data I provide will be destroyed within 2 years after the completion of the project. By clicking the next arrow ( >>) I agree to the above points. 
Q0 How old are you?

O $20-29(1)$

O $30-39$ (2)

O $40-49(3)$

O $50+(4)$

O I'd rather not say (5)

Q1 Are you?

O Female (1)

O Male (2)

O I'd rather not say (3)

Other (please specify) (4)

Q2 Are you a PhD student or an academic staff member?

O PhD Student (1)

O Academic staff member (2)

O Other (3)

Q3 With which college are you mainly affiliated in terms of your job or study?

College of Arts (1)

O College of Business and Law (2)

College of Education (5)

College of Engineering (3)

O College of Science (4)

Other (8)

Q4 Are you aware that the University of Canterbury Library provides access to ebooks?

Y Yes (1)

O No (2)

If No Is Selected, Then Skip To I have used an ebook relevant to my p...

Q5 Have you used an ebook provided by the University of Canterbury Library?

Once (1)

A couple of times (2)

O Often (3)

O Never (4) 
Q6 Of the books you want to read what format are they usually available in?

Print only (1)

O Print and ebook (2)

Obook only (3)

Q7 Approximately what percentage of the University of Canterbury Library print book collection do you think is also available to you as an ebook in the university Library or somewhere else?

O $0 \%-19 \%(1)$

O $20 \%-39 \%(2)$

O $40 \%-59 \%(3)$

O $60 \%-79 \%(4)$

O $80 \%-100(5)$

Q8 Have you used an ebook relevant to your primary subject area?

Yes (1)

O No (2)

I I have not searched (3) 
Q9 In the following question the formats are defined as follows: Scholarly monograph: Book-length, detailed study of a single subject, usually by a single author. Edited collection: Book on a single theme with one or more editors and chapters/essays on different subjects by different authors. Conference proceedings: A published collection of papers presented at an conference. General reference: Examples: Oxford English Dictionary, Encyclopædia Britannica, World Almanac, Bartlett's Quotations, etc. Specialized reference: Examples: subject encyclopedias (e.g., Oxford Encyclopedia of Economic History), research guides (e.g., Literary Research Guide), handbooks and manuals (e.g., Merck Manuals), etc. Citation manuals and style guides: Examples: Chicago Manual of Style, MLA Handbook, APA Publication Manual, etc. Literature: Novels, short stories, poetry, etc. Please indicate in what format you would prefer that the University of Canterbury Library purchase the following types of resources:

\begin{tabular}{|c|c|c|c|c|}
\hline $\begin{array}{c}\text { Scholarly } \\
\text { monographs (1) }\end{array}$ & I Prefer Print (1) & No Preference (2) & I Prefer Ebooks (3) & It Depends (4) \\
$\begin{array}{c}\text { Edited collections } \\
\text { (2) }\end{array}$ & 0 & 0 & 0 & 0 \\
$\begin{array}{c}\text { Conference } \\
\text { proceedings (3) }\end{array}$ & 0 & 0 & 0 & 0 \\
$\begin{array}{c}\text { General reference } \\
\text { (4) }\end{array}$ & 0 & 0 & 0 & 0 \\
$\begin{array}{c}\text { Specialized } \\
\text { reference (5) } \\
\text { Citation manuals } \\
\text { and style guides (6) } \\
\text { Literature (7) }\end{array}$ & 0 & 0 & 0 & 0 \\
\hline
\end{tabular}


Q10 When doing your academic work, how important are the following features:(If you have never used an ebook, how important would these features be if considering using one.)

\begin{tabular}{|c|c|c|c|c|c|}
\hline & $\begin{array}{c}\text { Not at all } \\
\text { Important (1) }\end{array}$ & $\begin{array}{c}\text { Not very } \\
\text { Important (2) }\end{array}$ & Neutral (3) & $\begin{array}{l}\text { Somewhat } \\
\text { Important (4) }\end{array}$ & $\begin{array}{c}\text { Very Important } \\
\text { (5) }\end{array}$ \\
\hline $\begin{array}{l}\text { Ability to find e- } \\
\text { books in the } \\
\text { Library } \\
\text { catalogue or } \\
\text { Library Search } \\
\text { (1) }\end{array}$ & $\mathrm{O}$ & 0 & $\mathrm{O}$ & $\mathrm{O}$ & 0 \\
\hline $\begin{array}{l}\text { Ability to find e- } \\
\text { books in search } \\
\text { engines (e.g., } \\
\text { Google, Yahoo) } \\
\text { (2) }\end{array}$ & 0 & $\mathrm{O}$ & 0 & $\mathrm{O}$ & $\mathrm{O}$ \\
\hline $\begin{array}{c}\text { Ability to } \\
\text { download the } \\
\text { whole e-book } \\
\text { to computer or } \\
\text { laptop for later } \\
\text { use (3) }\end{array}$ & 0 & 0 & 0 & 0 & O \\
\hline $\begin{array}{c}\text { Ability to } \\
\text { download the } \\
\text { book chapters } \\
\text { or portions of } \\
\text { the e-book to } \\
\text { computer or } \\
\text { laptop for later } \\
\text { use (4) }\end{array}$ & 0 & $\mathrm{O}$ & 0 & O & 0 \\
\hline $\begin{array}{l}\text { Ability to read } \\
\text { on a mobile } \\
\text { device (e.g., } \\
\text { iPhone, iPad, } \\
\text { Blackberry) (5) }\end{array}$ & 0 & $\mathrm{O}$ & 0 & 0 & 0 \\
\hline $\begin{array}{c}\text { Ability to read } \\
\text { on a dedicated } \\
\text { e-book reader, } \\
\text { (e.g., Kindle, } \\
\text { Sony Reader) } \\
\text { (6) }\end{array}$ & 0 & $\mathrm{O}$ & 0 & O & $\mathrm{O}$ \\
\hline $\begin{array}{c}\text { Ability to } \\
\text { download the } \\
\text { whole ebook to } \\
\text { a mobile device } \\
\text { (7) }\end{array}$ & 0 & 0 & 0 & 0 & 0 \\
\hline $\begin{array}{c}\text { Ability to } \\
\text { annotate, } \\
\text { bookmark or } \\
\text { make notes (8) }\end{array}$ & 0 & 0 & 0 & O & 0 \\
\hline $\begin{array}{l}\text { Ability to search } \\
\text { within the full- }\end{array}$ & 0 & $\mathrm{O}$ & O & 0 & O \\
\hline
\end{tabular}




\begin{tabular}{|c|c|c|c|c|c|}
\hline $\begin{array}{c}\text { text of items (9) } \\
\text { Ability to link to } \\
\text { a particular } \\
\text { chapter (10) }\end{array}$ & 0 & 0 & 0 & 0 & 0 \\
$\begin{array}{c}\text { Availability of a } \\
\text { print copy of } \\
\text { the same title } \\
\text { from the Library } \\
(11)\end{array}$ & 0 & 0 & 0 & 0 & 0 \\
\hline
\end{tabular}


Q11 Select your response to the statements using the following scale:

\begin{tabular}{|c|c|c|c|c|c|}
\hline & $\begin{array}{c}\text { Strongly Agree } \\
\text { (1) }\end{array}$ & Agree (2) & Neutral (3) & Disagree (4) & $\begin{array}{c}\text { Strongly } \\
\text { Disagree (5) }\end{array}$ \\
\hline $\begin{array}{c}\text { Ebooks are as } \\
\text { good as print } \\
\text { books (1) }\end{array}$ & $\mathrm{O}$ & O & O & $\mathrm{O}$ & $\mathrm{O}$ \\
\hline $\begin{array}{l}\text { The library } \\
\text { should continue } \\
\text { to purchase } \\
\text { books in print } \\
\text { format only and } \\
\text { not buy ebooks } \\
\text { (2) }\end{array}$ & $\mathrm{O}$ & O & $\mathrm{O}$ & O & 0 \\
\hline $\begin{array}{l}\text { The library } \\
\text { should } \\
\text { purchase book } \\
\text { titles in both } \\
\text { print and ebook } \\
\text { format (3) }\end{array}$ & $\mathrm{O}$ & 0 & $\mathrm{O}$ & 0 & 0 \\
\hline $\begin{array}{l}\text { The library } \\
\text { should } \\
\text { purchase book } \\
\text { titles in ebook } \\
\text { format instead } \\
\text { of print format } \\
\text { (4) }\end{array}$ & $\mathrm{O}$ & O & $\mathrm{O}$ & O & O \\
\hline $\begin{array}{l}\text { If available, I } \\
\text { would prefer to } \\
\text { use ebooks as } \\
\text { resources } \\
\text { rather than } \\
\text { print books for } \\
\text { teaching or } \\
\text { research (5) }\end{array}$ & $\mathrm{O}$ & 0 & 0 & 0 & 0 \\
\hline $\begin{array}{l}\text { Ebooks are } \\
\text { suitable } \\
\text { resources for } \\
\text { my teaching } \\
\text { and/or research } \\
\text { (6) }\end{array}$ & $\mathrm{O}$ & 0 & 0 & 0 & 0 \\
\hline $\begin{array}{l}\text { Ebooks } \\
\text { provided by the } \\
\text { University of } \\
\text { Canterbury } \\
\text { Library are easy } \\
\text { to find (7) }\end{array}$ & 0 & 0 & O & $\mathrm{O}$ & 0 \\
\hline $\begin{array}{l}\text { Ebooks are } \\
\text { accessible in } \\
\text { the place(s) } \\
\text { where I most } \\
\text { need to use }\end{array}$ & $\mathrm{O}$ & 0 & 0 & O & 0 \\
\hline
\end{tabular}




\begin{tabular}{|c|c|c|c|c|c|}
\hline $\begin{array}{c}\text { them (8) } \\
\text { When needed, } \\
\text { library } \\
\text { assistance with }\end{array}$ & 0 & 0 & 0 & 0 & 0 \\
$\begin{array}{c}\text { using ebooks is } \\
\text { readily available } \\
\text { (9) }\end{array}$ & & 0 & & \\
\hline
\end{tabular}

Q12 Which of the following would make ebooks more suitable for use in your subject area for teaching and/or research?(select all that apply)

Greater breadth and depth of collection (1)

Ability to download (2)

Less restrictions on printing and copying (3)

More current titles (4)

Better training and instruction (5)

Multi-user access (6)

Better research tools (e.g., annotation) (7)

Multimedia capabilities (8)

Mobile device accessibility (9)

- Other (please explain) (10) 
Q13 Select your response to the statements below using the following scale:

\begin{tabular}{|c|c|c|c|c|c|}
\hline & $\begin{array}{l}\text { Strongly Agree } \\
\text { (1) }\end{array}$ & Agree (2) & Neutral (3) & Disagree (4) & $\begin{array}{c}\text { Strongly } \\
\text { Disagree (5) }\end{array}$ \\
\hline $\begin{array}{l}\text { Using print } \\
\text { books } \\
\text { completely } \\
\text { satisfies all my } \\
\text { teaching and/or } \\
\text { research needs } \\
\text { (1) }\end{array}$ & O & $\mathrm{O}$ & $\mathrm{O}$ & O & O \\
\hline $\begin{array}{l}\text { Using an ebook } \\
\text { is more } \\
\text { effective than } \\
\text { using a print } \\
\text { book for my } \\
\text { teaching and/or } \\
\text { research (2) }\end{array}$ & O & O & O & O & O \\
\hline $\begin{array}{l}\text { Learning how to } \\
\text { use ebooks } \\
\text { takes a lot of } \\
\text { time and effort } \\
\text { (3) }\end{array}$ & O & 0 & 0 & O & 0 \\
\hline $\begin{array}{c}\text { I like to } \\
\text { experiment } \\
\text { with new } \\
\text { information } \\
\text { technology (4) }\end{array}$ & $\mathrm{O}$ & $\mathrm{O}$ & $\mathrm{O}$ & O & $\mathrm{O}$ \\
\hline $\begin{array}{l}\text { People I respect } \\
\text { think that I } \\
\text { should switch } \\
\text { from print } \\
\text { books to ebooks } \\
\text { (5) }\end{array}$ & 0 & 0 & O & O & $\mathrm{O}$ \\
\hline $\begin{array}{l}\text { I intend to } \\
\text { increase my use } \\
\text { of ebooks (6) }\end{array}$ & O & $\mathrm{O}$ & O & O & 0 \\
\hline
\end{tabular}

Q14 Please add any other comments you may have about your use of ebooks in the box below.

Q15 I would like to enter the prize draw for a $\$ 25.00$ Westfield gift card.

Yes (1)

O No (2) 